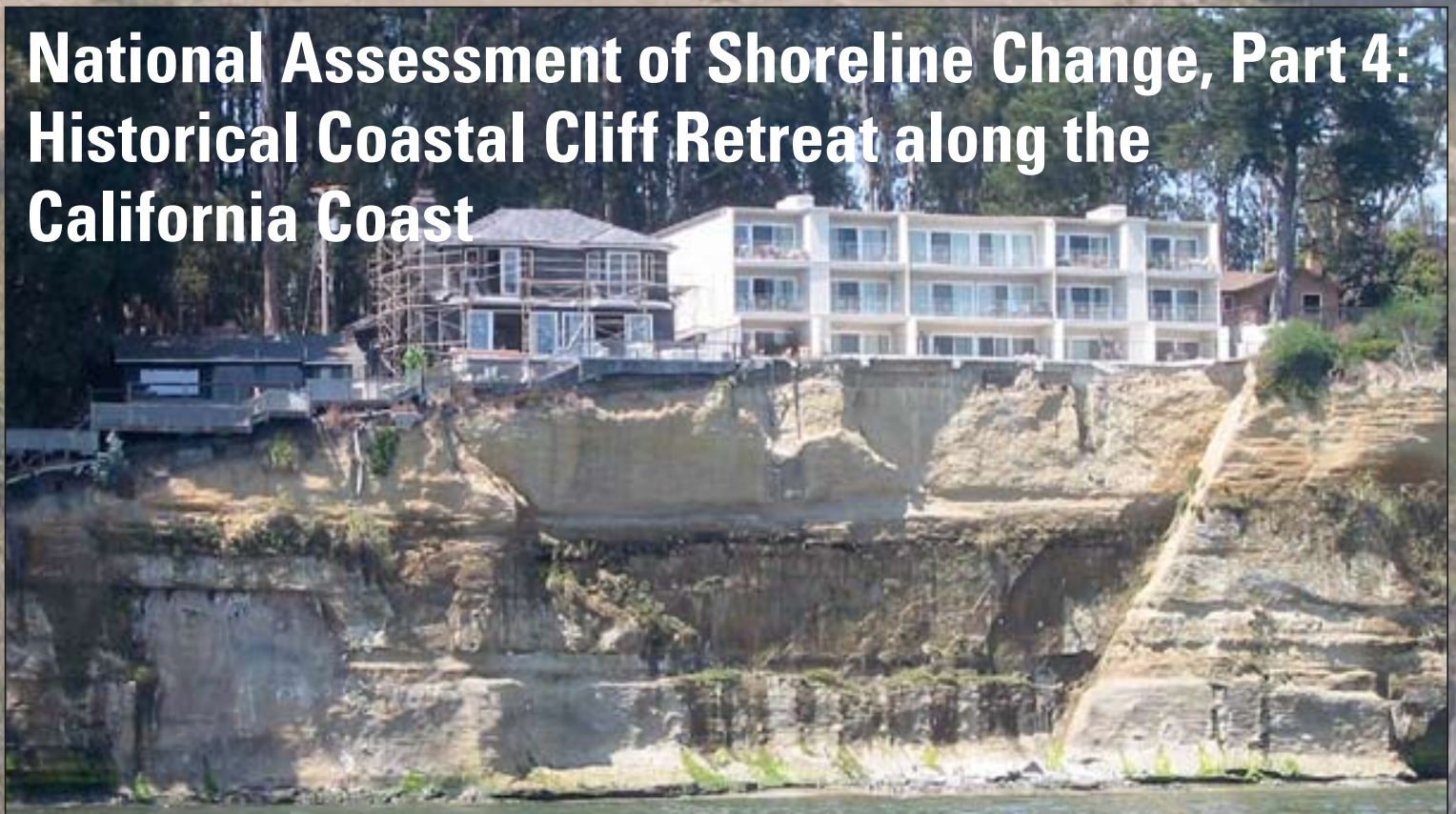

Cheryl J. Hapke and David Reid

Qpen-File Report 2007-1133 U.S. Department of the Interior U:S. Geological Survey 


\section{National Assessment of Shoreline Change, Part 4: Historical Coastal Cliff Retreat along the California Coast}

Cheryl J. Hapke' and David Reid ${ }^{2}$

Open File Report 2007-1133

'U.S. Geological Survey, Patuxent Wildlife Science Center, Coastal Field Station, Department of Geosciences, University of Rhode Island, Kingston, RI 02881

${ }^{2}$ U.S. Geological Survey, Pacific Science Center, 400 Natural Bridges Drive, Santa Cruz, CA 95060

This report is preliminary and has not been reviewed for conformity with U.S. Geological Survey editorial standards. Any use of trade, firm, or product names is for descriptive purposes only and does not imply endorsement by the U.S. Government. 


\section{Contents}

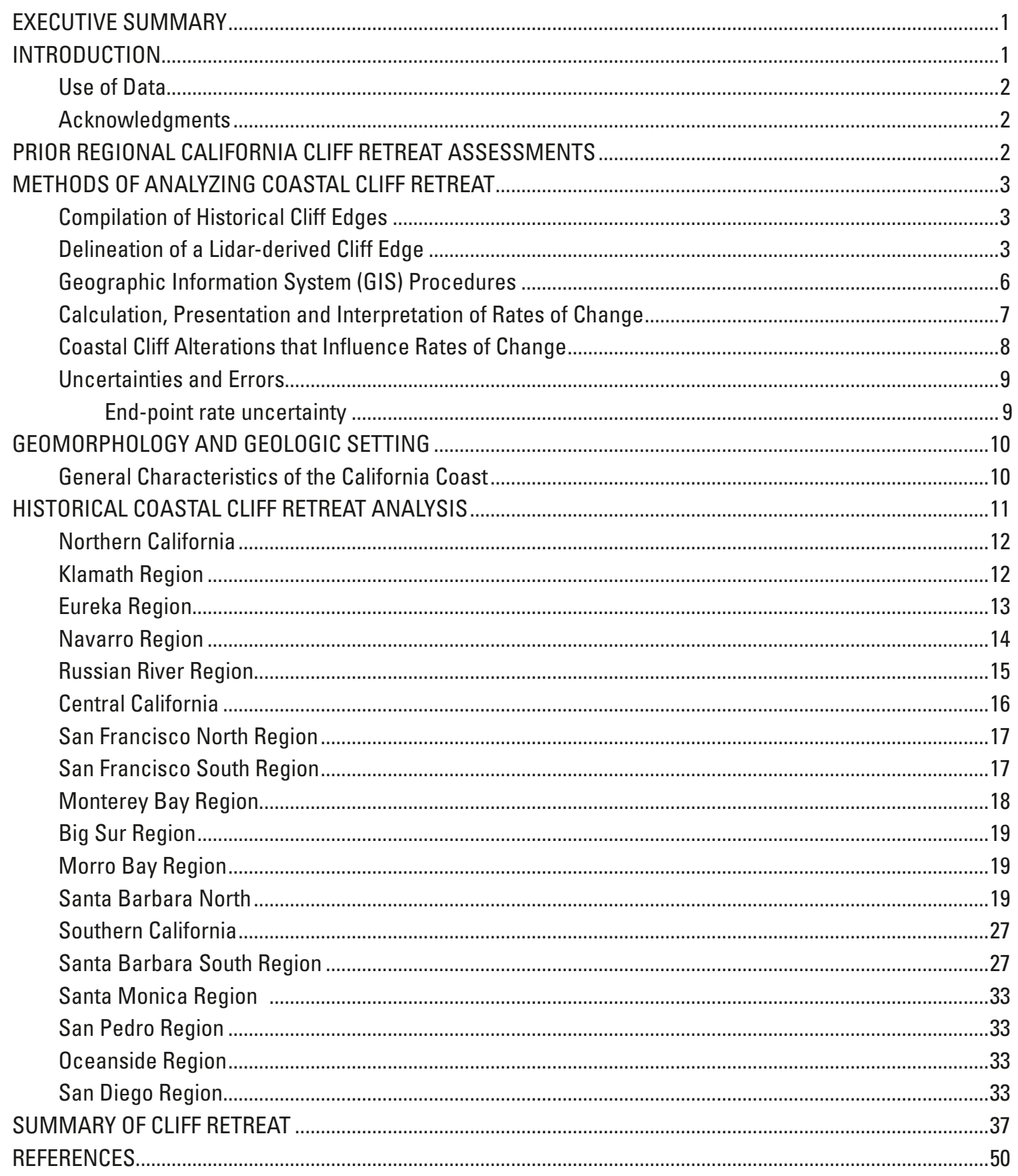




\section{Figures}

Figure 1. Oblique aerial photograph of cliffs at La Jolla and hillshade of lidar data of the same area .............................

Figure 2. Slope image derived from lidar data of the same general area as shown in Figure 1......................................5

Figure 3. There is development both on top of the marine terrace and at the base of the cliff in Northern Monterey Bay.

Figure 4. Big Sur coastline where a distinct cliff edge can be difficult to interpret or define .........................................6

Figure 5. A stretch of coast in Malibu where it is possible to interpret two cliff edges in the same location....................7

Figure 6. Schematic diagram showing required transect edits that are common on crenulated coastlines .....................8

Figure 7. Simplified geologic map of California..........................................................................................................

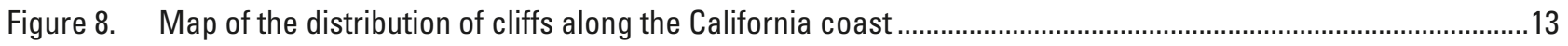

Figure 9. Index map of California showing the relative locations of the fifteen analysis regions.......................................14

Figure 10A. Index map of Northern California showing the four analysis regions and specific locations of geographic places discussed in the text.

Figure 10B. Index map of Central California showing the six analysis regions and specific locations of geographic places discussed in the text.

Figure 10C. Index map of Southern California showing the five analysis regions and specific locations of geographic places discussed in the text.

Figure 11. Cliff retreat rates and spatial distribution of rates for the Klamath region ..........................................................20

Figure 12. Photographs of regions of high cliff retreat in the Klamath region ...................................................................21

Figure 13. Cliff retreat rates and spatial distribution of rates for the Eureka region. ...........................................................22

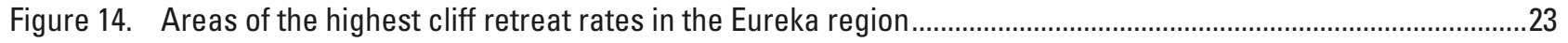

Figure 15. Cliff retreat rates and spatial distribution of rates for the Navarro region ............................................................24

Figure 16. The highest rate in the state was measured at this location on the south end of Rockport Beach near Cape Vizcaino

Figure 17. Cliff retreat rates and spatial distribution of rates for the Russian River region ...............................................26

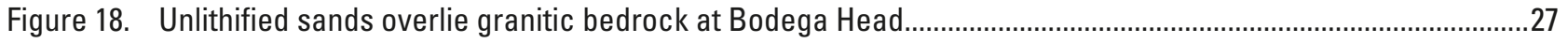

Figure 19. Cliff retreat rates and spatial distribution of rates for the San Francisco North region....................................28

Figure 20. Poorly lithified marine sediments overlie granitic and metamorphic rocks at Point Reyes ............................29

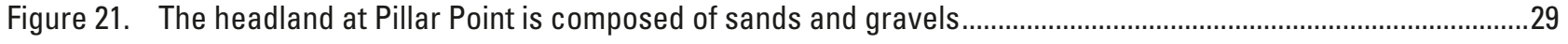

Figure 22. Cliff retreat rates and spatial distribution of rates for the San Francisco South region ...................................30

Figure 23. Cliff retreat rates and spatial distribution of rates for the Monterey Bay region ...............................................31

Figure 24. Stillwell Hall, a soldier's club on the Fort Ord military base, was threatened by rapid erosion of the bluffs for years before being removed in 2004

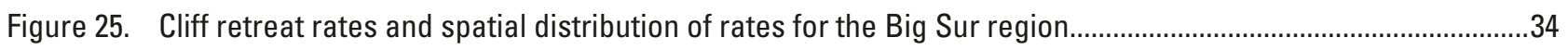

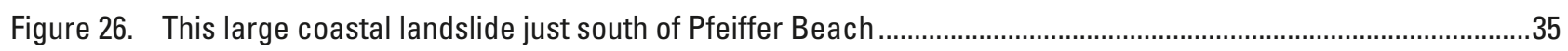

Figure 27. Cliff retreat rates and spatial distribution of rates for the Morro Bay region......................................................36

Figure 28. Retreat of the low coastal cliff threatens these homes near Cayucos Beach....................................................37

Figure 29. Cliff retreat rates and spatial distribution of rates for the Santa Barbara North region.....................................38 


\section{Figures continued}

Figure 30. Bluffs formed in Quaternary sands at Point Sal had the highest retreat rates in the Santa Barbara North region

Figure 31. Cliff retreat rates and spatial distribution of rates for the Santa Barbara South region

Figure 32. The cliffs at Arroyo Burro (Hendry's) Beach have the highest erosion rates in the Santa Barbara South region

Figure 33. Cliff retreat rates and spatial distribution of rates for the Santa Monica region................................................42

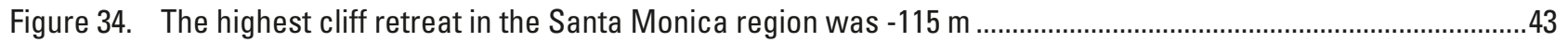

Figure 35. Cliff retreat rates and spatial distribution of rates for the San Pedro region .......................................................44

Figure 36. The highest retreat rates in the San Pedro region were measured at the site of the Sunken City landslide at Point Fermin.

Figure 37. Cliff retreat rates and spatial distribution of rates for the 0 ceanside region.......................................................46

Figure 38. The cliffs at San Onofre Beach have the highest erosion rates in the Oceanside region, and the cliffs at Torrey Pines City Beach have eroded nearly $100 \mathrm{~m}$

Figure 39. Cliff retreat rates and spatial distribution of rates for the San Diego region

Figure 40. The maximum cliff retreat $(-100 \mathrm{~m})$ and the highest retreat rate $(-1.6 \mathrm{~m} / \mathrm{yr})$ in the San Diego region were measured at the site of the Point Loma Nazarine College. 


\section{Tables}

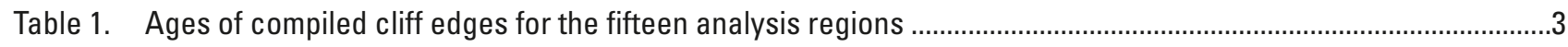

Table 2. Estimated positional uncertainties for California cliff edges..................................................................................

Table 3. Coastal cliff rock and sediment types along the California coast....................................................................12

Table 4. Number of transects, coastal extents and average cliff retreat rates for California ...........................................18

Table 5. Maximum cliff retreat rates and locations of maximums for the fifteen analysis regions. ...................................19 


\section{EXECUTIVE SUMMARY}

Coastal cliff retreat, the landward migration of the cliff face, is a chronic problem along many rocky coastlines in the United States. As coastal populations continue to grow and community infrastructures are threatened by erosion, there is increased demand for accurate information regarding trends and rates of coastal cliff retreat. There is also a need for a comprehensive analysis of cliff retreat that is consistent from one coastal region to another. To meet these national needs, the U.S. Geological Survey is conducting an analysis of historical coastal cliff retreat along open-ocean rocky coastlines of the conterminous United States and parts of Hawaii, Alaska, and the Great Lakes. One purpose of this work is to develop standard repeatable methods for mapping and analyzing coastal cliff retreat so that periodic updates of coastal erosion can be made nationally that are systematic and internally consistent.

This report on the California Coast is an accompaniment to a report on long-term sandy shoreline change for California. This report summarizes the methods of analysis, interprets the results, and provides explanations regarding long-term rates of cliff retreat. Neither detailed background information on the National Assessment of Shoreline Change Project nor detailed descriptions of the geology and geomorphology of the California coastline are presented in this report. The reader is referred to the shoreline change report (Hapke et al., 2006) for this type of background information.

Cliff retreat evaluations are based on comparing one historical cliff edge digitized from maps, with a recent cliff edge interpreted from lidar (Light Detection and Ranging) topographic surveys. The historical cliff edges are from a period ranging from 1920-1930, whereas the lidar cliff edges are from either 1998 or 2002 . Long-term ( 70-year) rates of retreat are calculated using the two cliff edges. The rates of retreat presented in this report represent conditions from the 1930s to 1998, and are not intended for predicting future cliff edge positions or rates of retreat. Due to the geomorphology of much of California's rocky coast (high-relief, steep slopes with no defined cliff edge) as well as to gaps in both the historical maps and lidar data, we were able to derive two cliff edges and therefore calculate cliff retreat rates for a total of $353 \mathrm{~km}$.

The average rate of coastal cliff retreat for the State of California was $-0.3 \pm 0.2 \mathrm{~m} / \mathrm{yr}$, based on rates averaged from 17,653 individual transects measured throughout all areas of California's rocky coastline. The average amount of cliff retreat was $17.7 \mathrm{~m}$ over the 70-year time period of our analysis. Retreat rates were generally lowest in Southern California where coastal engineering projects have greatly altered the natural coastal system. California permits shoreline stabilization structures where homes, buildings or other community infrastructure are imminently threatened by erosion. While seawalls and/or riprap revetments have been constructed in all three sections of California, a larger proportion of the Southern California coast has been protected by engineering works, due, in part, to the larger population pressures in this area.

\section{INTRODUCTION}

According to Griggs and Patsch (2004) 72\%, or 1300 $\mathrm{km}$, of the California coast has eroding coastal cliffs. The retreat of these cliffs results in land loss and damage to private and community properties. Besides being popular tourist and recreation locales, the coastal cliff environments of California constitute some of the most valuable real estate in the country. Because these coasts play such an important role to California's tourist industry and residential development, the U.S. Geological Survey (USGS) is conducting a National Assessment of Coastal Change Hazards. One component of this effort, the National Assessment of Shoreline Change, documents changes in shoreline position as a proxy for coastal change (Morton et al., 2004; Morton and Miller, 2005; Hapke et al., 2006). In the case of this analysis, the coastal change being assessed is the upper edge of the coastal cliff, a commonly used indicator of coastal cliff retreat. The cliff top is used instead of the base for several reasons, including a) the base is sometimes obscured by shadowing in our data sources, b) the cliff base is irregularly interpreted on the historical maps used in the study, and c) emplacement of seawalls and revetment, some of which may not be identifiable on the lidar data, can result in apparent accretion of a cliff base.

A principal purpose of the USGS coastal change research is to develop repeatable methodologies for measuring change so coastlines of the continental U.S., and portions of Hawaii and Alaska, can be periodically and systematically updated in an internally consistent manner. The primary objectives of this effort are: (1) to develop and implement consistent and regionally applicable methods of assessing and monitoring coastal cliff retreat, (2) to obtain a better understanding of the processes that control retreat, and (3) to enter into partnerships to facilitate data dissemination.

Until now, no systematic consistent methodology has existed to address regional coastal cliff retreat, and very few data sets provide sufficient regional historical coverage. Traditionally, aerial photography has provided the most extensive datasets and has been used to derive two or more dates of cliff edges for retreat analyses. However, it is generally difficult to interpret the edge from 2D orthophotographs or georeferenced imagery. Visualization in 3D using photogrammetric techniques is therefore favorable for identifying the true break in slope at the cliff crest, but this technique is costly and time consuming. Additionally, historical aerial photographs are 
not always widely available and can be difficult to acquire and process for regional scale assessments. On the other hand, aerial-based lidar datasets are now becoming available and provide a consistent topographic model from which a cliff edge may be derived. However, because it is a relatively new technology as applied to coastal mapping, there is no historical data with which to make comparisons. To address this issue, historical maps were used as a base for comparison. The maps provide the oldest, continuous regional dataset along the California coast for which a cliff edge can be derived.

This report summarizes regional historical changes along California's coastal cliffs. The descriptions of coastal land loss for each region within the state provide a more comprehensive view of coastal cliff processes and provide key references that can be used to learn more about coastal change in a regional context.

Coastal cliff retreat hazards are not restricted to California. The USGS will undertake similar, systematic analyses of cliff retreat in other states including the Pacific Northwest, New England and Great Lakes coastlines.

\section{Use of Data}

Results of the National Assessment of Shoreline Change and Cliff Retreat are organized by coastal regions. This addendum report for California is part of a series of reports that will include text summarizing methods, results, and implications of the results in addition to maps, via Internet Map Server (IMS), illustrating rates of coastal change. Rates of change are being published for the purpose of regional characterization. The results and products prepared by the USGS are not intended for comprehensive detailed site specific analysis of cliff retreat, nor are they intended to replace any official sources of cliff erosion information identified by local or state government agencies, or other federal entities that are used for regulatory purposes. Retreat rates presented herein may differ from other published rates, and differences do not necessarily indicate that the other rates are inaccurate. Some discrepancies are expected, considering the many possible ways of determining cliff edge positions and rates of change, and the inherent uncertainty in calculating these rates. Rates presented in this report represent cliff retreat under past conditions. The results are not intended for predicting future cliff edge positions or future rates of cliff retreat.

Although the data in this report have been subjected to rigorous review and are substantially complete, the USGS reserves the right to revise the data pursuant to further analysis and review. Furthermore, the data are released on the condition that neither the USGS nor the United States Government may be held liable for any dangers resulting from authorized or unauthorized use of the data.

\section{Acknowledgments}

This report was made possible by the hard work and generous cooperation of many individuals. Brian Spear (UCSC) provided tremendous assistance by digitizing cliff edges and georeferencing historical maps. Krystal Green (USGS) was indispensable for her time for gridding the lidar data and creating the hillshade images. Mark Borrelli (URI) prepared the data for analysis and compiled all the metadata. We owe a debt of gratitude to Mike Rink (NOAA) and Paul Frascione (Information Manufacturing Corporation) for providing digital scans of selected T-sheets, and David Doyle (NOAA) for providing datum corrections so that T-sheets could be rectified before they were digitized by the USGS. Rob Thieler worked closely with TPMC Environmental Services to develop and improve the Digital Shoreline Analysis System (DSAS) code for coastal change measurement. The photograph on the cover was taken by Bruce Richmond (USGS).

\section{PRIOR REGIONAL CALIFORNIA CLIFF RETREAT ASSESSMENTS}

There are few studies of regional coastal cliff erosion for California. The USACE (1971) conducted the first national assessment of coastal erosion that included California. That study identified areas of critical and non-critical erosion on the basis of economic development and potential for property loss, but specific rates of cliff retreat were not quantified. Numerous analyses have been conducted for specific sites by private contractors, cities and counties where erosion rates have been required for regulatory or management purposes. Some of these analyses were incorporated into Dolan and others (1985), and Griggs and Savoy (1985), where rates of change were presented on maps and the long-term trends of erosion were summarized in an accompanying text. The Griggs and Savoy (1985) compilation has recently been updated (Griggs et al., 2005), and most of the erosion hazards addressed therein pertain to coastal cliff erosion, with the exception of Southern California. These compilations rely on existing data and erosion rates calculated using different methods, and therefore the results from one section of coast to the next cannot be validly compared. The most regionally comprehensive modern cliff retreat analysis is presented by Moore et al. (1999), where retreat rates were determined for two counties in California: Santa Cruz and San Diego. This analysis used digital photogrammetric techniques wherein the cliff edge is digitized while viewing in 3D. Even more recently, airborne and ground-based lidar has been used to map coastal cliffs at high resolution and measure short-term cliff retreat in California (Sallenger et al., 2002; Collins and Sitar, 2004; Young and Ashford, 2006). Whereas these methods can be 
accurate and precise, the analyses lack a historical component, simply due to the youth of the technology.

Although numerous analyses of cliff retreat have been conducted throughout the coastal U.S., there remains a critical need for (1) a nationwide compilation of reliable cliff retreat data including the most recent cliff-edge position, and (2) a standardization of methods for obtaining and comparing cliff positions and mathematically analyzing the trends.

\section{METHODS OF ANALYZING COASTAL CLIFF RETREAT}

\section{Compilation of Historical Cliff Edges}

Coastal scientists in U.S. universities and government agencies have been quantifying rates of coastal cliff retreat and studying coastal change for decades. Before Global Positioning System (GPS) and lidar technologies were developed, the most commonly used sources of historical cliff edges were aerial photographs. Ideally, extraction of cliff edge position from these data sources involves orthorectification of the aerial photographs, followed by digitizing cliff edge position. Depending on coastal location, data source, and scientific preference, measurements can be made of the cliff top edge or cliff base, or both.

The USGS National Assessment of Shoreline Change analysis for California incorporates cliff top edge positions from two time periods and two unique data sources. The two time periods and data sources are 1920s-1930s NOS Topographic maps (T-sheets), and 1998 or 2002 lidar data, depending on availability. NOAA Coastal Services Center provided the USGS with digital T-sheets, which were then georeferenced in-house. The historical cliff edges from the 1920s-1930s, which were clearly delineated on most of the T-sheets, were digitized from the scanned and georeferenced historical T-sheets. Table 1 lists the range of years for cliff edges compiled for each period by region.

\section{Delineation of a Lidar-derived Cliff Edge}

The most recent cliff edge used in this National Assessment (1998/2002) was derived from lidar (Light Detection and Ranging) data. The USGS, in collaboration with NASA, has been using the NASA Airborne Topographic Mapper (ATM) to map coastal areas since 1997 (Krabill et al., 2000; Sallenger et al., 2003). The ATM surveys ground elevation using an elliptically rotating blue-green laser. GPS (global positioning system) positions and inertial navigation systems are used to correct for aircraft pitch, roll, and heading, providing ground elevations with accuracies of about $\pm 15 \mathrm{~cm}$ (Sallenger et al., 2003). The nominal point spacing for of the point cloud data was $3 \mathrm{~m}$. The lidar surveys used to derive cliff edges for this report were conducted either in 1998 or 2002 (table 1).

To compare with historical cliff edges, a methodology was developed to digitize cliff edges from the lidar surveys. The lidar point cloud data was gridded using a natural neighbors algorithm, at a 1-m cell size. A hillshade, which is a shaded surface based on the reflectance values and

Table 1. Ages of compiled cliff edges for the fifteen analysis regions

\begin{tabular}{|c|c|c|c|c|}
\hline \multirow[b]{2}{*}{.35} & & \multirow[b]{2}{*}{ Region } & \multicolumn{2}{|c|}{ Selected Periods } \\
\hline & & & $\begin{array}{l}\text { 1920s - 1930s } \\
\text { NOS T-sheets }\end{array}$ & $\begin{array}{c}\text { 1998/2002 } \\
\text { Lidar }\end{array}$ \\
\hline \multirow{4}{*}{ 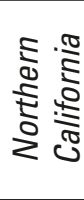 } & 1 & Klamath & $1926-1929$ & 2002 \\
\hline & 2 & Eureka & 1929 & 2002 \\
\hline & 3 & Navarro & 1929-1935 & 2002 \\
\hline & 4 & Russian River & 1929-1930 & 2002 \\
\hline \multirow{6}{*}{ 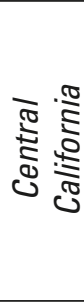 } & 5 & San Francisco N & 1929-1931 & 1998 \\
\hline & 6 & San Francisco $S$ & 1929-1932 & 1998 \\
\hline & 7 & Monterey Bay & 1932-1933 & 1998 \\
\hline & 8 & Big Sur & 1933-1934 & 1998-2002 \\
\hline & 9 & Morro Bay & 1934 & 1998-2002 \\
\hline & 10 & Santa Barbara. N & 1933-1934 & 1998 \\
\hline \multirow{5}{*}{ 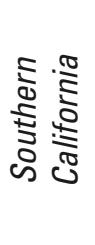 } & 11 & Santa Barbara S & 1932-1934 & 1998 \\
\hline & 12 & Santa Monica & 1933 & 1998 \\
\hline & 13 & San Pedro & 1920-1934 & 1998 \\
\hline & 14 & Oceanside & 1933-1934 & 1998 \\
\hline & 15 & San Diego & 1933 & 1998 \\
\hline
\end{tabular}


shading effects of surrounding surface features, was created from each grid. Hillshading is a useful tool for enhancing the visualization of a surface, and the resulting $3 \mathrm{D}$ rendering was used to hand-digitize the cliff edge using the visual break in slope (figure 1). This visual rendering approach has advantages over slope or second-derivative (gradient) methods of edge enhancement in that objects such as buildings or vegetation that are near the cliff edge are easier to identify and omit from the dataset. Using slope and gradient approaches were explored but found to be noisy, especially in areas where the top of the cliff is developed or vegetated close to the edge. For the slope method, data was gridded at a 1-m cell size and a slope map generated. More gently sloping areas were shaded darker and steeply sloping areas shaded lighter. The cliff edge was interpreted as the change in shade where there is an abrupt change in slope (figure 2A). Although this technique worked fairly well, it was difficult to interpret the cliff edge where the cliff slopes more gently, and where noise on the top of the cliff from vegetation or development obscured the cliff edge. The gra-
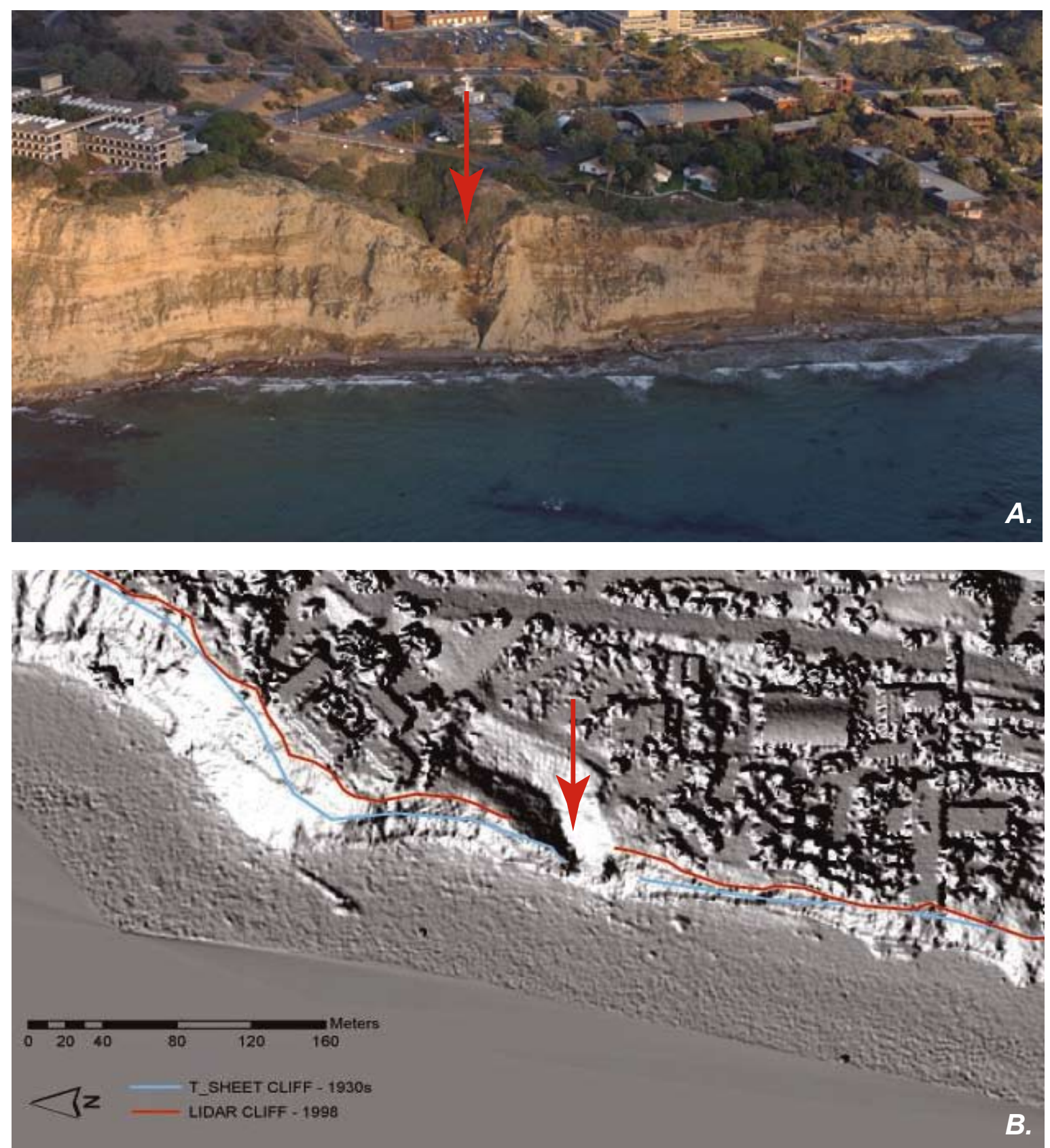

Figure 1. A) Oblique aerial photograph of cliffs at La Jolla. The red arrow points to the gully that can be clearly seen in the hillshade rendering, and B) Hillshade of lidar data of the same general area as (A). Features such as gullies, trees and buildings can easily be seen in the rendering. (photo: Copyright (C) 2002-2007 Kenneth \& Gabrielle Adelman, California Coastal Records Project, www.californiacoastline.org). 
dient rendering of the gridded lidar data, while well suited to dune environments (Elko et al., 2002), made it extremely difficult to interpret the edge of the cliff due to high slope gradients near the cliff edge from structures and vegetation (figure 2B). As a result, we found that the best and most consistent method of deriving a regional cliff edge from lidar data was to visually interpret the edge from hillshade renderings.

In addition to the challenges of developing a method to digitize the cliff edge in a consistent manner, the variable geomorphology of the rocky coastline in California makes the interpretation of what feature best represents the cliff edge difficult in some areas. In many places, the top of the cliff is a well-developed marine terrace with a distinct seaward edge (figure 3). However, in other areas there may be no well-defined break in slope, such as along the Big Sur coastline (figure 4), or there may be more than one break in slope (figure 5). In some cases these may be road or construction grades cut into an existing slope or are features associated with differential erosion of cliff-forming strata. In general, when these situations existed, the cliff edge interpreted from the lidar data was the same feature that was surveyed on the historical maps, as determined by superimposing the two data sets. Oblique aerial photographs and the historical maps were frequently utilized when digitizing the
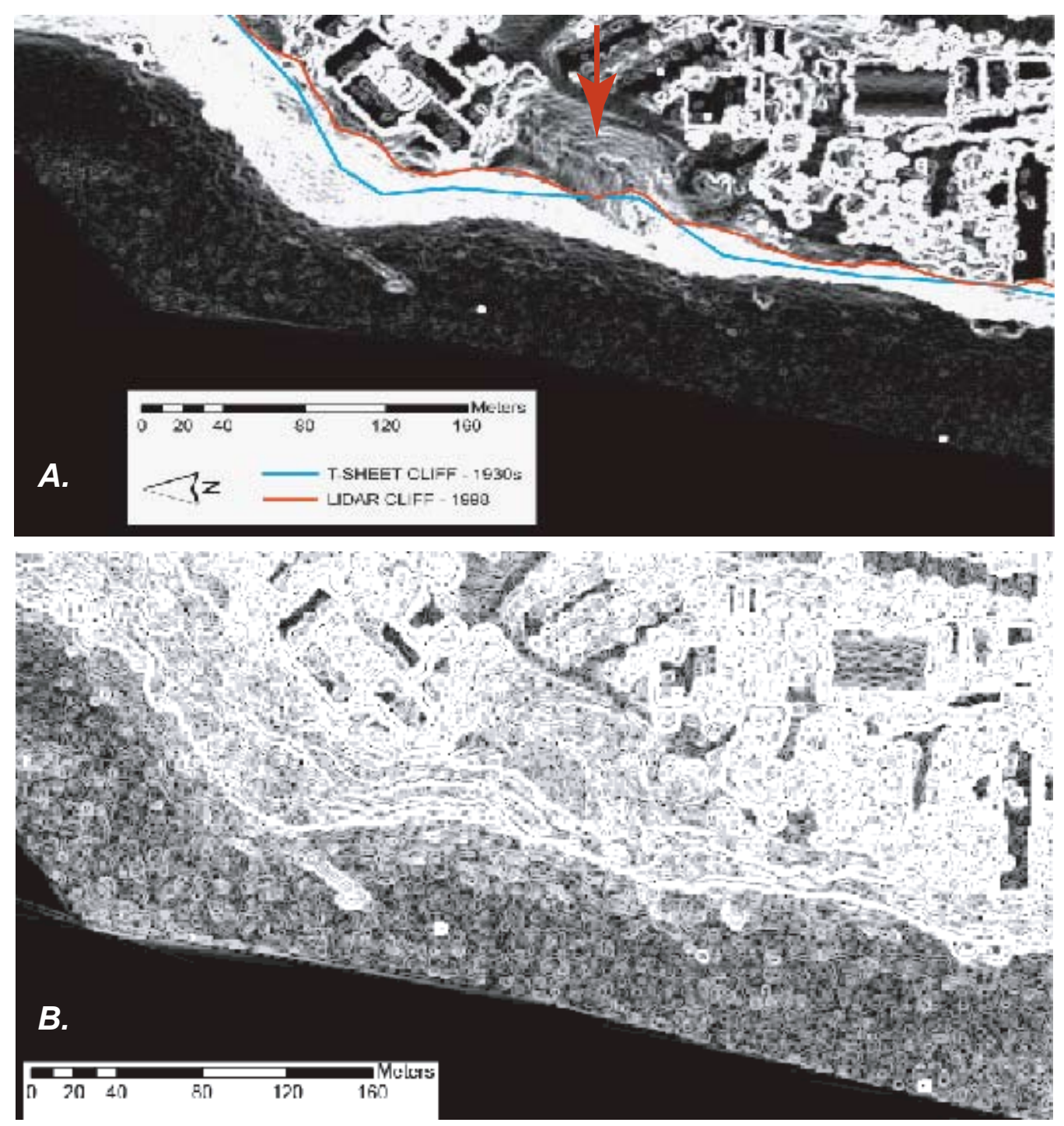

Figure 2. A. Slope image derived from lidar data of the same general area as shown in Figure 1. The red arrow indicates location of gully, which is somewhat ambiguous as a feature in the slope image. The cliff edges (red and blue lines) were digitized from the T-sheet and the slope image prior to the identification of the feature on oblique aerial photographs and the hillshade. In both cases, the gully was not identified correctly and the line was digitized across the mouth of the gully; and B.Gradient map of the gridded lidar data. The cliff edge is very difficult to identify due to buildings and vegetation near the cliff edge and the gully is not a readily identifiable feature. 


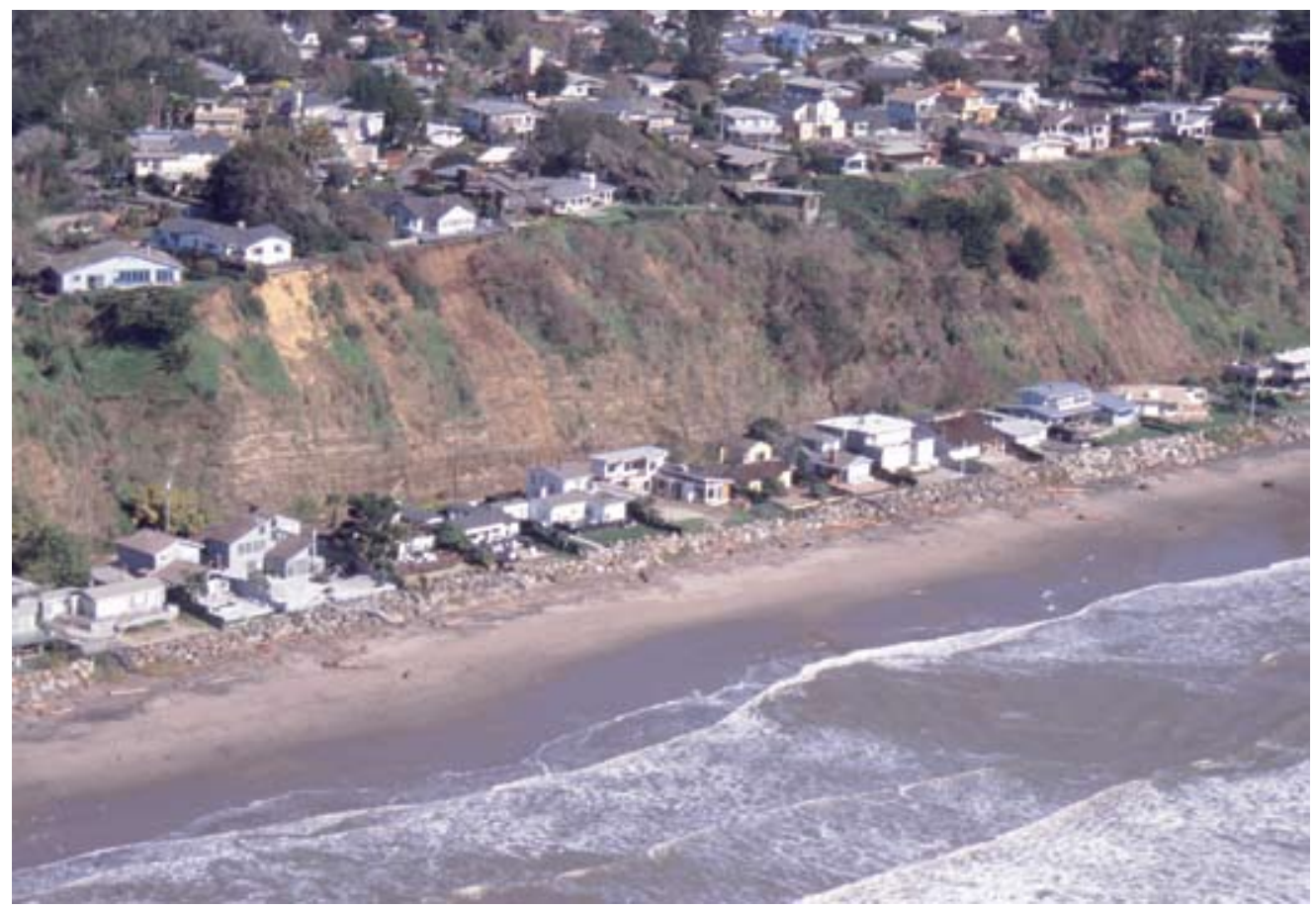

Figure 3. There is

development both on top of the marine terrace and at the base of the cliff in Northern Monterey Bay. The flat-topped marine terrace has a well-defined cliff edge, though it may be obscured by vegetation in some places (photo: Cheryl Hapke, USGS).

cliff edges from the hillshades to resolve ambiguities in the identification of the cliff edge.

There are many gaps in the cliff edge analysis, and as a result we present cliff retreat rates for $353 \mathrm{~km}$ of the California coast. This represents $28 \%$ of the rocky coastline of California, and $20 \%$ of the entire coast. Gaps are a function of lack of data (either lidar or historical maps), ambiguity in interpretation of cliff edge position, or lack of cliff along a given stretch of coastline. In addition, transects were eliminated in areas where there are long, narrow headlands or deep, narrow gullies, since these features represent singularities not representative of overall cliff change.

\section{Geographic Information System (GIS) Procedures}

The NOAA T-sheets used for the 1920s-30s cliff edge are the same as those used in the Historical Shoreline Change Analysis (Hapke et al., 2006) and details of the processing are described in that report. The total Root Mean

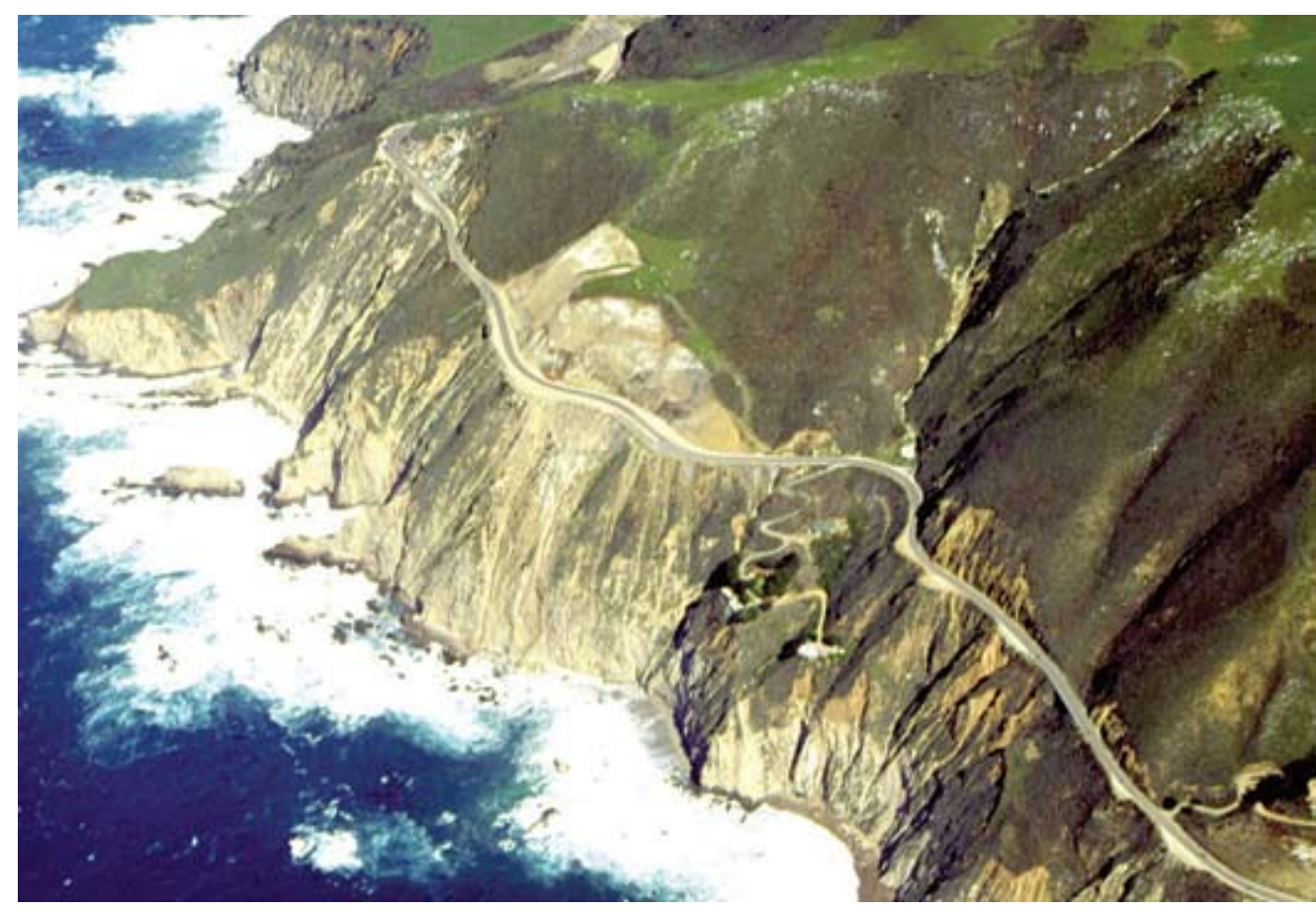

Figure 4. Big Sur coastline where a distinct cliff edge can be difficult to interpret or define. In general the first break or change in slope from the base is used, and in some areas this is the artificial road grade, such as can be seen in the photo. 


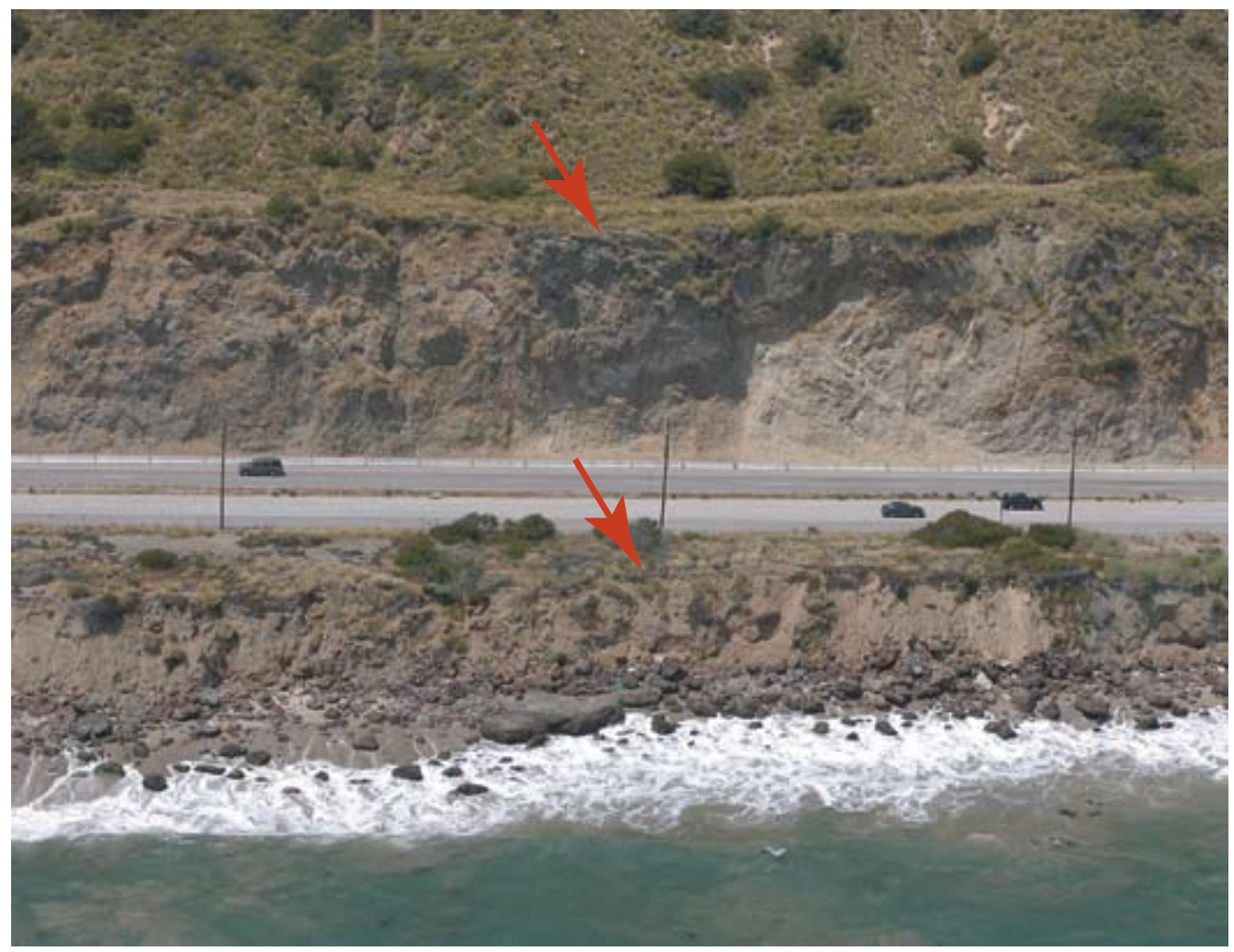

Figure 5. A stretch of coast

in Malibu where it is possible to interpret two cliff edges in the same location. The active seacliff (seaward-most edge) was digitized for this study. (photo: Copyright (c) 20022007 Kenneth \& Gabrielle Adelman, California Coastal Records Project, www. californiacoastline.org).

Square (RMS) error for the T-sheet georeferencing process was maintained below 1 pixel, which is approximately $4 \mathrm{~m}$ at a scale of 1:20,000 and approximately $1.5 \mathrm{~m}$ at a scale of 1:10,000. Typically the resulting RMS was much lower than one pixel. The data presented are in Universal Transverse Mercator (UTM) projection with the North American Datum of 1983 (NAD83).

\section{Calculation, Presentation and Interpretation of Rates of Change}

Rates of coastal cliff retreat were generated in a GIS with the Digital Shoreline Analysis System (DSAS), an ArcGIS@ tool developed by the USGS in cooperation with TPMC Environmental Services (Thieler et al., 2005). This tool contains three main components that define a baseline, generate transects perpendicular to the baseline that intersect the cliff edges at a user-defined separation along the coast, and calculate rates of change.

Baselines were constructed seaward of, and roughly parallel to, the general trend of the cliff edges. Using DSAS, transects were spaced at $20 \mathrm{~m}$ intervals. Transects were manually edited to assure they were as orthogonal to the cliff edges as possible. This is an issue along crenulated coastlines and can result in erroneously high retreat rates (figure 6). Rates of coastal cliff retreat were calculated at each transect using an end point rate, which is the change from one time period to the next, applied to both cliff edges.

In this report we describe cliff retreat rates, and amounts of retreat, as averaged over a $\sim 70$-year time period. While these data are frequently used in coastal zone management and can provide information on the spatial distribution of regional cliff retreat trends, they provide little information on specific hazard zones because of the highly episodic nature (both spatially and temporally) of coastal cliff retreat process and response. The dominant influences on the temporal variation of coastal cliff retreat are related to weather variations (storm intensity and frequency), climate variations (El Niño and Pacific Decadal Oscillation), and fluctuations in water level due to tides, storm waves, and eustatic sea-level rise. Spatial distributions in cliff retreat are related to the physical characteristics of the cliff-forming material (lithology and geologic structures), the orientation of the coastline with respect to the dominant wave direction, and anthropogenic impacts such as irrigation and the emplacement of protective structures.

On a short (seasonal) time scale, water levels along the California coast are higher due to storm waves. More water reaching the base of the bluff combined with increased pore pressure from the infiltration of rainfall will increase the likelihood of cliff failure. These types of failures tend to be highly localized, but occur across vast time scales and are thus extremely difficult to predict, both spatially and temporally. In addition, although seasonal storms drive the erosion of the coastal cliffs, cliff retreat is accelerated when storm frequency and intensity increase, such as during El Niño years. Several recent studies have directly correlated increased amounts of bluff retreat (Hapke and Richmond, 2002) and landslide failures (Hapke and Green, 2006) along the California coast to storms associated with El Niño winters. Several researchers have documented that storm inten- 

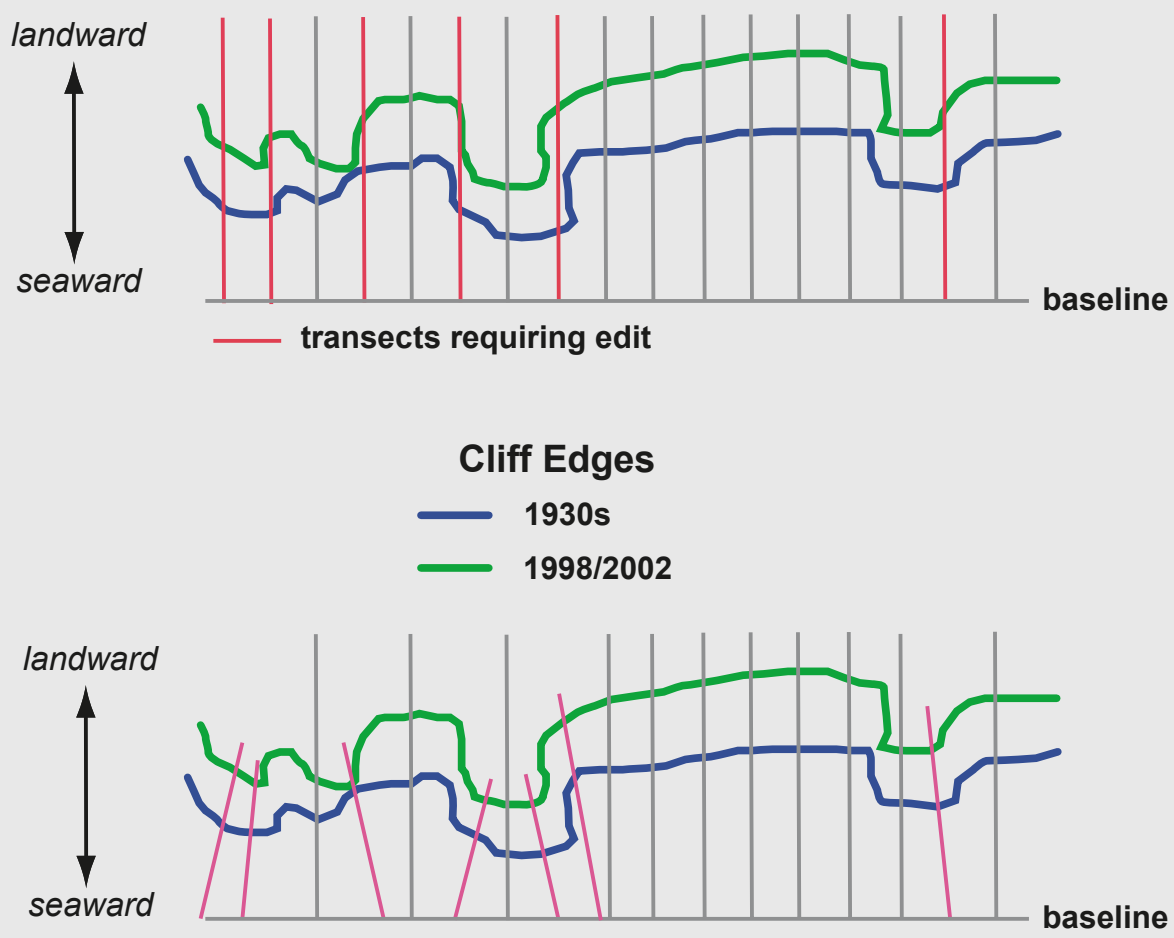

baseline

edited transects
Figure 6. Schematic diagram showing required transect edits that are common on crenulated coastlines. If the transects are left orthogonal to the baseline (top diagram), they may result in under- or over-estimation of the cliff retreat rate. The lower diagram shows the edited transects that more accurately reflects the retreat of the cliff edge. sity (Graham and Diaz, 2001) including storm wave heights and periods (Allen and Komar, 2000) in the North Pacific have been increasing over the past 50 years. Increased storminess coupled with sea-level rise, especially during El Niño years will likely lead to increases in both the length of time the base of the cliffs are exposed to waves, and the spatial extent of cliff-base wave exposure. This will ultimately result in an acceleration of cliff erosion. Earthquakes can also drive the retreat of coastal bluffs, as anecdotally documented during the 1906 San Francisco earthquake and as quantified by Plant and Griggs (1990a and 1990b) after the Loma Prieta earthquake.

A detailed analysis conducted by Hapke and Richmond (2002) assesses the short-term storm and earthquake-driven cliff retreat in the context of the longer-term (41-year) record. Their analysis clearly shows that the long-term rates are poor indicators of short-term erosion, and that short-term "hotspots" clearly shift spatially through time. It is important to note that because cliff retreat varies so considerably in space and time, the averaged data presented in this report is not a good predictor for future annual change.

\section{Coastal Cliff Alterations that Influence Rates of Change}

Attempts to stabilize coastal cliffs can greatly influence the rates of retreat. Activities such as the emplacement of seawalls and riprap tend to alter coastal and terrestrial processes and as a result, cliff edge position. For example, emplacement of a seawall is intended to stop the action of waves on the cliff base which drives cliff retreat. Although the bottom edge of the cliff may no longer undergo change, the top edge may continue to erode back for years after the seawall is in place, driven by terrestrial processes, until the slope reaches an equilibrium profile. At that time, cliff retreat should slow to a negligible rate unless the system becomes destabilized by severe events such as extreme storms or earthquakes, or if the seawall fails.

According to Griggs et al. (2005), $172 \mathrm{~km}$ of California's coast is armored with a seawall or revetment. Thus, the rates presented in this report are influenced by the existence of armoring, yielding an overall lower average retreat rate. Cliff retreat rates may also be indirectly influenced by manipulations to the amount of beach sediment in a given littoral system. For example, beach nourishment projects that widen a beach may provide protection from wave attack at the cliff base. Additionally, removal or reduction of sand from the littoral system in the form of damming of rivers or sand mining, may subsequently result in the narrowing of 
a protective beach, thus allowing waves to more regularly reach the base of the cliff. Differentiating between natural rates of erosion and the influences of erosion mitigation structures is difficult because experiments have not been conducted to specifically address this issue.

Human activities at the top of coastal cliffs can also influence cliff retreat rates. In California, an example of this is the extensive irrigation of crops or lawns on the top of the cliff, especially in the dry summer months. Coastal cliffs in California typically fail by either wave erosion, groundwater seepage from infiltration of precipitation (Emery and Kuhn, 1982), or a combination of both. Irrigation artificially increases the volume of infiltrating water, and may result in increases in pore pressures sufficient to drive slope failure. Also, seepage erosion or piping may occur. Additionally, the increase of impervious surfaces (e.g. driveways and parking lots) increases run-off and overland flow. If improperly channeled, this may result in increased formation of rills and gullies, which are common erosional features of softer cliff-forming materials.

\section{Uncertainties and Errors}

Documented trends and calculated rates of coastal cliff retreat are only as reliable as the measurement errors that determine the accuracy of each cliff edge position and statistical errors associated with compiling and comparing cliff edge positions. A variety of authors have provided general estimates of the typical measurement errors associated with mapping methods and materials for historical shorelines, registry of shoreline position relative to geographic coordinates, and shoreline digitizing (Anders and Byrnes, 1991; Crowell et al., 1991; Thieler and Danforth, 1994; and Moore, 2000). Fewer reports have been published that document errors associated with coastal cliff retreat, although it has been addressed by Moore and Griggs (2002) and Hapke (2004).

The largest errors in this analysis were positioning errors of $\pm 10 \mathrm{~m}$, which were attributed to scales and inaccuracies in the original T-sheet surveys. However, the influence of large position errors on long-term rates of change can be reduced if the rate is calculated over a sufficiently

Table 2. Estimated positional uncertainties for California cliff edges.

\begin{tabular}{lcc}
\hline \multicolumn{1}{c}{ Measurement Uncertainties (m) } & \multicolumn{2}{c}{ Time Period } \\
& 1920s-30s & 1998-2002 \\
\hline Georeferencing $\left(\mathrm{E}_{\mathrm{g}}\right)$ & 4.0 & -- \\
Digitizing $\left(\mathrm{E}_{\mathrm{d}}\right)$ & 1.0 & 1.0 \\
T-sheet survey/T-sheet, DRG position $\left(\mathrm{E}_{\mathrm{t}}\right)$ & 10 & -- \\
Lidar position uncertainty $(\mathrm{El})$ & -- & 1.0 \\
\hline Total position uncertainty $(\mathrm{Esp})(\mathrm{m})$ & 10.8 & 1.4 \\
Annualized retreat rate uncertainty $(\mathrm{m} / \mathrm{yr})$ & \multicolumn{2}{c}{0.2} \\
\hline
\end{tabular}

long period of time. Additional data source errors implicit in this analysis result from GPS positioning errors $( \pm 1 \mathrm{~m})$, which Stockdon et al. (2002) associated with the lidar data.

Estimates of the maximum measurement errors for this study are provided in table 2 to show how each error contributes to inaccuracy in the cliff edge position. The annualized error is calculated and subsequently incorporated into the cliff retreat rate calculations as outlined below. The uncertainty on the end-point rates, using a best estimate for California cliff edges is $\pm 0.2 \mathrm{~m} / \mathrm{yr}$ (table 2).

\section{End-point rate uncertainty}

The total cliff edge position error for the end-point retreat rate (Esp)(Equation 1), is calculated by taking the square root of the sum of the squares (or adding in quadrature) of: georeferencing error (Eg), digitizing error (Ed), $\mathrm{T}$-sheet survey error (Et), and lidar cliff edge position uncertainty $(\mathrm{El})$. The georeferencing error represents the elected maximum acceptable RMS error for T-sheets at a scale of 1:20,000 in this study. The digitizing error reflects the maximum error specified in past studies (Anders and Byrnes, 1991; Crowell et al., 1991; Moore, 2000), and is applied to the historical cliff edges only. The maximum Tsheet survey error, determined by Shalowitz (1964), incorporates all of the errors associated with the mapping process including distance to rodded points, plane table position, and identification of the cliff edge. Lidar cliff position error is the maximum error associated with the lidar positioning and GPS errors (Stockdon et al., 2002) for the modern date. Thus, total cliff edge position error as shown in table 2 for each cliff edge is expressed by:

$$
E_{s p}=\sqrt{E_{g}{ }^{2}+E_{d}{ }^{2}+E_{t}^{2}+E_{l}^{2}} \quad \text { (Equation 1) }
$$

A separate Esp is calculated for each time period ( and ). These values were combined and annualized to provide an error estimation for the cliff retreat rate at each transect. The annualized error (Ea) is expressed by:

$$
E_{a}=\frac{\sqrt{E_{s p 1}^{2}+E_{s p 2}^{2}}}{\text { time }} \quad \text { (Equation 2) }
$$


Comparisons of the results of this analysis to published analyses by Moore et al. (1999), Moore and Griggs (2002) and Young and Ashford (2006) suggest that the trends and relative rates of change presented in this study are in close agreement and are as accurate as the methodology allows.

\section{GEOMORPHOLOGY AND GEOLOGIC SETTING}

The detailed geologic history and geomorphology of the California coast are presented in the California Historical Shoreline Change report (Hapke et al., 2006). Additionally, several recent publications provide extensive scientific literature reviews and detailed background information on the processes of coastal cliff retreat in both California and the United States (Hampton and Griggs, 2004; Griggs et al., 2005). As such, only a broad outline of these topics will be discussed in this report.

The diverse geomorphology and complex geology of the California coast is largely a result of the interactions between the Pacific and North American tectonic plates. Movement along the San Andreas Fault Zone (SAFZ), the boundary between these plates along much of the California coast, resulted in the formation of the coastal mountain ranges, which are characterized by steep slopes, elevated marine terraces, and a wave-cut coastline. Marine terraces are geomorphic features that are perhaps of the most importance to coastal managers and planners in developed areas. These elevated features are generally flat-topped and provide excellent views of the ocean, and thus have been heavily developed throughout the state. Marine terraces are landforms that are created by marine processes and are above current sea level. Coastal cliffs are formed in the steep, erosional face of the elevated terraces. The terraces consist of a nearly flat platform that was formed by wave erosion during previous sea-level high stands, similar to modern intertidal platforms. The terraces are elevated above present sea levels by either the land rising, as is occurring along the tectonically active California coast, or by a fall in sea-level. In California, the majority of marine terraces are underlain by marine sandstones, siltstones and mudstones, which are topped by a relatively thin layer of poorly- to unlithified sands, gravels and cobbles. In many areas, multiple terraces are preserved, although many are degraded by processes of terrestrial erosion. The relict terraces represent a history of both tectonic uplift and fluctuations in sea-level going back hundreds of thousands of years.

Figure 7 is a generalized geologic map showing the major rock types of California (California Geological Survey, 2002). Tertiary and Mesozoic sedimentary rocks are the most common coastal rock type. The Mesozoic rocks are typically deeper marine sandstones and shales, whereas the Tertiary rocks tend to be sandstones and shales from more shallow marine environments. Crystalline rocks are also present along the coast and are most common in
Central California near San Francisco and Monterey. The rate at which the cliffs will erode is directly related to the strength of the coastal cliff-forming rocks (Benumoff et al., 2000; Hapke, 2005). Vertical and horizontal movement of rocks along the SAFZ has resulted in the juxtaposition of diverse rock types, and thus weak rocks are commonly juxtaposed against stronger rocks, creating large variations in cliff erosion rates over small spatial scales. Table 3 shows the approximate amount of different rock types for the cliffed portion of the California coast. Cliff retreat rates vary dramatically, from very low in granitic terranes to several meters per year in cliffs formed in poorly-consolidated sediment. The proximity to an active tectonic margin also results in highly fractured, sheared and jointed rocks along the California coast. Coastal cliffs are more prone to failure where bedding or structures are preferentially oriented, structure densities are greater, or where weak strata form a lower portion of the cliff.

Over 70\% of the coastline of California is backed by cliffs (Griggs and Patsch, 2004; figure 8), and these are generally categorized as either high-relief cliffs or as marine terraces. High cliffs occur where mountains directly border the coast such as along the Big Sur coast (figure 4) and much of northern California. The high cliffs may be hundreds of meters or more in height, they occupy about $13 \%$ of the California coastline (Griggs and Patsch, 2004), and are typically composed of more resistant rock types such as granite and the Franciscan Complex. Lower relief marine terraces and coastal bluffs (figure 3 ) form the remaining majority of cliffed coast and are more frequently associated with less resistant rock types, especially Tertiary sedimentary units.

\section{General Characteristics of the California Coast}

For this analysis the California coast is broadly divided into three sections: Northern, Central and Southern California. In addition, and for the purposes of assessment and interpretation of trends, the sections are further divided into fifteen analysis regions, as shown in figure 9. The coast of Northern California can be characterized as a rugged landscape with low population. The coast from the Oregon Border to Point Arena (figure 10A) is dominated by steep coastal cliffs that are dissected by numerous streams. Franciscan Complex rocks are common and the more resistant units often result in a coast with steep cliffs, small offshore islands and sea stacks. Marine terraces and wave-cut bluffs are common between the areas dominated by the steep cliffs.

Central California is the most diverse coastal region of the state, having characteristics of both the north and south regions. Marine terraces and coastal bluffs are well developed south of Point Reyes, in the Monterey Bay region, parts of the Big Sur coast, and stretches along the San Luis Obispo County coast (figure 10B). High relief coastal slopes occur at the Marin Headlands and Devils Slide north 


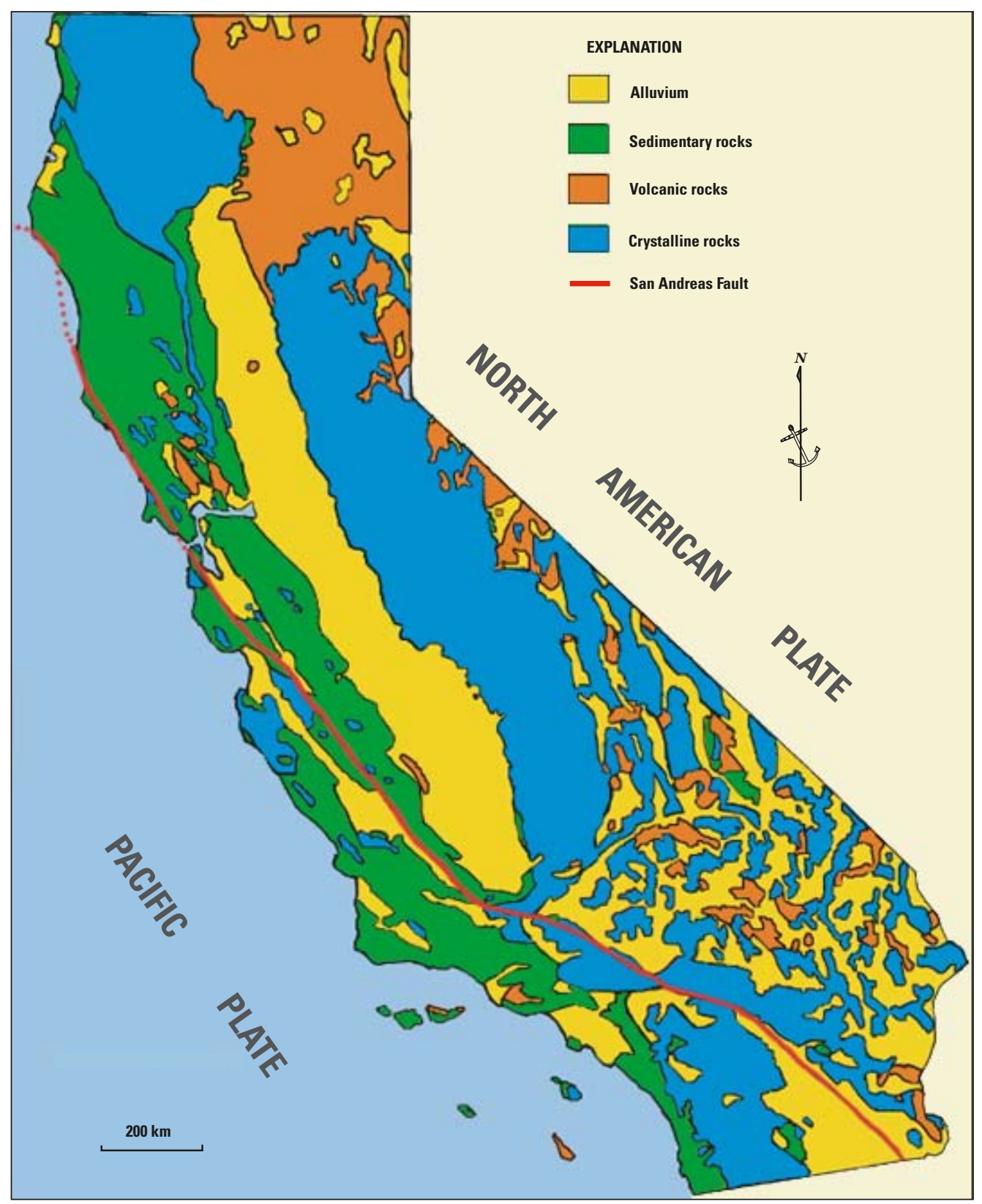

Figure 7. Simplified geologic map of California (from California Geological Survey, 2002).

and south of San Francisco respectively, and along most of the Big Sur coast. Between Morro Bay and Point Conception, coastal mountains alternate with intervening basins.

The coast of Southern California, extending from Point Conception to the Mexican border (figure 10C), is markedly different from the rest of the state. Point Conception marks a dramatic change in coastal orientation due to tectonic movement along the Transverse Ranges that has resulted in an east-west trending coast. Farther south, the coast gradually returns to the northwest-southeast trend. Coastal cliffs and marine terraces are widespread and are typically fronted by narrow beaches. This section is the most urbanized stretch of coast in California.

\section{HISTORICAL COASTAL CLIFF RETREAT ANALYSIS}

This section presents the results of the California coastal cliff retreat analysis. Each California section (Northern, Central and Southern) is subdivided into regions (figure 9 and figures 10A-C), which are based broadly on littoral cells and data coverage. The regions are the same as those used in the shoreline change analysis (Hapke et al., 2006). Table 4 summarizes the average cliff retreat rates and amounts within each region. Additionally, table 5 presents the maximum retreat for each region in California. 
Table 3. Coastal cliff rock and sediment types along the California coast (from Runyon and Griggs,

2002).

\begin{tabular}{ccc}
\hline Rock Type & Km of Coast & \% of Cliffed Coast \\
\hline Rock Type & & \\
Pliocene Marine & 688 & $39 \%$ \\
Miocene-Creataceous Marine & 335 & $19 \%$ \\
Older Metamorphic \& Sedimentary & 177 & $10 \%$ \\
(Franciscan) & & \\
Granitic & 53 & $3 \%$ \\
Volcanic & 18 & $1 \%$
\end{tabular}

Sediment Type

Unconsolidated Quaternary $\quad 480 \quad 28 \%$

Each description of cliff retreat within the regional assessments includes some information and discussion on human-induced changes. In many cases, the regional trends in cliff retreat can be related to human intervention within the natural coastal system. Engineering structures, such as seawalls and revetments, have altered cliff retreat rates by lowering or even halting wave impact at the cliff base. Additionally, human activities that disrupt the natural sediment supply may ultimately result in increases in the cliff retreat rates by reducing the size of protective beaches.

The average coastal cliff retreat rate for the State of California was $-0.3 \mathrm{~m} / \mathrm{yr}$. This is based on retreat rates averaged along a total of $353 \mathrm{~km}$ of the coast, or about $20 \%$ of the state. Data gaps were numerous, and often a function of the lack of a discernible cliff edge on the historical maps or from gaps in the lidar data which did not always extend inland far enough to capture the cliff edge.

Our analysis found that the highest average rates were in Northern California, and for an individual region, the Eureka region had the highest average retreat rate in the state $(-0.7 \mathrm{~m} / \mathrm{yr})$. Southern California had the lowest overall average cliff retreat rates, potentially because of the abundance of protective structures.

It is important to keep in mind that the change rates discussed in this report represent change measured through the date that the lidar was collected and thus may not reflect more recent trends in coastal cliff retreat. In addition, although retreat rates in some areas are relatively low, even a small amount of local erosion may present serious hazards to the coastal resources and community infrastructure in a given area.

\section{Northern California}

Northern California extends from the Oregon border to Tomales Point, a distance of approximately $500 \mathrm{~km}$ (figure 10A). For the presentation of the retreat rates, Northern California was divided into four regions: Klamath, Eureka, Navarro and Russian River. Northern California is domi- nated by a high-relief steep coastal slope geomorphology. The steep slope is interrupted where small streams and rivers drain to the coast. Marine terraces and wave-cut platforms occur sporadically along the coast.

Although the length of the Northern California coast (as defined in this report) is $499 \mathrm{~km}$, we measured retreat rates along $158 \mathrm{~km}$. The disparity is largely due to gaps in the data (both historical maps and lidar), as well as the few areas of coastline where cliffs are absent, such as near the mouths of large rivers (i.e. Klamath and Eel Rivers).

The average amount of coastal cliff erosion measured over 70 years in Northern California was $28.8 \mathrm{~m}$, and the average rate was $-0.5 \mathrm{~m} / \mathrm{yr}$, as measured on 2,325 transects. Many of the highest rates in Northern California were measured along headlands that lie in between embayments. The embayments occur either where there are small creeks draining the coastal slope, or in many cases they are deep-seated landslide complexes with wavelengths (distance from the center of one embayment to the next) on the order of $1 \mathrm{~km}$.

\section{Klamath Region}

The Klamath region covers approximately $100 \mathrm{~km}$ of coastline and extends from the Oregon border to Patrick's Point (figure 10A). The coast is sparsely populated, except for the area around Crescent City. Cliff retreat rates were calculated along $6 \mathrm{~km}$ of coastline. The average amount of retreat was $36.2 \mathrm{~m}$ and the average retreat rate was $-0.5 \mathrm{~m} / \mathrm{yr}$ (table 4), one of the highest in the state.

The highest rates occurred along a remote and steep section of coast, approximately $3 \mathrm{~km}$ north of the Klamath River mouth (figure 11; table 5), where nearly $168 \mathrm{~m}$ of cliff retreat occurred over the $\sim 70$-year time period of this study. Figure 12A shows the small headland that exhibited the highest retreat amount and retreat rate $(-2.3 \mathrm{~m} / \mathrm{yr})$. In general, the higher rates in the region appeared to be focused on small headlands such as this. Based on the focused nature (occurring at a specific location) of the measured maximum retreat it is likely associated with the collapse of a sea cave 


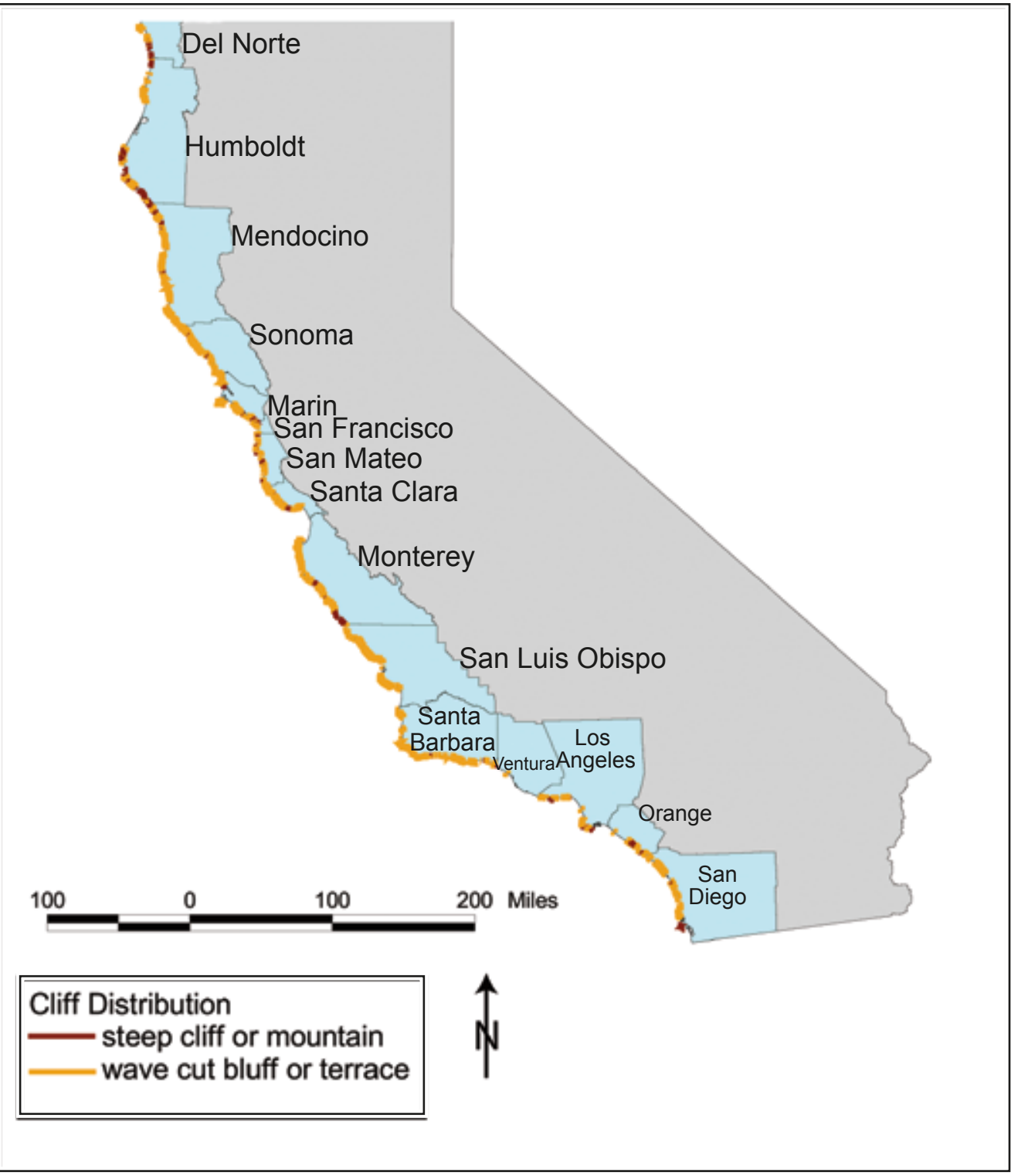

Figure 8. Map of the distribution of cliffs along the California coast, and characterization as either step cliff or wave cut terrace. Blue outlines are the coastal counties (From Griggs and Patsch, 2004).

at the northern end of the headland,. Retreat rates were also high $(-1.4 \mathrm{~m} / \mathrm{yr}$ ) at Big Lagoon (figure 11). In this area, rapidly eroding, poorly lithified Quaternary strata overlie Franciscan Complex rocks (Aalto, 1989; figure 12B). The rates at Big Lagoon agree well with those cited in Savoy et al. (2005a).

\section{Eureka Region}

The Eureka region begins $6 \mathrm{~km}$ south of Trinidad Head and extends $154 \mathrm{~km}$ south to Cape Mendocino (figures 9 and 10A). The Eureka region is the most developed and populous coastal area of the four Northern California regions. Development is focused in the coastal lowlands between the Mad River and the Eel River, and includes the towns of Eureka and Arcata. To the north and south of the coastal lowlands, the geomorphology is dominated by steep, high-relief coastal slopes. The average retreat rate for the region was $-0.7 \mathrm{~m} / \mathrm{yr}$, the highest of all the average rates in the Northern California regions studied. The average amount of retreat, also the highest in California, was $53.4 \mathrm{~m}$.

The highest amounts of retreat and the highest rates were measured at False Cape, just north of Cape Mendocino (figure 13 and table 5). In this location, there is a large deep-seated landslide complex, and the disrupted landslide material is eroding rapidly via rill and gully formation (figure 14A). In this area, the cliff retreated more than $150 \mathrm{~m}$ over a 70 -year period. Other similarly high rates 


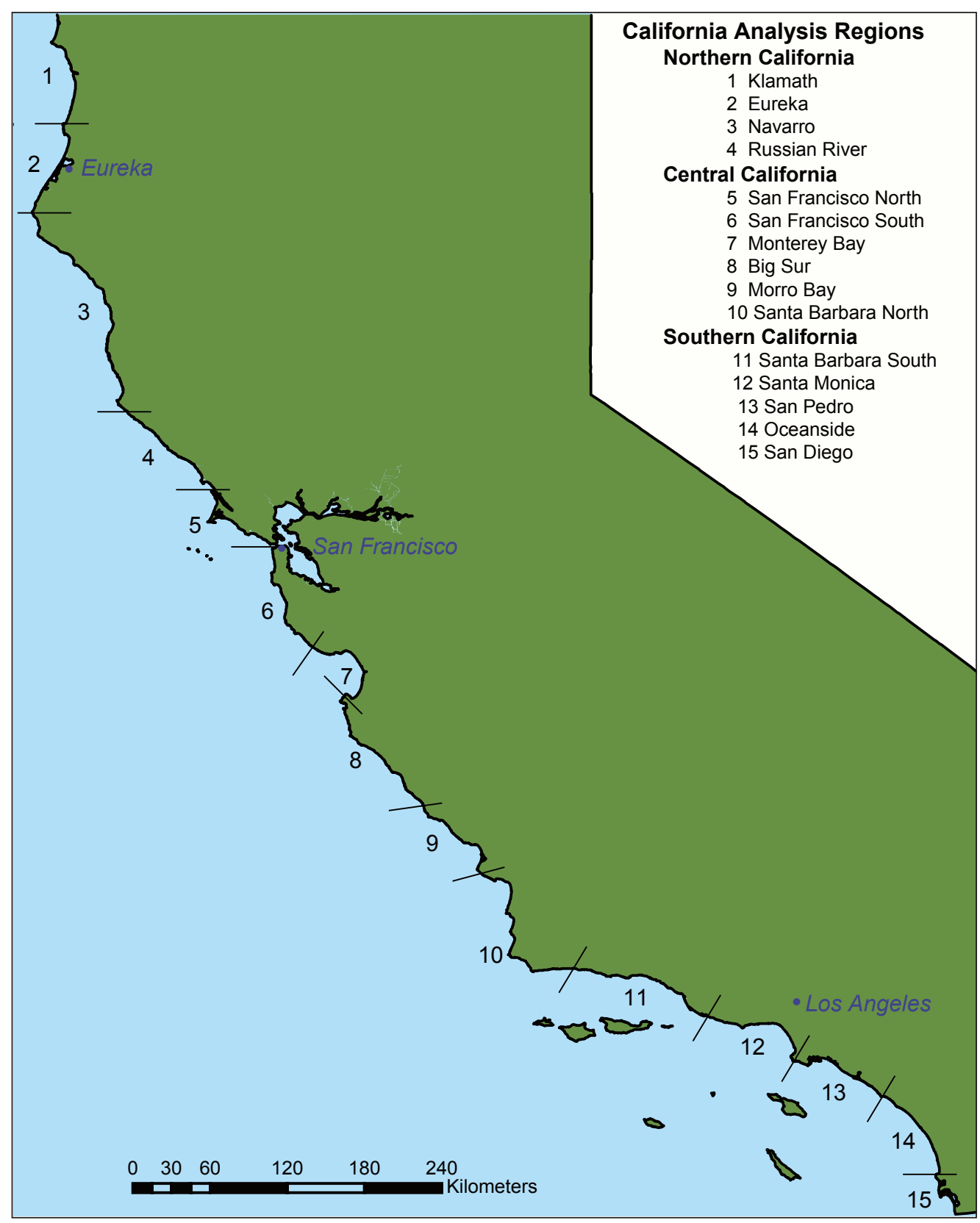

Figure 9. Index map of California showing the relative locations of the fifteen analysis regions discussed in the text.

(-2.0 m/yr) occurred at Elk Head where unlithified terrace deposits overlie bedrock on a section of marine terrace. The edge of cliff is formed in the softer material and is eroding rapidly (figure 14B).

\section{Navarro Region}

The Navarro region extends from Point Delgada in the north to Point Arena in the south, a $142 \mathrm{~km}$ section of coastline (figure 9). This region is very rugged, inaccessible, and has is little development. With a few exceptions, the coast in the Navarro region is crenulated and rocky with steep cliffs. Additionally, there are some scattered pocket beaches and occasional narrow beaches fronting the cliff.
Cliff retreat was measured along $29 \mathrm{~km}$ of the Navarro region coastline. The rates in the region are some of the highest in the state, although the regional average $(-0.4$ $\mathrm{m} / \mathrm{yr}$ ) is lower than that of the Eureka region. The northern portion of the Navarro region has consistently high retreat rates (figure 15), including the highest rate measured in the state $(-3.1 \mathrm{~m} / \mathrm{yr})$. This location, at the southern end of Rockport Bay, is an area of active, deep-seated landslides along the steep coastal slope (figure 16A) and is where the maximum retreat in the state, $222.7 \mathrm{~m}$ was measured. Relatively high rates in the southern portion of the region, south of Fort Bragg, were measured on a headland between Mallo Pass Beach and Irish beach (figure 10A). In this area, a residential development may ultimately be threatened if the measured retreat rates of $>1.0 \mathrm{~m} / \mathrm{yr}$ continue (figure $16 \mathrm{~B}$ ). 


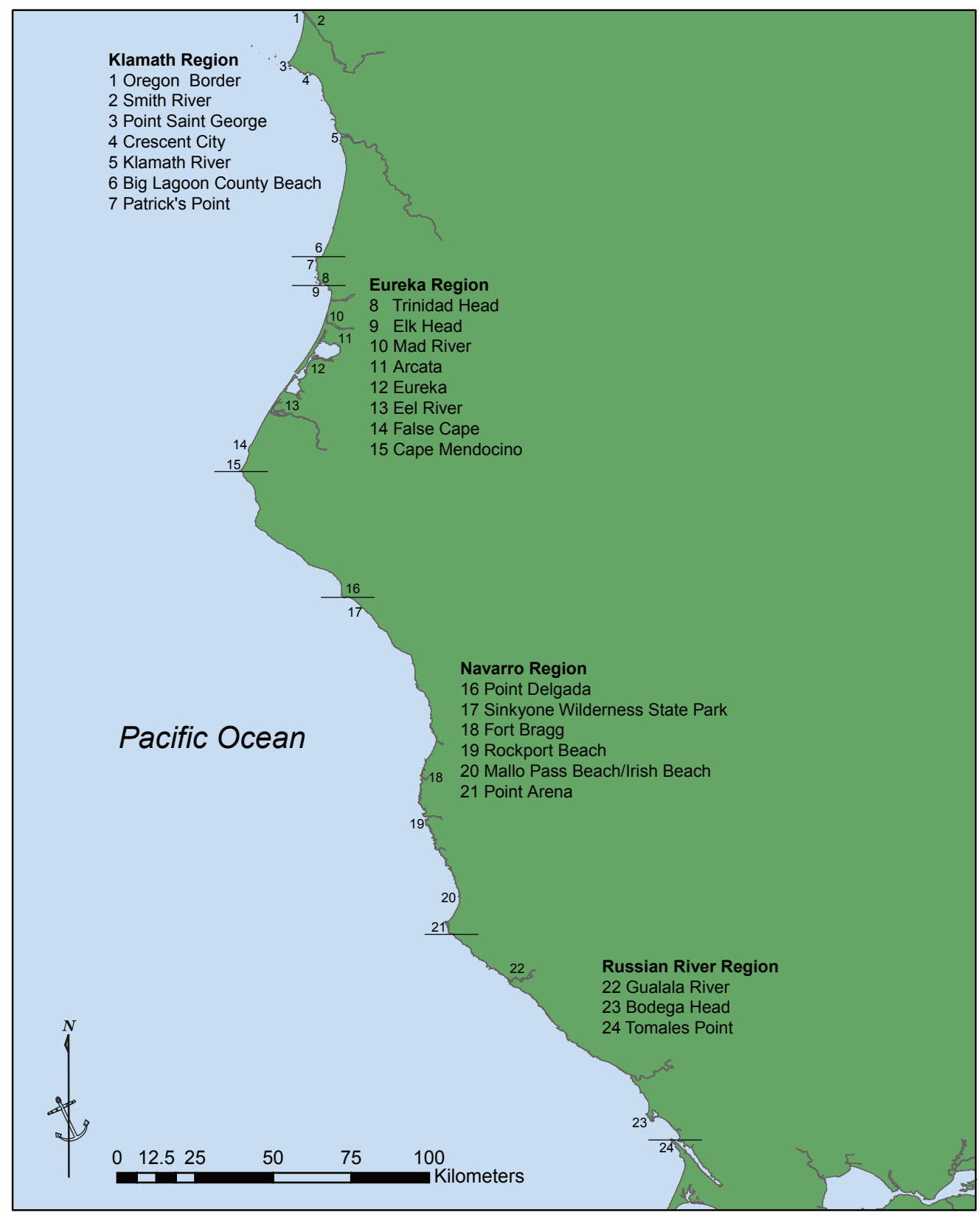

Figure 10A. Index map of Northern California showing the four analysis regions and specific locations of geographic places discussed in the text.

\section{Russian River Region}

The Russian River region begins $12 \mathrm{~km}$ south of Point Arena and extends for $102 \mathrm{~km}$ along a remote and rocky stretch of coastline to Tomales Point in the south (figure $10 \mathrm{~A})$.

The cliff retreat data for this region are discontinuous and widely distributed, especially in the northern portion of the region (figure 17). The average retreat rate is $-0.2 \mathrm{~m} / \mathrm{yr}$, the lowest in Northern California, and the average amount of retreat was only $15.3 \mathrm{~m}$, which is also low compared to the rest of Northern California.
The highest retreat is $60.5 \mathrm{~m}$, an order of magnitude lower than the maximum retreat amounts in the rest of Northern California. This maximum retreat translates to a rate of $-0.8 \mathrm{~m} / \mathrm{yr}$, and was measured along Bodega Head. The granitic bedrock at Bodega Head is highly fractured and sheared due to its proximity to the SAFZ. Bodega Head is on the west side of the SAFZ, and moved nearly $3 \mathrm{~m}$ to the north during the 1906 earthquake (Savoy et al., 2005b). The cliff retreat here is the result of slope failures within the unlithified sands (figure 18) that overlie the granitic bedrock. 


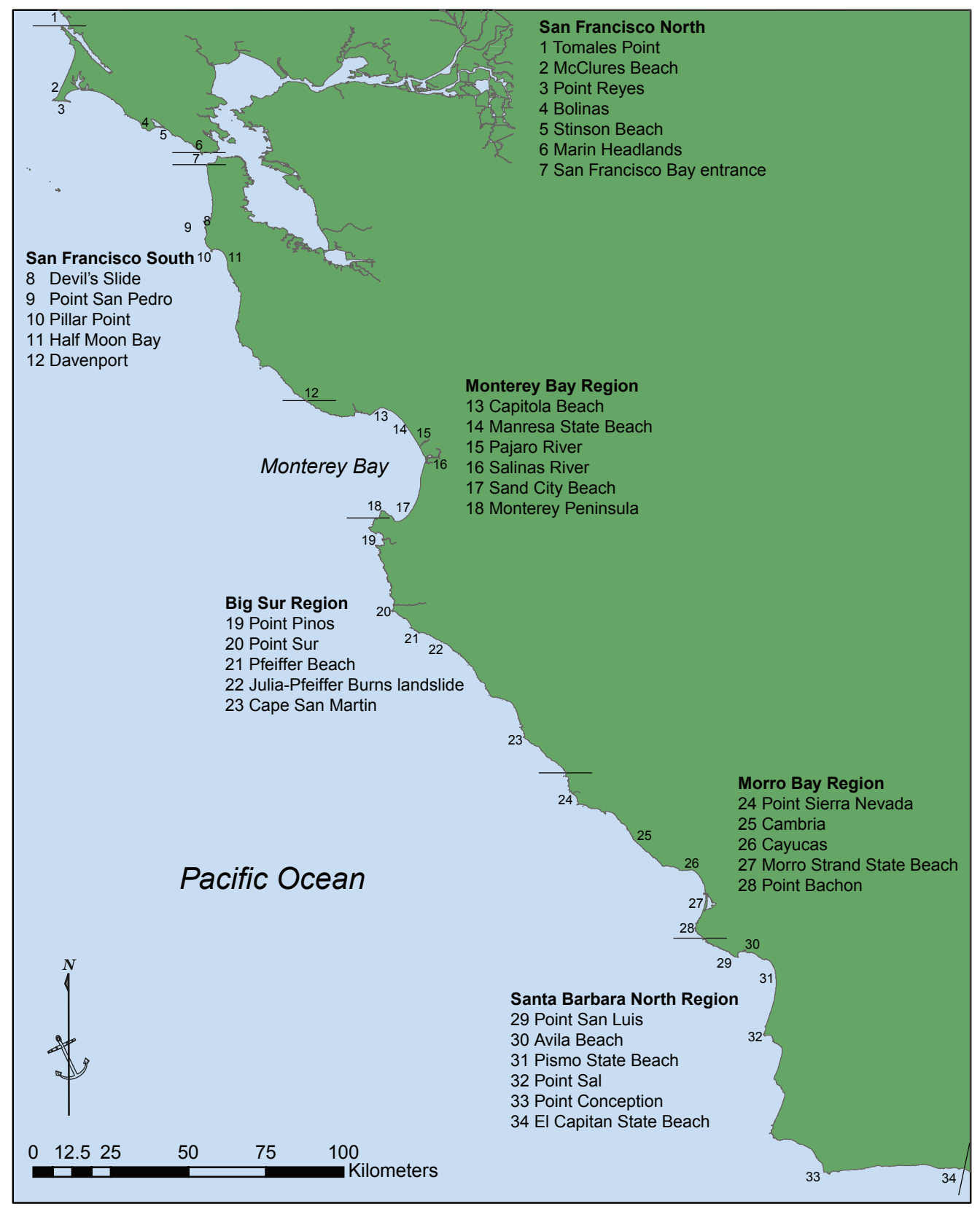

Figure 10B. Index map of Central California showing the six analysis regions and specific locations of geographic places discussed in the text.

\section{Central California}

The Central California section begins just south of Tomales Point and extends south to El Capitan State Beach, east of Point Conception, a total distance of approximately $700 \mathrm{~km}$ (figures 9 and 10B). Central California is divided into six analysis regions including San Francisco North, San Francisco South, Monterey Bay, Big Sur, Morro Bay and Santa Barbara North (figure 9).

The Central California coast has a more mixed geomorphology than Northern California, in that there are areas of high-relief coast (the Big Sur coast, and north of the Marin Headlands; figure 10B), long stretches of well- developed, elevated marine terraces, and coastal lowlands that are typically associated with river mouths. Cliff retreat for Central California was measured along $208 \mathrm{~km}$ of coastline, the average retreat rate was $-0.3 \mathrm{~m} / \mathrm{yr}$, and the average amount of retreat was $17.3 \mathrm{~m}$ over a 70 -year period. Numerous seawalls and revetments exist along this stretch of coast, especially in more heavily developed areas. These structures, built in response to cliff erosion threatening private homes and/or community infrastructure act to reduce the rate of cliff retreat. 


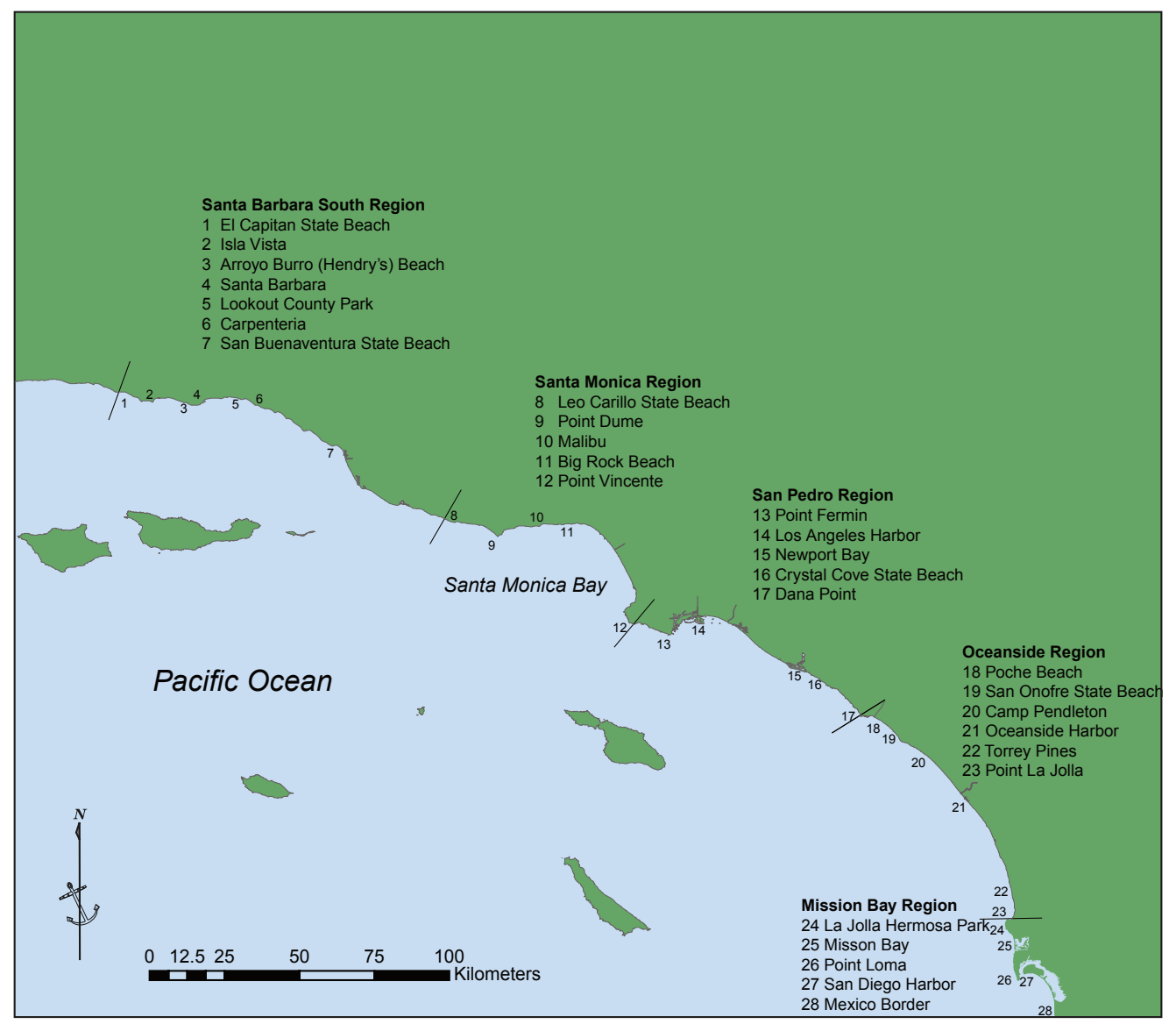

Figure 10C. Index map of Southern California showing the five analysis regions and specific locations of geographic places discussed in the text.

\section{San Francisco North Region}

The San Francisco North region begins at Tomales Bay and extends $119 \mathrm{~km}$ to the northern side of the entrance to San Francisco Bay (figure 10B). This is a relatively undeveloped rocky coastline, with high-relief coastal slopes or narrow beaches backed by high coastal cliffs. The exception is the developed communities around Bolinas and Stinson Beach. The average retreat rate for the region was -0.5 $\mathrm{m} / \mathrm{yr}$, the highest regionally averaged rate in Central California. The average amount of retreat was $36.2 \mathrm{~m}$, and was measured along $22 \mathrm{~km}$ of coastline.

Similar to the Russian River Region, the highest rates were measured along steep cliffs on a headland. Point Reyes (figure 19) lies on the western (Pacific Plate) side of, and in close proximity to, the SAFZ. The maximum rate in this region, $-1.9 \mathrm{~m} / \mathrm{yr}$, was measured along the south-facing cliffs of Point Reyes headland (figure 20), which is composed of granitic and metamorphic rocks overlain by poorly lithified marine sedimentary units (Savoy et al., 2005b). Slope failures within the overlying materials result in the high erosion rates. Other areas where high rates were measured in the San Francisco North region (figure 19) include the steep cliffs backing McClures Beach north of Point
Reyes, and along the promontory connecting Bolinas and Duxbury Points (figure 10B).

\section{San Francisco South Region}

The San Francisco South region is $99 \mathrm{~km}$ long and extends from the mouth of San Francisco Bay to Davenport (figures 9 and 10B). The geomorphology of the coastline is variable, with linear beaches backed by dunes, steep cliffs with narrow fronting beaches, rocky coast with small pocket beaches, and steep, high-relief coast with no sandy shoreline. The average cliff retreat rate in this region was relatively low, $-0.2 \mathrm{~m} / \mathrm{yr}$, and the average amount of retreat was $16.4 \mathrm{~m}$, as measured along $31 \mathrm{~km}$. However, on the north side of Pillar Point, near the famous Maverick's surfbreak, the highest rate in this region, $-3.1 \mathrm{~m} / \mathrm{yr}$, was measured. This translates to over $210 \mathrm{~m}$ of retreat, and is equivalent to the highest retreat and retreat rate in the state, which was measured in the Navarro region (table 5). The cliffs in this area are high (as high as $40 \mathrm{~m}$ ) and are composed of a resistant basal mudstone unit overlain by sand and gravel deposits (figure 21) (Griggs et al., 2005b).

High cliff retreat rates occur consistently along the promontory between Half Moon Bay (to the south) and 
Table 4. Number of transects, coastal extents and average cliff retreat rates for California

\begin{tabular}{lccccc}
\hline \multicolumn{1}{c}{ REGION } & $\begin{array}{c}\text { Number of } \\
\text { Transects }\end{array}$ & $\begin{array}{c}\text { Length of } \\
\text { Region }(\mathbf{k m})\end{array}$ & $\begin{array}{c}\text { Length of } \\
\text { Measured Cliffs } \\
(\mathbf{k m})\end{array}$ & $\begin{array}{c}\text { Average Retreat } \\
\text { Rate } \\
(\mathbf{m} / \mathbf{l r}) \pm \mathbf{0 . 2}\end{array}$ & $\begin{array}{c}\text { Average Retreat } \\
\text { amount } \\
(\mathbf{m}) \pm \mathbf{1 0 . 9}\end{array}$ \\
\hline Klamath & 319 & 101 & 6 & -0.5 & -36.2 \\
Eureka & 135 & 154 & 3 & -0.7 & -53.4 \\
Navarro & 1441 & 142 & 29 & -0.4 & -28.9 \\
Russian River & 433 & 102 & 9 & -0.2 & -15.3 \\
Northern CA & $\mathbf{2 3 2 5}$ & $\mathbf{4 9 9}$ & $\mathbf{4 7}$ & $-\mathbf{0 . 5}$ & $-\mathbf{2 8 . 8}$ \\
& & & & & \\
San Francisco N & 1092 & 119 & 22 & -0.5 & -36.2 \\
San Francisco S & 1551 & 99 & 31 & -0.2 & -16.4 \\
Monterey Bay & 1098 & 76 & 22 & -0.4 & -24.4 \\
Big Sur & 1929 & 145 & 39 & -0.3 & -17.2 \\
Morro Bay & 738 & 91 & 15 & -0.2 & -12.6 \\
Santa Barbara N & 3982 & 174 & 80 & -0.2 & -11.3 \\
Central CA & $\mathbf{1 0 3 9 0}$ & $\mathbf{7 0 4}$ & $\mathbf{2 0 8}$ & $-\mathbf{0 . 3}$ & -17.3 \\
& & & & & -13.3 \\
Santa Barbara S & 828 & 111 & 17 & -0.2 & -17.9 \\
Santa Monica & 1118 & 91 & 22 & -0.3 & -9.8 \\
San Pedro & 498 & 87 & 10 & -0.2 & -12.0 \\
Oceanside & 1993 & 86 & 40 & -0.2 & -12.0 \\
San Diego & 501 & 48 & 10 & -0.2 & $-\mathbf{1 3 . 3}$ \\
Southern CA & $\mathbf{4 9 3 8}$ & $\mathbf{4 0 0}$ & $\mathbf{9 9}$ & $-\mathbf{0 . 2}$ & $-\mathbf{1 7 . 7}$ \\
\hline & & & & $-\mathbf{0 . 3}$ & \\
State totals & $\mathbf{1 7 6 5 3}$ & $\mathbf{1 6 0 3}$ & $\mathbf{3 5 3}$ & & \\
\hline
\end{tabular}

Point San Pedro to the north (figures 10B and 22). This area includes Devil's Slide, a large landslide complex on which chronic, frequent movement prompted the relocation of Coast Highway 1.

In general, the higher rates north of Half Moon Bay are attributed to movement on deep-seated landslides along high-relief coastal slopes, on or near promontories and headlands. In contrast, to the south of Half Moon Bay, elevated marine terraces are the dominant geomorphic feature and the process of retreat are slumps and blockfalls rather than large deep-seated slides.

\section{Monterey Bay Region}

The Monterey Bay region begins just north of Davenport in Santa Cruz County and extends $76 \mathrm{~km}$ south to the northeastern tip of the Monterey Peninsula (figure 10B). This region is characterized by a geomorphically variable coast that includes rocky headlands, pocket beaches, well-developed marine terraces and linear beach and dune systems. The average cliff retreat rate for the Monterey Bay region was $-0.4 \mathrm{~m} / \mathrm{yr}$, which translates to $24.4 \mathrm{~m}$ of retreat, and was measured along $22 \mathrm{~km}$ of coastline. The data in this region are relatively continuous (figure 23), primarily because most of the cliffs, especially in the northern half of Monterey Bay, are marine terraces with well-defined edges. There is a large break in data coverage where coastal lowlands surrounding the Pajaro and Salinas River mouths drain into Monterey Bay.

The highest rates were measured in Southern Monterey Bay, where bluffs are formed in unlithified Quaternary sand dunes. The erosion rate increases to the south (figure 23) and was highest $(-1.8 \mathrm{~m} / \mathrm{yr})$ where there has been a long history of sand-mining of the dunes (Thornton et al., 2006). In this area of chronic erosion, Stillwell Hall, a soldier's club on the Fort Ord military base, was removed in 2004 after years of being threatened by bluff failure (figure 24). The amount of retreat measured over the 70-year time period was $\sim 116 \mathrm{~m}$.

As compared to previous studies, the retreat rates in Northern Monterey Bay were in good agreement with Moore et al. (1999), especially in the areas near Capitola and Manresa State Beach, and the rates reported in Southern Monterey Bay were in good agreement with Thornton et al. (2006). 
Table 5. Maximum cliff retreat rates and locations of maximums for the fifteen analysis regions.

\begin{tabular}{|c|c|c|c|c|}
\hline & REGION & $\begin{array}{c}\text { Max. Retreat } \\
\text { Rate } \\
(\mathrm{m} / \mathrm{yr}) \pm 0.2\end{array}$ & $\begin{array}{c}\text { Max. Retreat } \\
\text { Amount } \\
(\mathrm{m}) \pm 10.9\end{array}$ & Location \\
\hline \multirow{4}{*}{ 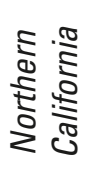 } & Klamath & -2.3 & -167.9 & $2.6 \mathrm{~km}$ north of the Klamath River mouth \\
\hline & Eureka & -2.2 & -161.3 & False Cape, 7.3 km north of Cape Mendocino \\
\hline & Navarro & -3.1 & -222.7 & Rockport Beach, near Cape Vizcaino \\
\hline & Russian River & -0.8 & -60.5 & Bodega Head \\
\hline \multirow{6}{*}{ 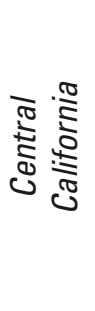 } & San Francisco N & -1.9 & -138.7 & Point Reyes \\
\hline & San Francisco S & -3.1 & -210.5 & $2.3 \mathrm{~km}$ north of the Pillar Point Harbor breakwater \\
\hline & Monterey Bay & -1.8 & -116.4 & Sand City Beach \\
\hline & Big Sur & -2.2 & -147.6 & Pfeiffer Beach \\
\hline & Morro Bay & -0.8 & -52.5 & $3 \mathrm{~km}$ north of Cayucos beach \\
\hline & Santa Barbara N & -1.3 & -81.3 & Point Sal \\
\hline \multirow{5}{*}{ 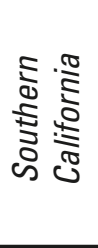 } & Santa Barbara S & -1.0 & -63.1 & Arroyo Burro (Hendry's) Beach \\
\hline & Santa Monica & -1.8 & -115.1 & Big Rock Beach, Bick Rock Mesa landslide \\
\hline & San Pedro & -1.0 & -64.0 & Point Fermin, Sunken City landslide \\
\hline & Oceanside & -1.7 & -110.1 & San Onofre Beach South \\
\hline & San Diego & -1.6 & -99.8 & Sunset Cliffs, Point Loma \\
\hline
\end{tabular}

\section{Big Sur Region}

The Big Sur region extends along $145 \mathrm{~km}$ of largely remote and rugged coastline from Point Piños in the north to just south of Cape San Martin (figure 10B). The geomorphology of the Big Sur coast more resembles that of regions in Northern California than the other analysis regions in Central California. The principal mechanisms of retreat along this coast are large, deep-seated landslides and remobilization of incoherent landslide deposits. Rates were consistently high throughout the Big Sur region (figure 25), the average rate for the region area was $-0.3 \mathrm{~m} / \mathrm{yr}$, and the average amount of retreat was $17.2 \mathrm{~m}$.

The highest rates in the region, $-2.2 \mathrm{~m} / \mathrm{yr}$, were measured just south of Pfeiffer Beach along a steep, rugged stretch of coast (figure 26A), where the coastal slope has retreated nearly $150 \mathrm{~m}$ in the 70-year period of this analysis. The high-relief coastal slope at this location is formed in weak Franciscan Complex rocks. This area is not especially known as a high hazard area, most likely because the Pfeiffer Beach location is along a remote stretch of coast away from development or the nearby Coast Highway 1. Another location with a high retreat rate is the Julia Pfeiffer Burns (JP Burns) landslide complex (figures 10B and 26B) which has the second highest rates in the region. The JP Burns slide occurred in the winter of 1983, and closed Coast Highway 1 for nearly a year. The rates reported for the Big Sur region and for these two specific locations are similar to those presented by Hapke and Green (2004).

\section{Morro Bay Region}

The Morro Bay region is $91 \mathrm{~km}$ long and includes the section of coast from just north of Point Sierra Nevada to Point Bachon in the south (figures 9 and 10B). This is a lower relief coast than the Big Sur region to the north, with much of the coastline characterized by low marine terraces formed in Franciscan Complex metasedimentary rocks (Hapke, 2005). The average retreat rate was -0.2 $\mathrm{m} / \mathrm{yr}$, which translates to $12.6 \mathrm{~m}$ (table 4 ), and retreat occurs primarily as a result of erosion of the poorly lithified marine terrace deposits that overlie the Franciscan Complex bedrock.

The highest amount of cliff retreat in the Morro Bay region was $52.5 \mathrm{~m}$ and the rate of retreat was $-0.8 \mathrm{~m} / \mathrm{yr}$. The location of the maximum retreat was measured along an undeveloped stretch of coast $4 \mathrm{~km}$ north of Cayucos Beach (figure 27 and table 5). Rates are also relatively high (-0.6 $\mathrm{m} / \mathrm{yr}$ ) in the bluffs immediately adjacent to Cayucos Beach, where some private homes are threatened by the retreat of the bluff (figure 28). High rates in this region were also measured at Morro Strand State Beach (figure 27) where the bluffs are cut into soft Quaternary sand dunes.

\section{Santa Barbara North}

The Santa Barbara North region extends for $174 \mathrm{~km}$ from Point San Luis in the north to El Capitan State Beach in the south (figures 9 and 10B). Most of region is remote 


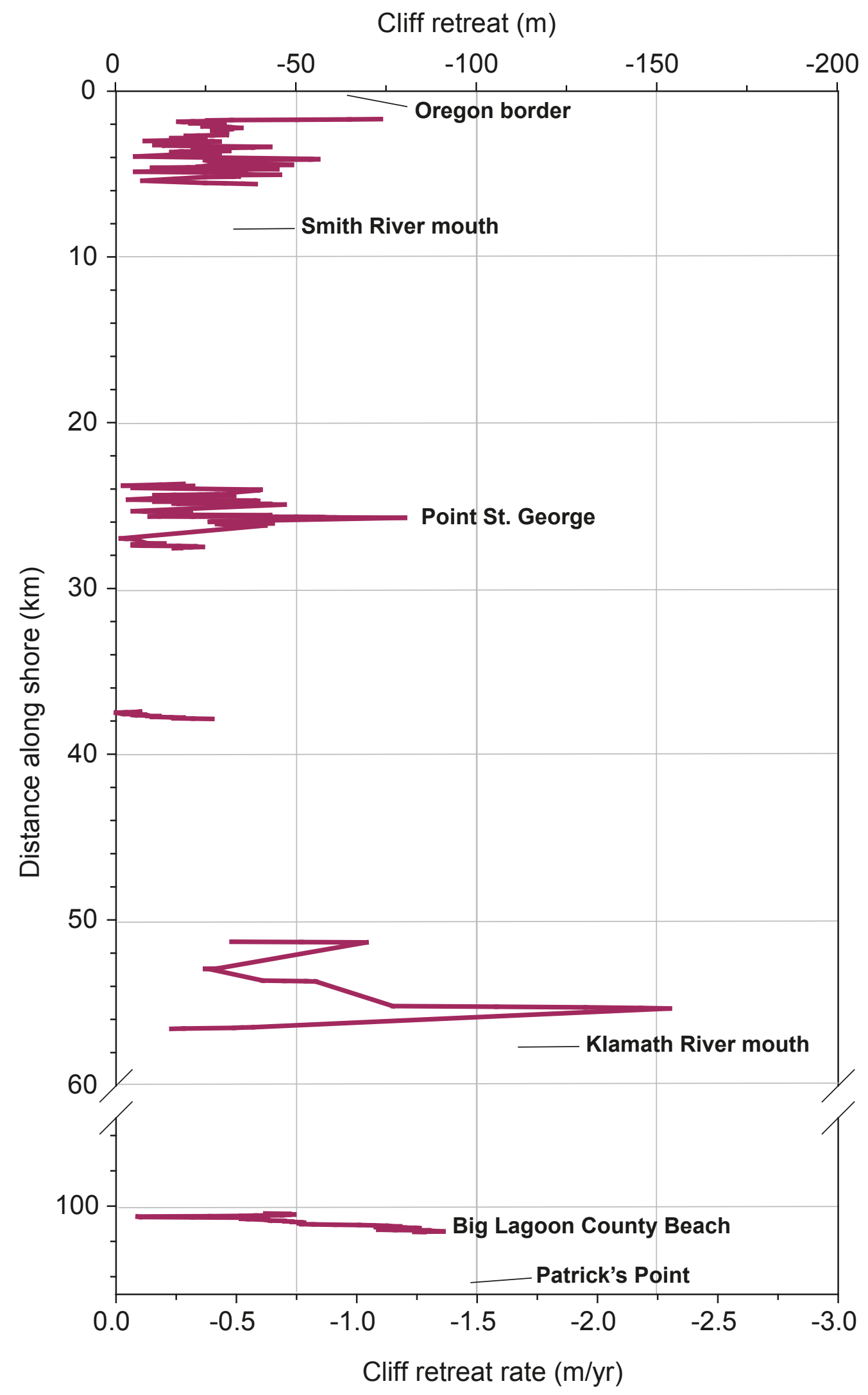

Figure 11. Cliff retreat rates and spatial distribution of rates for the Klamath region. The maximum rate in the Klamath region was $-167.9 \mathrm{~m} / \mathrm{yr}$ and was measured along a headland $2.6 \mathrm{~km}$ north of the Klamath River mouth (see Figure 10A). 

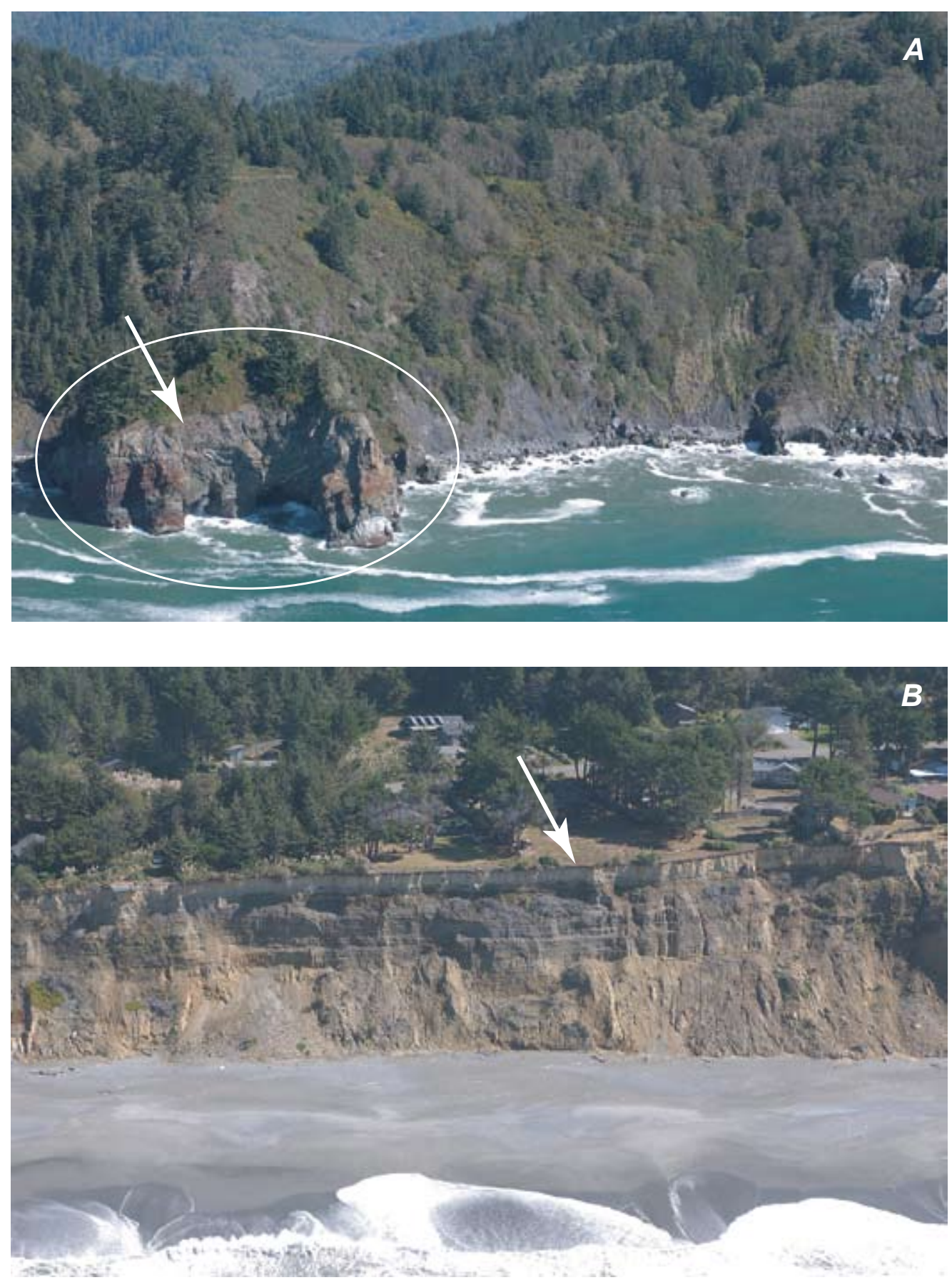

Figure 12. Photographs of regions of high cliff retreat in the Klamath region: A) the white circle highlights a small headland $\sim 2.6 \mathrm{~km}$ north of the Klamath River mouth (see Figure 10A) where the highest cliff retreat rates in the Klamath region $(-2.3 \mathrm{~m} / \mathrm{yr})$ were measured. The arrow points to the headland interpreted cliff edge; and B) rapidly retreating Quaternary strata at Big Lagoon County Beach (see Figure 10A) where the cliff has retreated over $75 \mathrm{~m}$ during the 70 -year time period of this study. The arrow point to the cliff edge. (Photos copyright (c) 2002-2007 Kenneth \& Gabrielle Adelman, California Coastal Records Project, www.californiacoastline.org). 


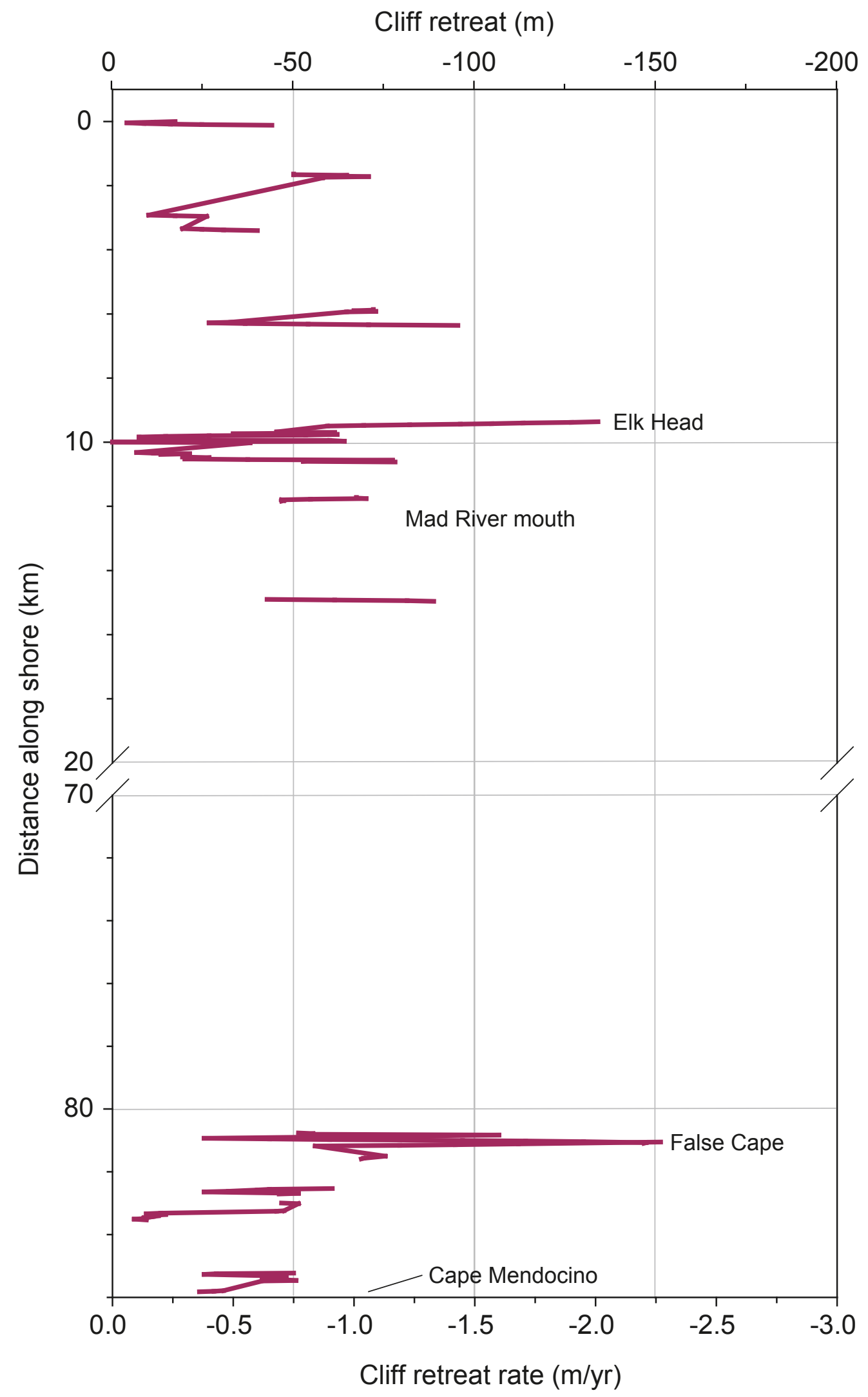

Figure 13. Cliff retreat rates and spatial distribution of rates for the Eureka region (see Figures 9 and 10A). 

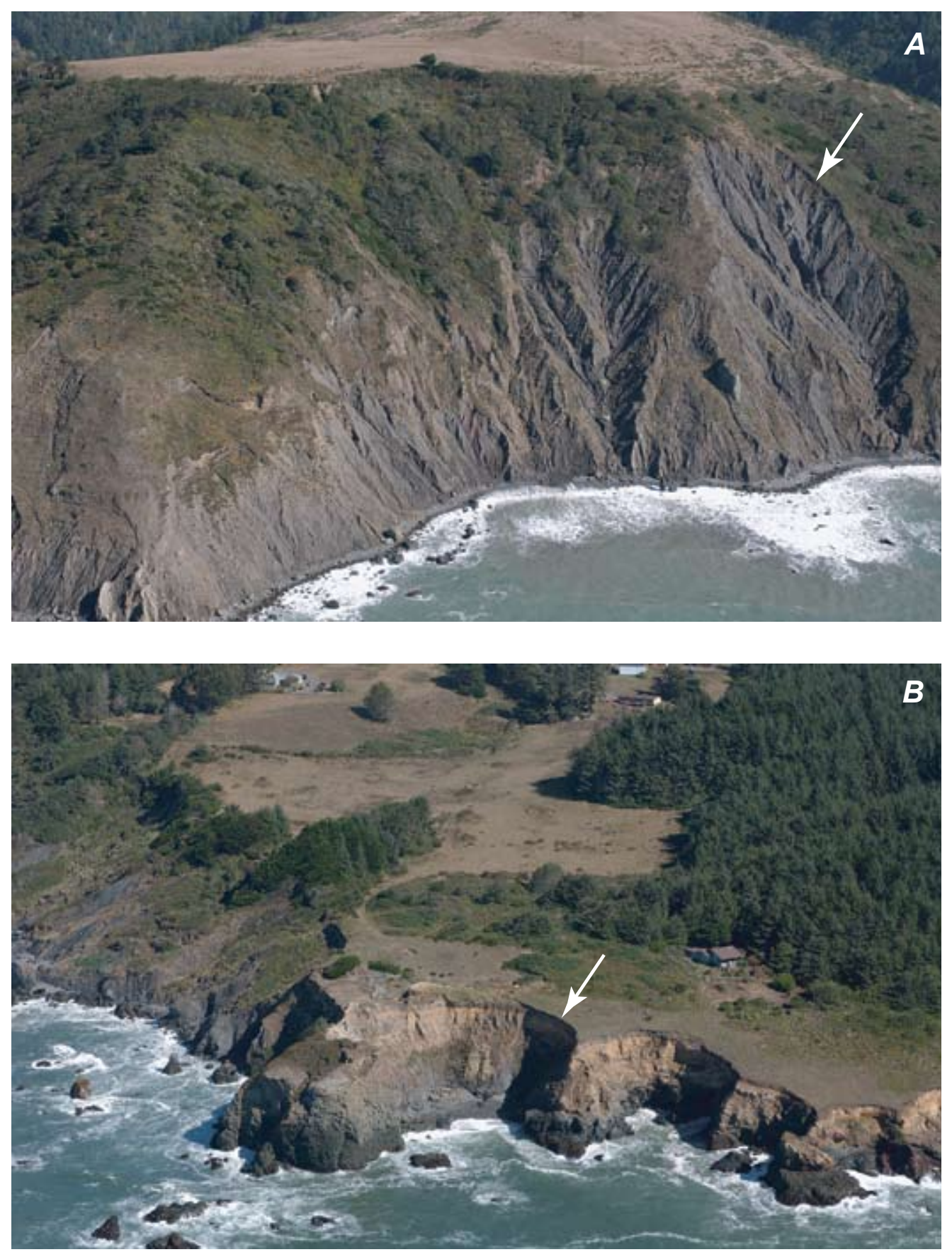

Figure 14. Areas of the highest cliff retreat rates in the Eureka region. The white arrows point to the feature interpreted as the cliff edge: A) loose, unconsolidated material in landslide complex is eroding rapidly via the formation of rills and gullies in the vicinity of False Cape, $7 \mathrm{~km}$ north of Cape Mendecino (see Figure 10A). The cliff at this site retreated over $150 \mathrm{~m}$ in a 70-year time period; and $\mathrm{B}$ ) rapid erosion of unlithified marine terrace deposits that overlie stronger bedrock material resulted in erosion rates $>2 \mathrm{~m} / \mathrm{yr}$ near Elk Cape (see Figure 10A). (Photos copyright (c) 2002-2007 Kenneth \& Gabrielle Adelman, California Coastal Records Project, www.californiacoastline.org). 


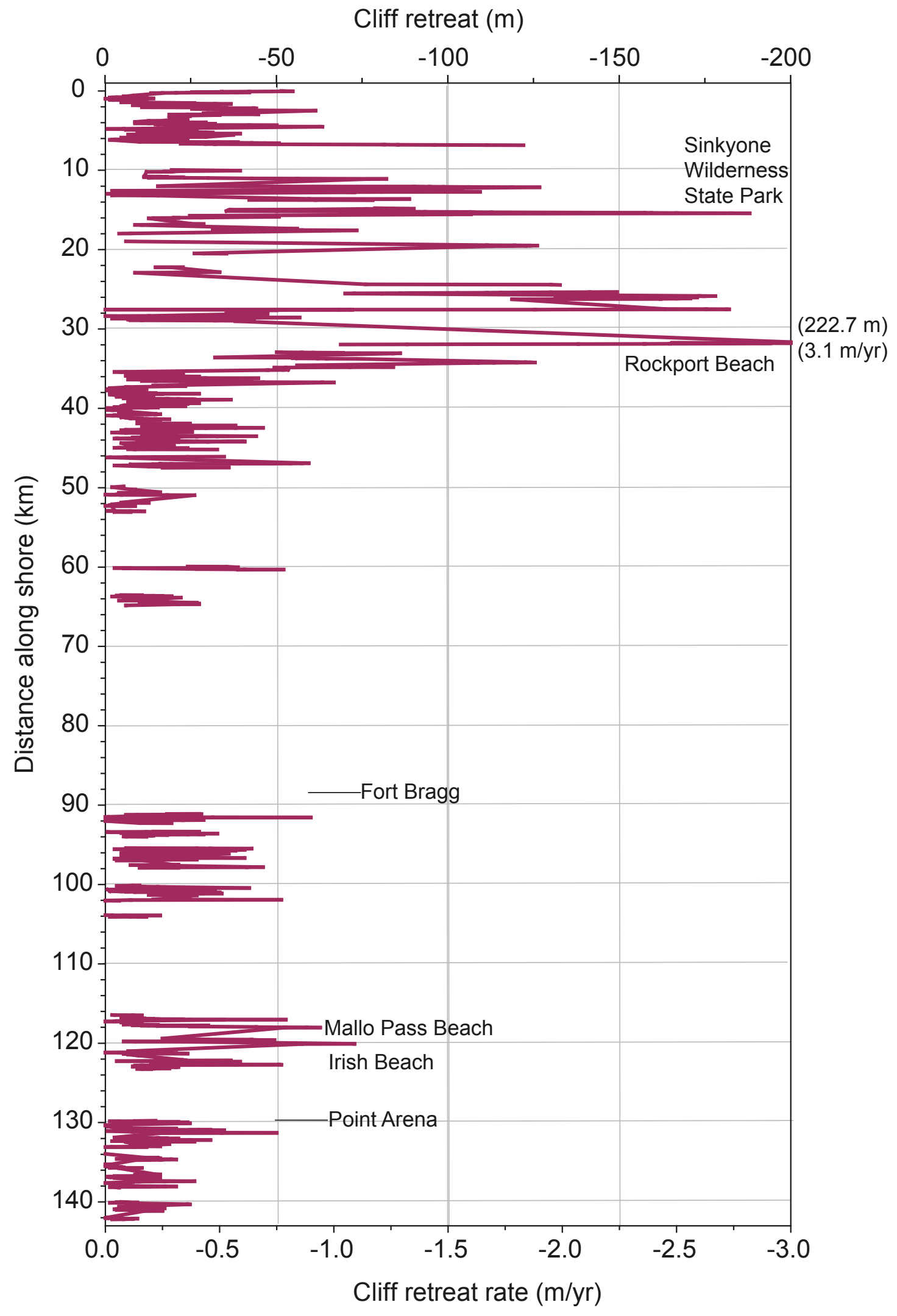

Figure 15. Cliff retreat rates and spatial distribution of rates for the Navarro region (see Figures 9 and $10 \mathrm{~A}$ for reference). 

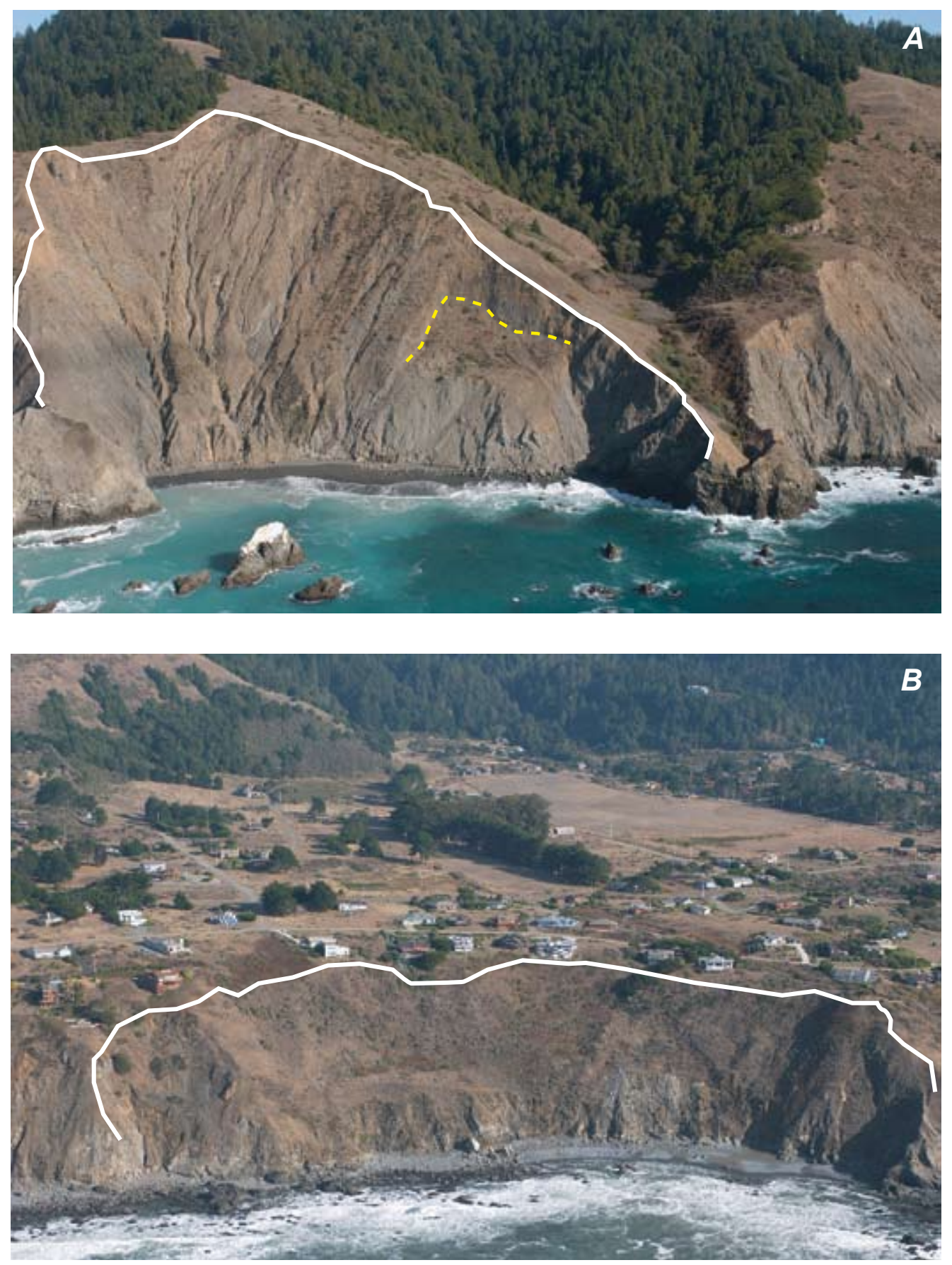

Figure 16. A) The highest rate in the state was measured at this location on the south end of Rockport Beach near Cape Vizcaino (see Figure 10A for reference). The white line delineates the headscarp of a large landslide, and the yellow dashed line shows a recently active slump within the landslide complex; B) this subdivision of Irish Beach, north of Point Arena (see Figure 10A) may be threatened if this landslide reactivates. The lack of vegetation at the base of the cliff indicates the lower slope is actively eroding. The white line provides a general outline of the large dormanat landslide. Measurements indicate that the average rate of retreat here is over $1 \mathrm{~m} / \mathrm{yr}$, and that the cliff top has eroded nearly $75 \mathrm{~m}$ in $\sim 70$ years. (Photos copyright (c) 2002-2007 Kenneth \& Gabrielle Adelman, California Coastal Records Project, www.californiacoastline.org). 


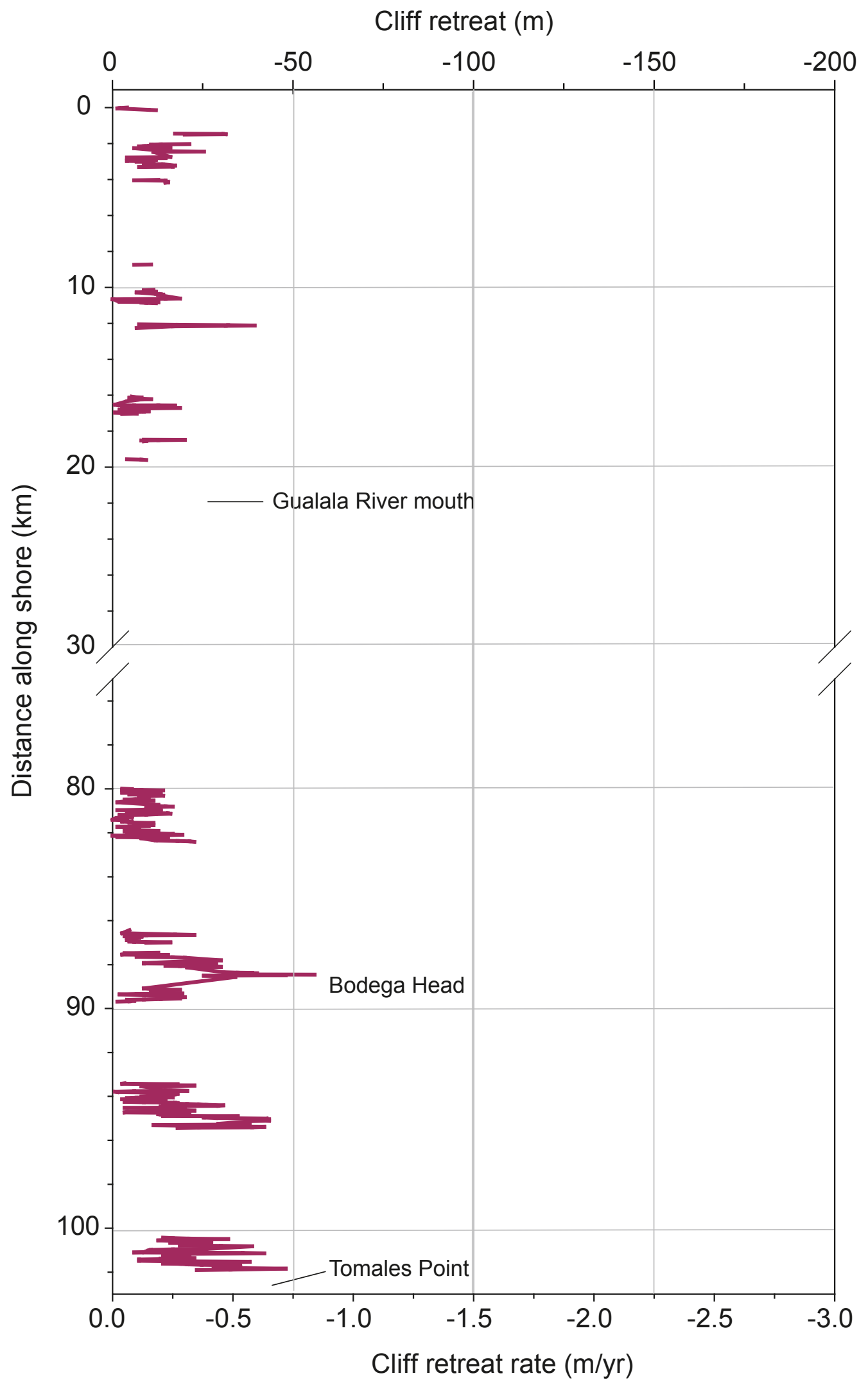

Figure 17. Cliff retreat rates and spatial distribution of rates for the Russian River region (see Figures 9 and $10 \mathrm{~A}$ for reference). 


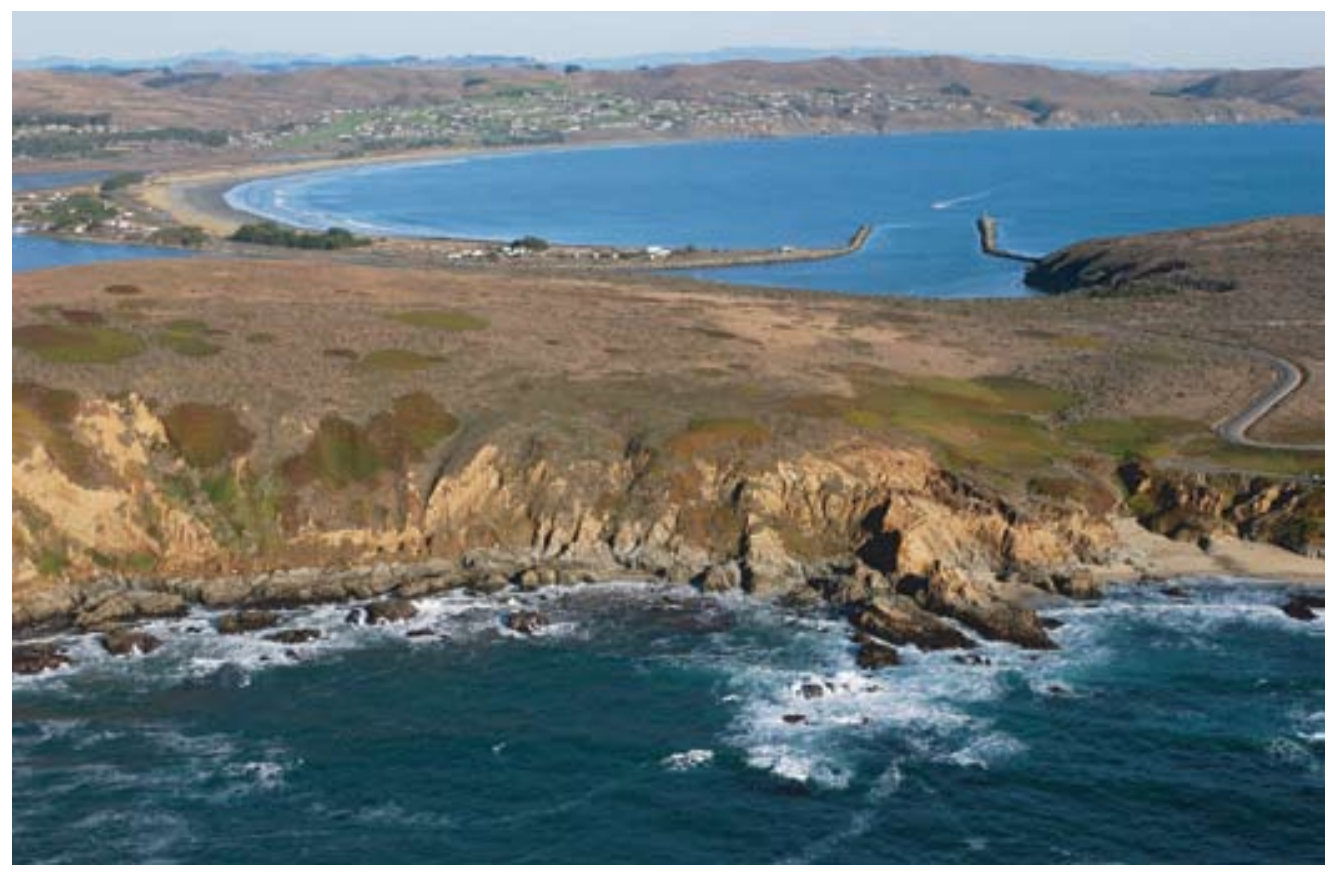

Figure 18. Unlithified sands overlie granitic bedrock at Bodega Head, which has the highest cliff retreat rates in the Russian River region. The maximum retreat in the region, $-60.5 \mathrm{~m}$, occurred at this location. The lighter, orange-colored material is composed of primarily sand whereas the gray material at the base of the cliff is granitic bedrock (Photo copyright (c) 2002-2007 Kenneth \& Gabrielle Adelman, California Coastal Records Project, www.californiacoastline.org).

and variable in geomorphology with both low bluffs and steep, higher relief cliffs. Areas of high hazard include the stretch of coast extending from Avila Beach to Pismo State Beach where some seawalls and riprap have been emplaced to protect coastal roads and buildings from cliff erosion. The average retreat rate for this region was $-0.2 \mathrm{~m} / \mathrm{yr}$, and the data are relatively continuous, measured along $80 \mathrm{~km}$ of coast (figure 29). The average amount of retreat was $11.3 \mathrm{~m}$, which is the lowest in the Central California region.

The highest rate measured in the Santa Barbara North region was $-1.3 \mathrm{~m} / \mathrm{yr}$, and was measured at Point Sal within steep bluffs formed in Quaternary sands overlying basaltic bedrock (figure 30), and bluff retreat occurs by slumping and gully formation in the unlithified sands.

Overall, the highest rates in Central California are concentrated at promontories or points, including Point San Luis, Point Sal, and Point Conception (figure 29).

\section{Southern California}

The Southern California section extends from El Capitan State Beach north of Santa Barbara to the Mexico border (figures 9 and 10C), comprising $400 \mathrm{~km}$ of coastline. The cliff retreat data for this section of the California coast is divided into five regions: Santa Barbara South, Santa Monica, San Pedro, Oceanside and San Diego. Southern California is dominated geomorphically by long linear stretches of beach that in some areas are backed by low-to-moderate relief cliffs. There are few areas of large deep-seated landslides, but where these do occur (i.e. Palos Verdes) they are usually the locations of the highest rates for each region. This is also the most populous coast and as a result is also the most engineered coastline in the state. In addition to numerous harbors, breakwaters, jetties and groins that disrupt the littoral flow of sand, large portions of the coast that are backed by cliffs have coastal protection structures. These efforts, which were employed to mitigate cliff retreat, have likely impacted the rates of cliff retreat, and likely contribute to the fact that the average retreat rate in Southern California is the lowest in the state $(-0.2 \mathrm{~m} / \mathrm{yr})$.

\section{Santa Barbara South Region}

The Santa Barbara South region begins at El Capitan Beach State Park and extends $111 \mathrm{~km}$ south to San Buenaventura State Beach (figures 9 and 10C). With the exception of the coast north of Santa Barbara, this is a highly developed and urbanized coastline and numerous coastal protection structures have altered the natural coastline and natural processes of cliff retreat. The coastal geomorphology is dominantly characterized by low- to moderate-relief bluffs with an average retreat rate of $-0.2 \mathrm{~m} / \mathrm{yr}$, and an average amount of retreat of $13.3 \mathrm{~m}$ (table 4 ). Rates were measured along a total of $17 \mathrm{~km}$ in this region.

Overall, the rates were relatively low (figure 31 ), and the maximum retreat measured was $63 \mathrm{~m}$, a rate of -1.0 


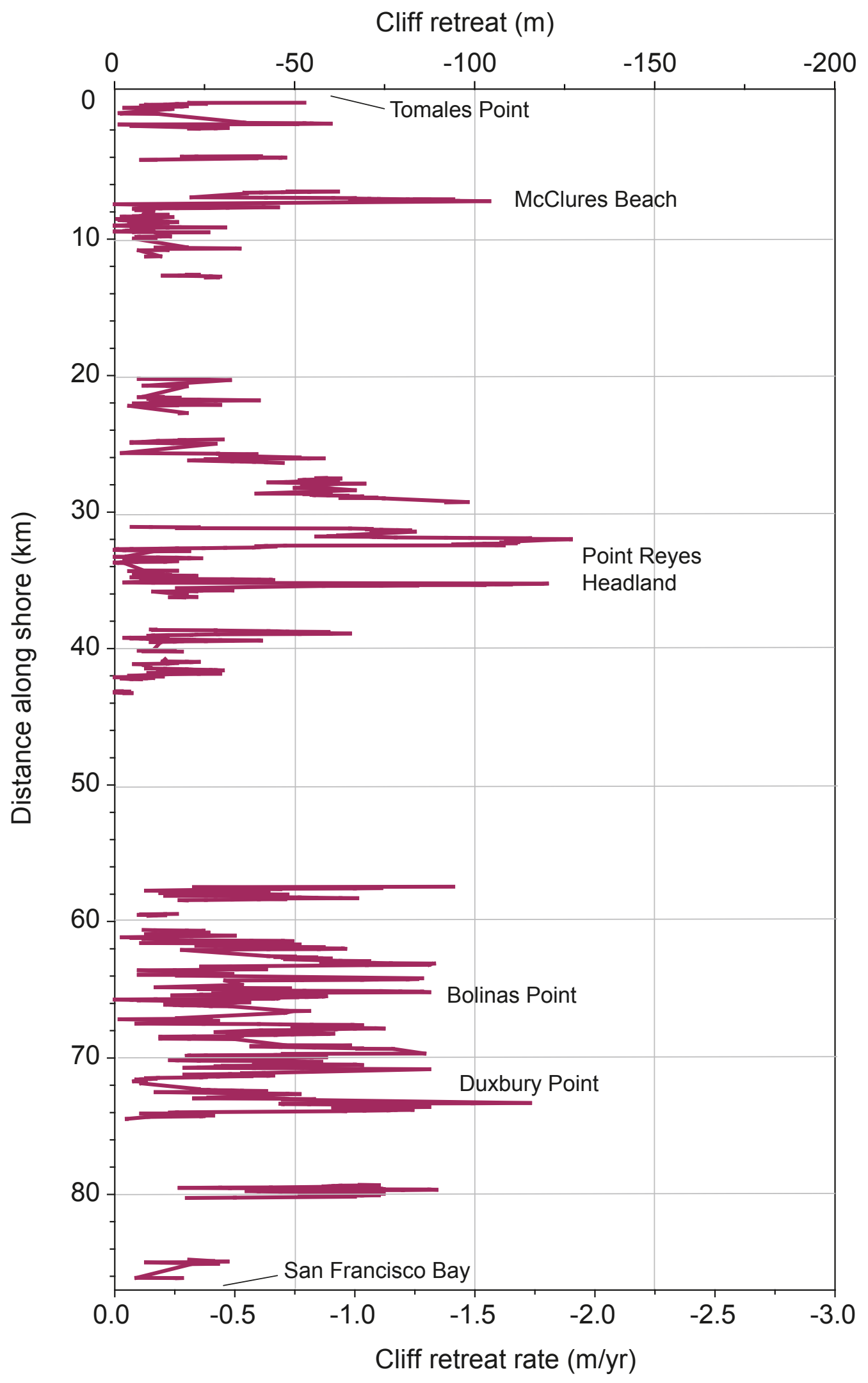

Figure 19. Cliff retreat rates and spatial distribution of rates for the San Francisco North region (see Figures 9 and 10B for reference). 


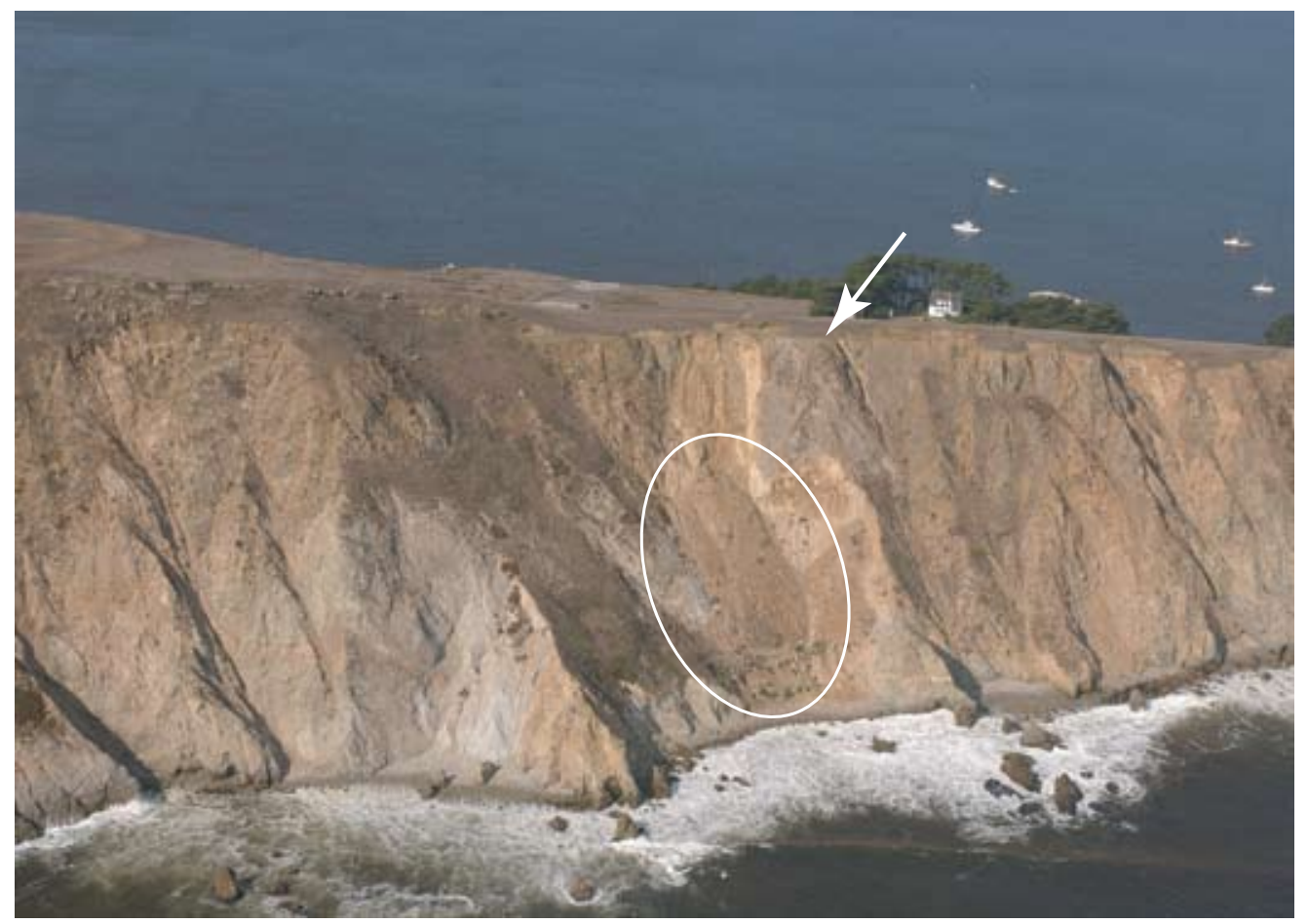

Figure 20. Poorly lithified marine sediments overlie granitic and metamorphic rocks at Point Reyes (see Figure 10B). The maximum retreat in the San Francicso North region, $-138.7 \mathrm{~m}$, was measured at this location. The circle indicates a large scree slope, indicative of the actively failing slope. The arrow points to the edge of the cliff. (Photo copyright (c) 2002-2007 Kenneth \& Gabrielle Adelman, California Coastal Records Project, www.californiacoastline.org).

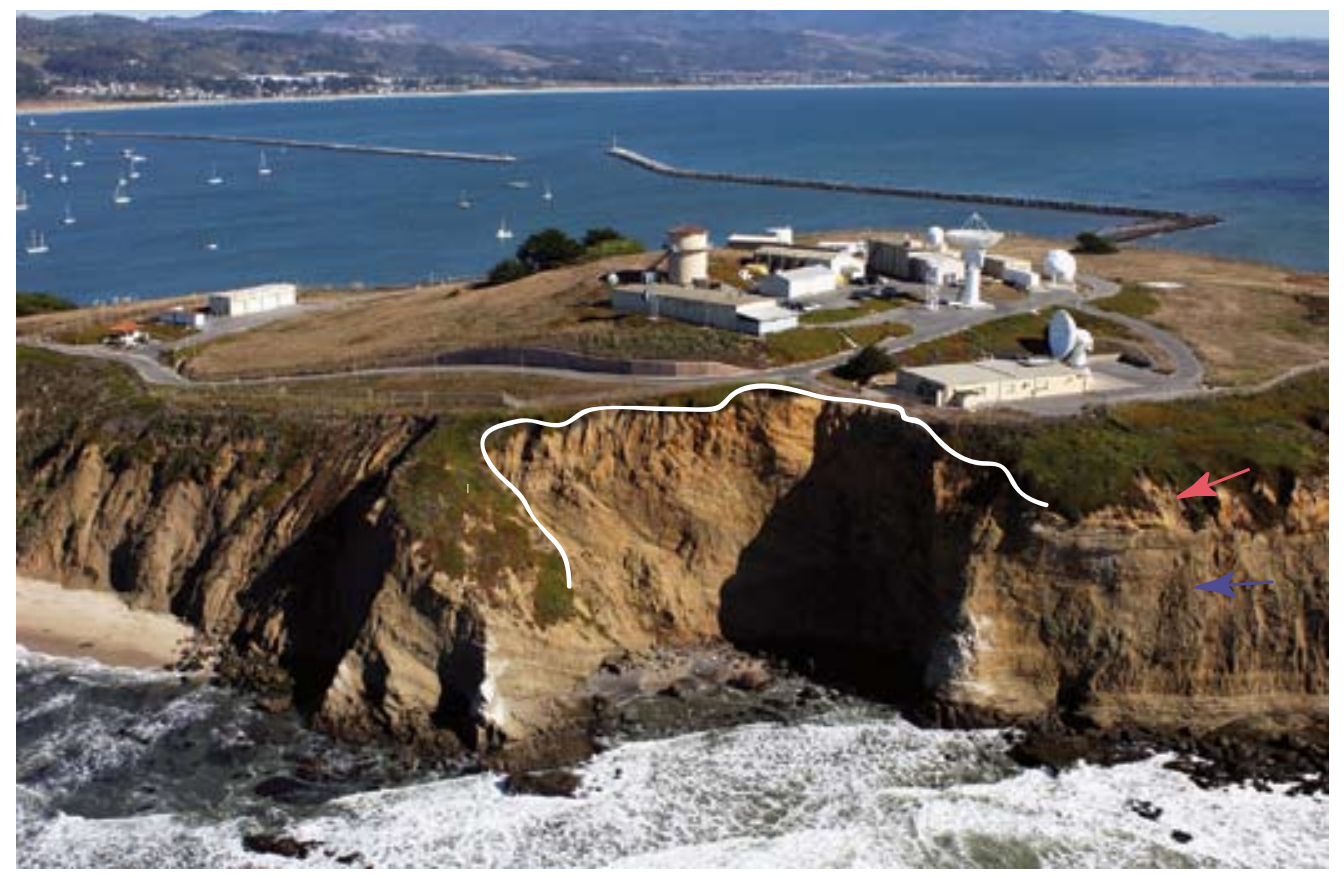

Figure 21. The headland at Pillar Point is composed of sands and gravels (red arrow) overlying mudstone (blue arrow). The poorly lithified sand and gravel are eroding rapidly, and as a result the cliff has retreated $210 \mathrm{~m}$ over a 70 -year period. The white line outlines the head scarp of the actively eroding portion of the cliff. (Photo copyright (c) 2002-2007 Kenneth \& Gabrielle Adelman, California Coastal Records Project, www.californiacoastline.org). 


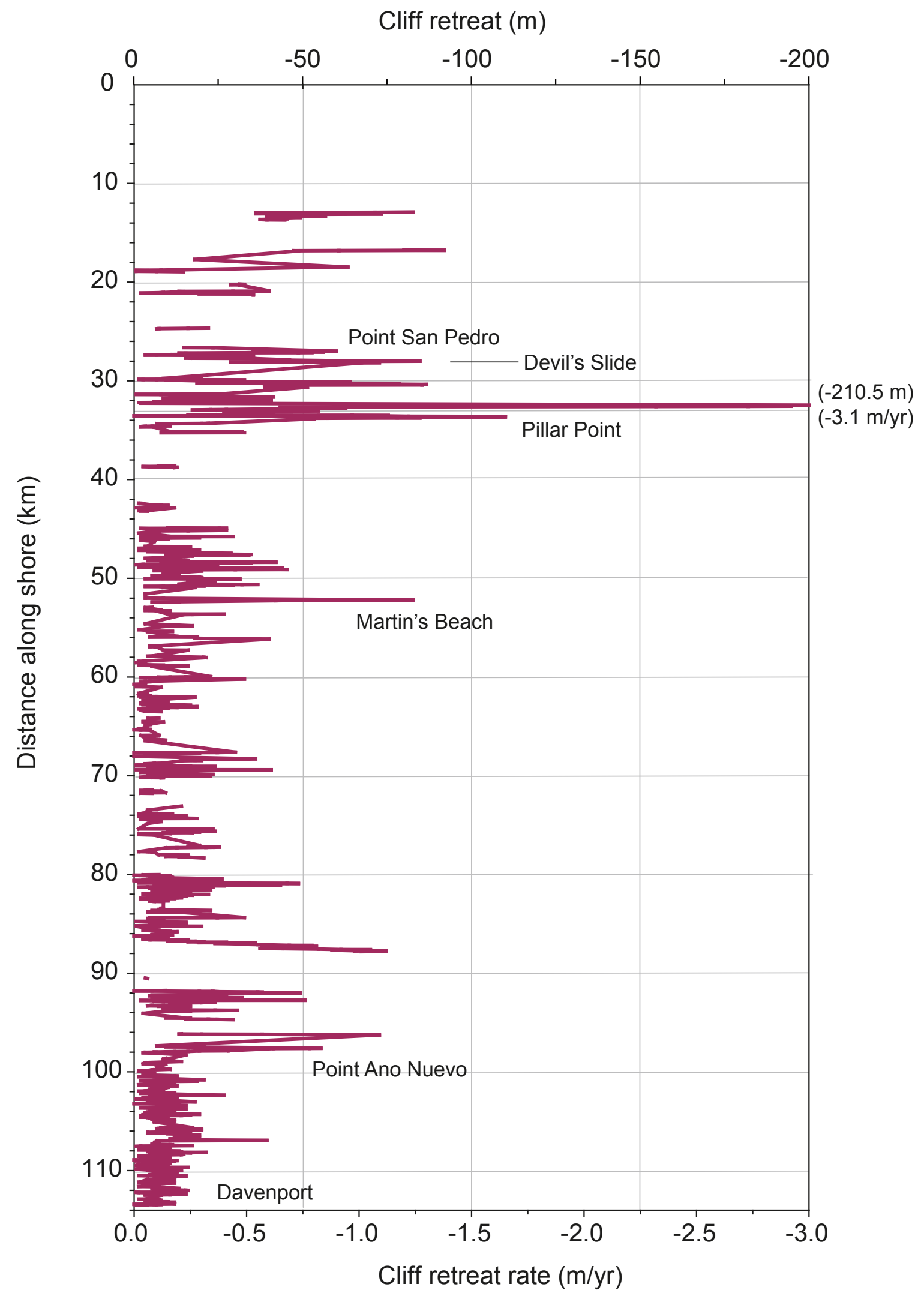

Figure 22. Cliff retreat rates and spatial distribution of rates for the San Francisco South region (see Figures 9 and 10B for reference). 


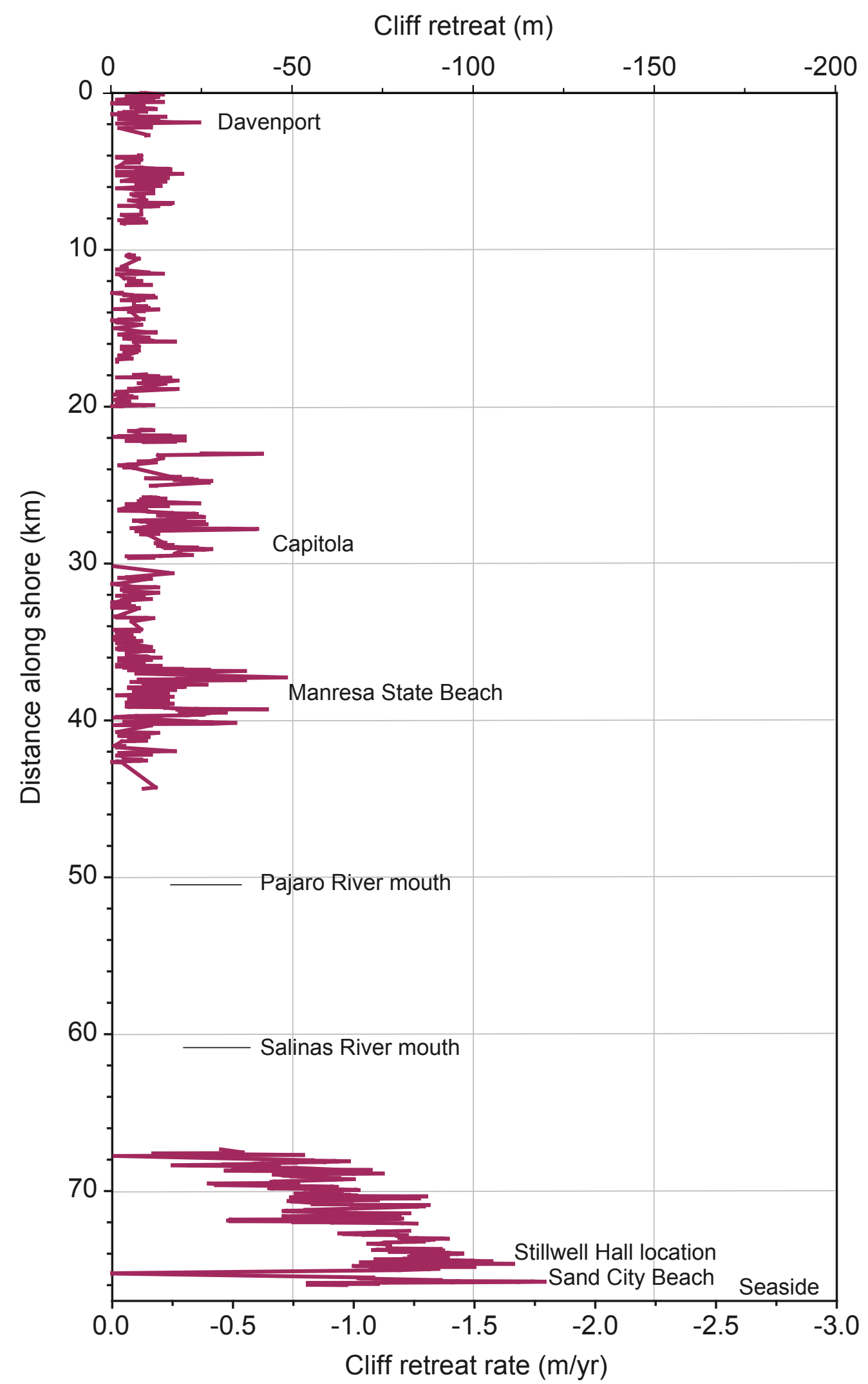

Figure 23. Cliff retreat rates and spatial distribution of rates for the Monterey Bay region (see Figures 9 and 10B for reference). 

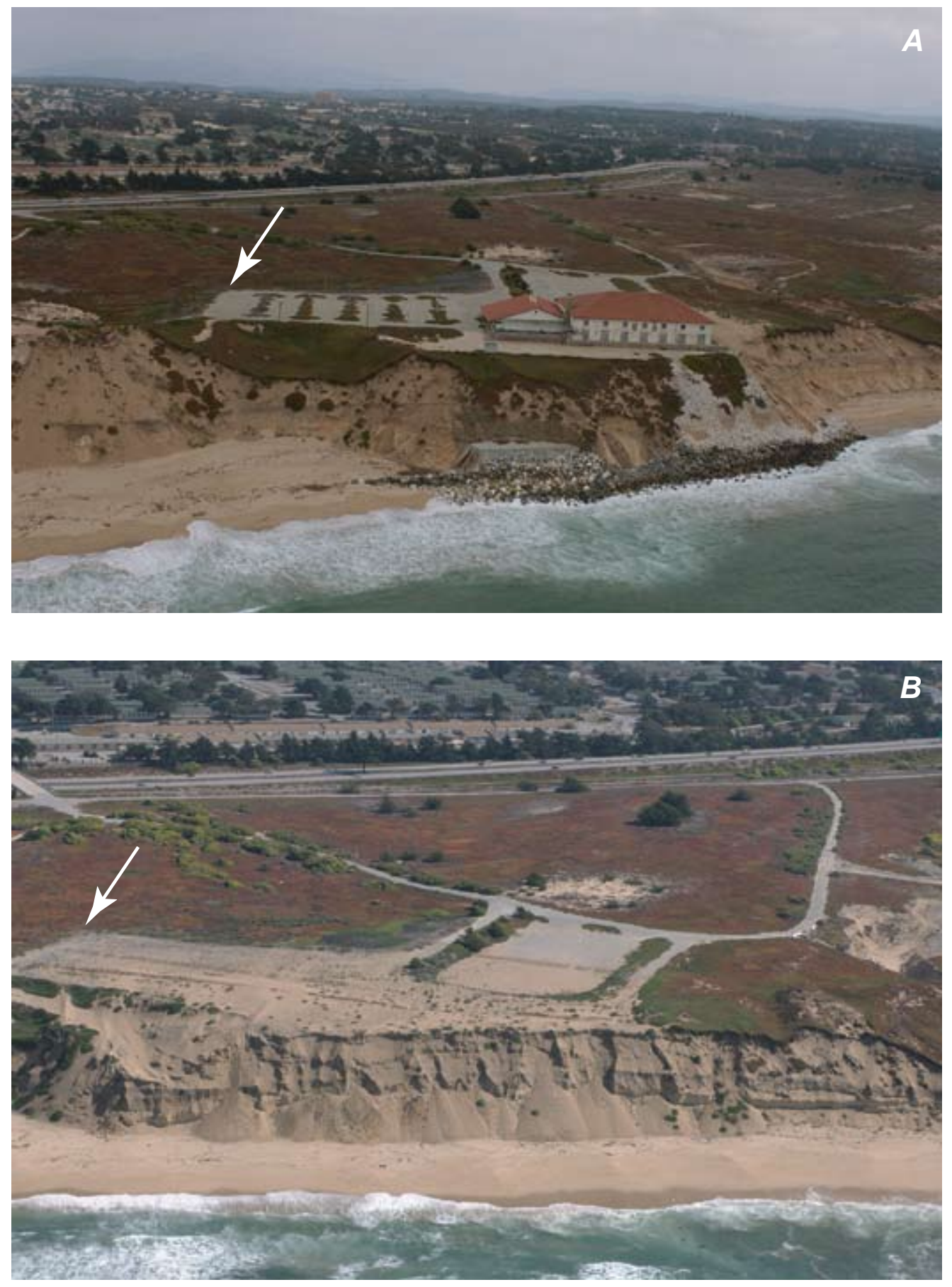

Figure 24. Stillwell Hall, a soldier's club on the Fort Ord military base, was threatened by rapid erosion of the bluffs for years before being removed in 2004: A) Stillwell Hall in 2002 with riprap revetment along base of bluff. The arrow points to a corner of the parking lot for reference; and B) the former site of the hall in 2005. The arrow points to the same location as in A. The amount of retreat measured over 70 years in this area was just over $116 \mathrm{~m}$. (Photos copyright (c) 2002-2007 Kenneth \& Gabrielle Adelman, California Coastal Records Project, www.californiacoastline.org). 
$\mathrm{m} / \mathrm{yr}$, which was measured in the vicinity of Arroyo Burro Beach (locally known as Hendry's Beach). The cliffs in this area are fronted by a very narrow beach that provides little protection from waves (figure 32A). Undercutting and notching of the base of the cliffs leads to eventual collapse. Lookout County Park is also an area of higher erosion in the Santa Barbara South region (figure 31). Poorly lithified sedimentary strata at this location are protected at the base by bulkheads and revetment to help protect both a railroad grade and highway (figure 32B), although the bluffs are still undergoing rapid erosion driven by subaerial processes.

\section{Santa Monica Region}

The Santa Monica region is $91 \mathrm{~km}$ long and extends from $22 \mathrm{~km}$ north of Point Dume to Point Vincente (Palos Verdes) (figures 9 and 10C). The geomorphology of the coast is variable, and includes steep coastal slopes along the Malibu coast in the north and the southern portion of the region near the Palos Verdes Peninsula, and coastal lowlands or wide beaches backed by cliffs in the central part of the region. The coast is extensively developed, and coastal protection structures are commonplace along the cliffed sections of coastline. The average retreat rate, measured along $22 \mathrm{~km}$ of coastline, was $-0.3 \mathrm{~m} / \mathrm{yr}$, the highest in Southern California (table 4), and the average amount of retreat was $17.9 \mathrm{~m}$.

In general, the highest rates in the Santa Monica region are associated with deep failures on tall, steep coastal cliffs, such as those at Leo Carillo State Beach Park, Point Dume, and the Big Rock Mesa landslide at Big Rock Beach (figures 10C and 33). The steep cliffs above the beach along the Malibu coast are also undergoing rapid retreat. The highest retreat rate $(-1.8 \mathrm{~m} / \mathrm{yr})$ was at the site of the Big Rock Mesa landslide where the 70-year amount of erosion at Big Rock Mesa was -115 m (figure 34). The cliffs here are formed within highly sheared and fractured rocks associated with the Malibu Coast fault zone, and are prone to frequent failures (Orme, 2005).

\section{San Pedro Region}

The San Pedro region extends approximately $87 \mathrm{~km}$ from Point Vincente to Dana Point (figures 9 and 10C). Large extents of this coast are either engineered (including Los Angeles Harbor) are composed of coastal lowlands, or both. Therefore cliff retreat data are highly discontinuous (figure 35). Cliff retreat was measured along small portions of the Palos Verdes Peninsula in the north and along the coast south of Newport Bay, resulting in a total of 10 $\mathrm{km}$ of data coverage for the region. The average retreat rate along these sections of coast was $-0.2 \mathrm{~m} / \mathrm{yr}$, and the average amount of erosion was $-9.8 \mathrm{~m}$, the lowest in the state.

The highest cliff retreat within the San Pedro region was measured at Point Fermin, just north of Los Angeles
Harbor (figures 10C and 35), where the cliff edge has retreat $-64 \mathrm{~m}$ in the $\sim 70$-years time period of this study, resulting in an average retreat rate of $-1.0 \mathrm{~m} / \mathrm{yr}$. Here, the tall cliffs at the Sunken City landslide complex are undergoing rapid retreat where the seaward dip of the cliff-forming sedimentary units make this area very susceptible to landslides (figure 36). Other areas of rapid retreat in the region are Crystal Cove State Beach and Monarch Point, where the retreat is related to a series of small landslides in weak cliffs.

\section{Oceanside Region}

The Oceanside region extends $86 \mathrm{~km}$ from Dana Point to Point La Jolla in the south (figures 9 and 10C). The cliff retreat data for this region cover $40 \mathrm{~km}$ of coastline, and are more continuous (figure 37) than other Southern California regions, primarily because of the well-defined and relatively continuous marine terrace cliffs of this area. The average amount of cliff retreat was $-12 \mathrm{~m}$, and the average retreat rate was $-0.2 \mathrm{~m} / \mathrm{yr}$, similar to the average rates for the other regions in Southern California.

The maximum cliff retreat $(-110 \mathrm{~m})$, as well as the highest rates in the region $(-1.7 \mathrm{~m} / \mathrm{yr})$ were along San Onofre Beach (figure 37 and table 5). The beach in front of the poorly lithified bluffs is relatively wide (figure 38A), but prior to the large influx of sediment from the construction of the nearby San Onofre Nuclear Generating Station from 1964 to 1985 , the beach was much narrower and provided little protection from waves (Flick, 2005). Rates have likely slowed in the latter part of the analysis period, although there is visual evidence that there is active erosion occurring through gullying and shallow slumping of the cliff material (figure 38A).

Other areas where the cliffs have eroded nearly $100 \mathrm{~m}$, and thus have high retreat rates include Poche Beach, Torrey Pines State Beach, and Torrey Pines City Beach (figure 37). The tall cliffs above Poche Beach are now isolated from wave action by a wide beach and road. Therefore the high rates here are either driven solely by terrestrial processes, or occurred early in the analysis period prior to the widening of the beach and emplacement of the road. The cliffs at Torrey Pines City Beach (figure 38B) are eroding by a combination of marine and terrestrial processes; the narrow beach and poorly lithified geologic material forming the cliff combine to make this a very active section of coast.

\section{San Diego Region}

The San Diego region extends for approximately 48 $\mathrm{km}$ from Point La Jolla to the Mexico border (figures 9 and 10C). Our data do not extend further south than the entrance to San Diego Harbor (figure 39), primarily because south of the harbor the coast is characterized by linear beaches with no backing cliff or bluff. The coastline in the 


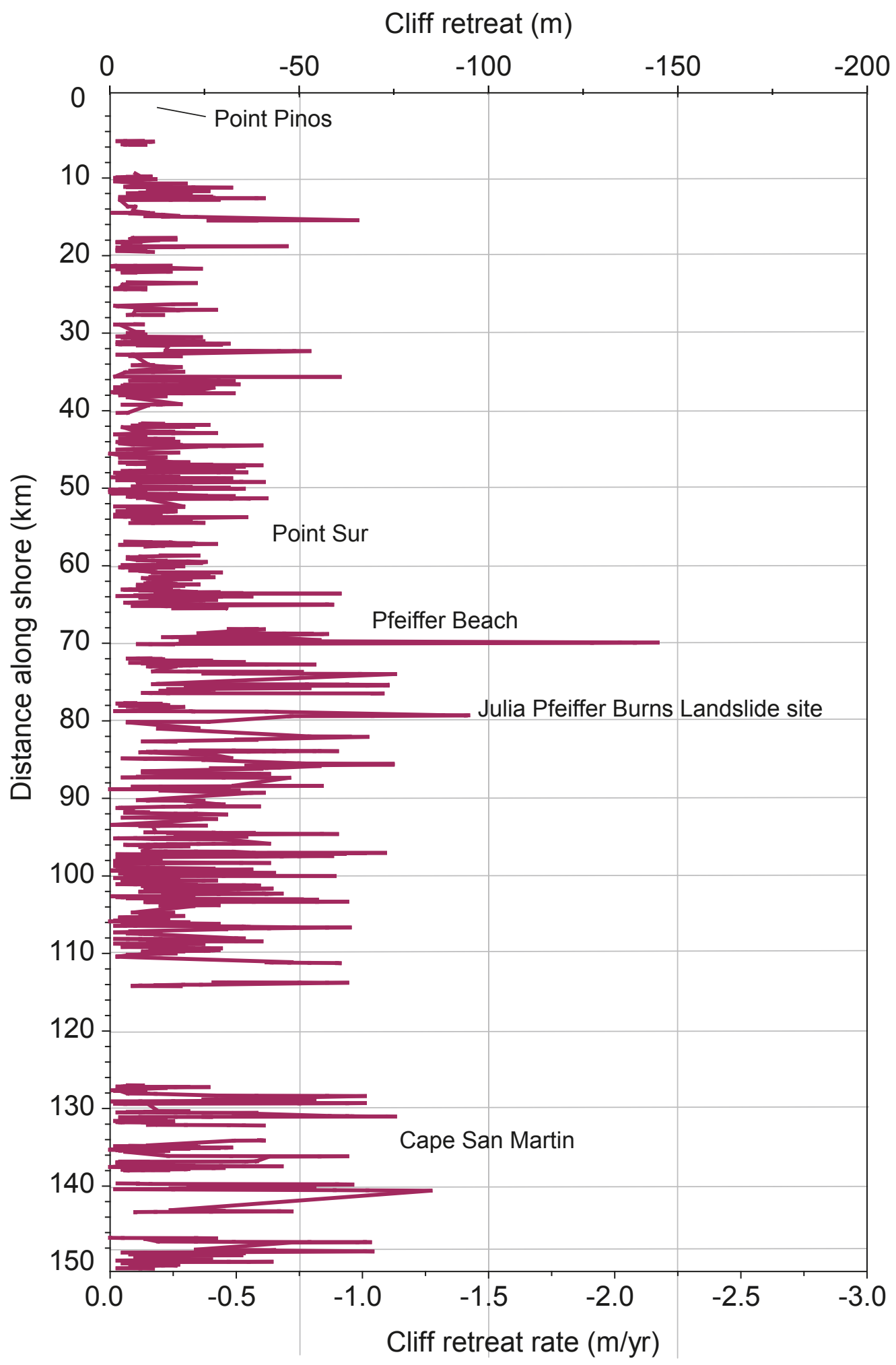

Figure 25. Cliff retreat rates and spatial distribution of rates for the Big Sur region (see Figures 9 and 10B for reference). 

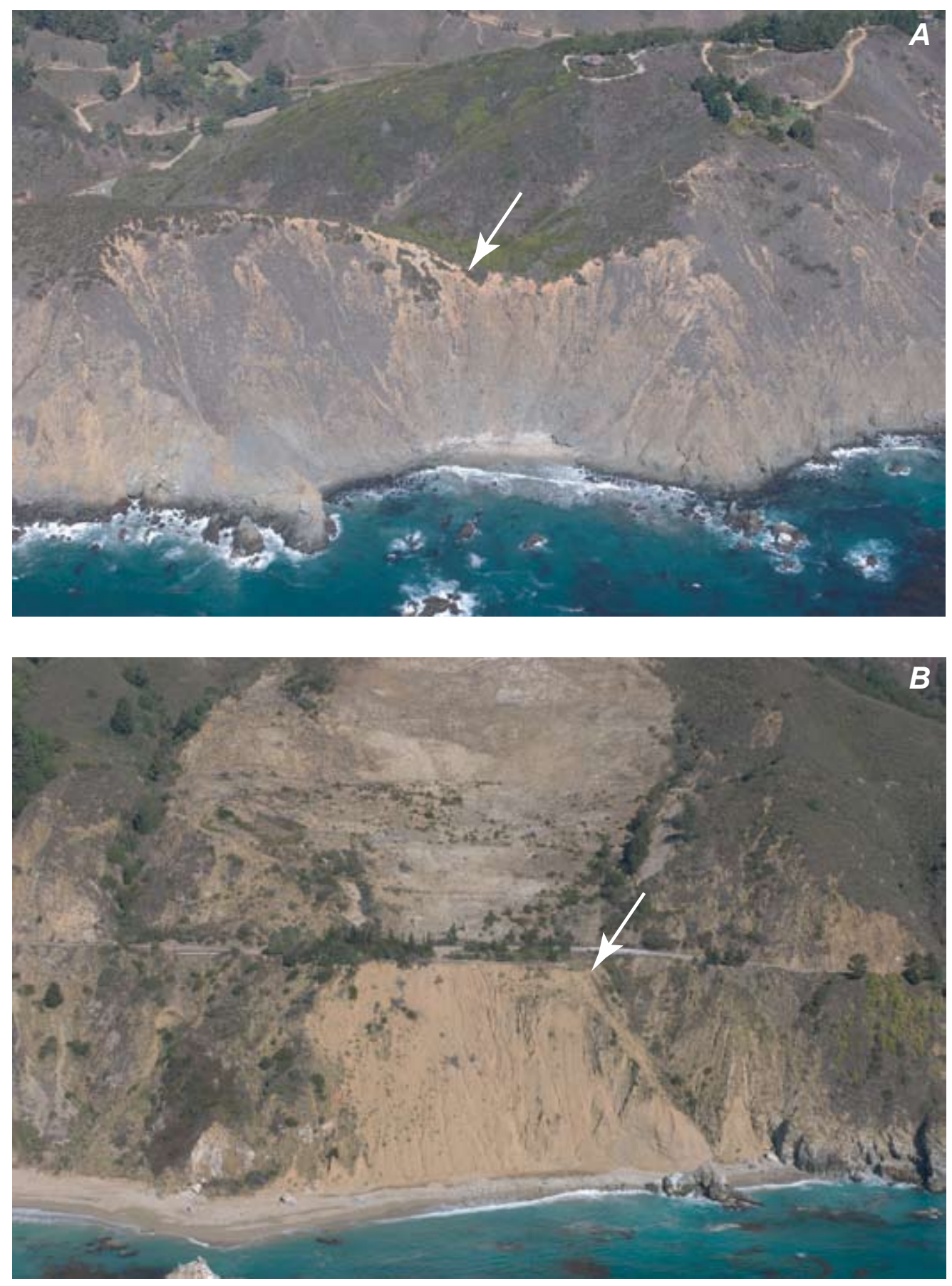

Figure 26. A) This large coastal landslide just south of Pfeiffer Beach (see Figure 10B) eroded nearly $150 \mathrm{~m}$ over the 70-year period of this study, and is the site of the maximum slope retreat in the Big Sur region. The arrow shows the top edge of the slope with which the retreat measurements were made; and B) The site of the Julia Pfeiffer Burns landslide, which was retreating at an average rate of $-1.4 \mathrm{~m} / \mathrm{yr}$. However, this area was not part of an active slide until 1983. The arrow points to the landward edge of the loose landslide material that now defines the edge of the active slope. The upper part of the landslide can be seen in the upper portion of the photo, and shows there is still lack of vegetative cover more than 20 years after the slide originally failed. (Photo copyright (c) 2002-2007 Kenneth \& Gabrielle Adelman, California Coastal Records Project, www. californiacoastline.org). 


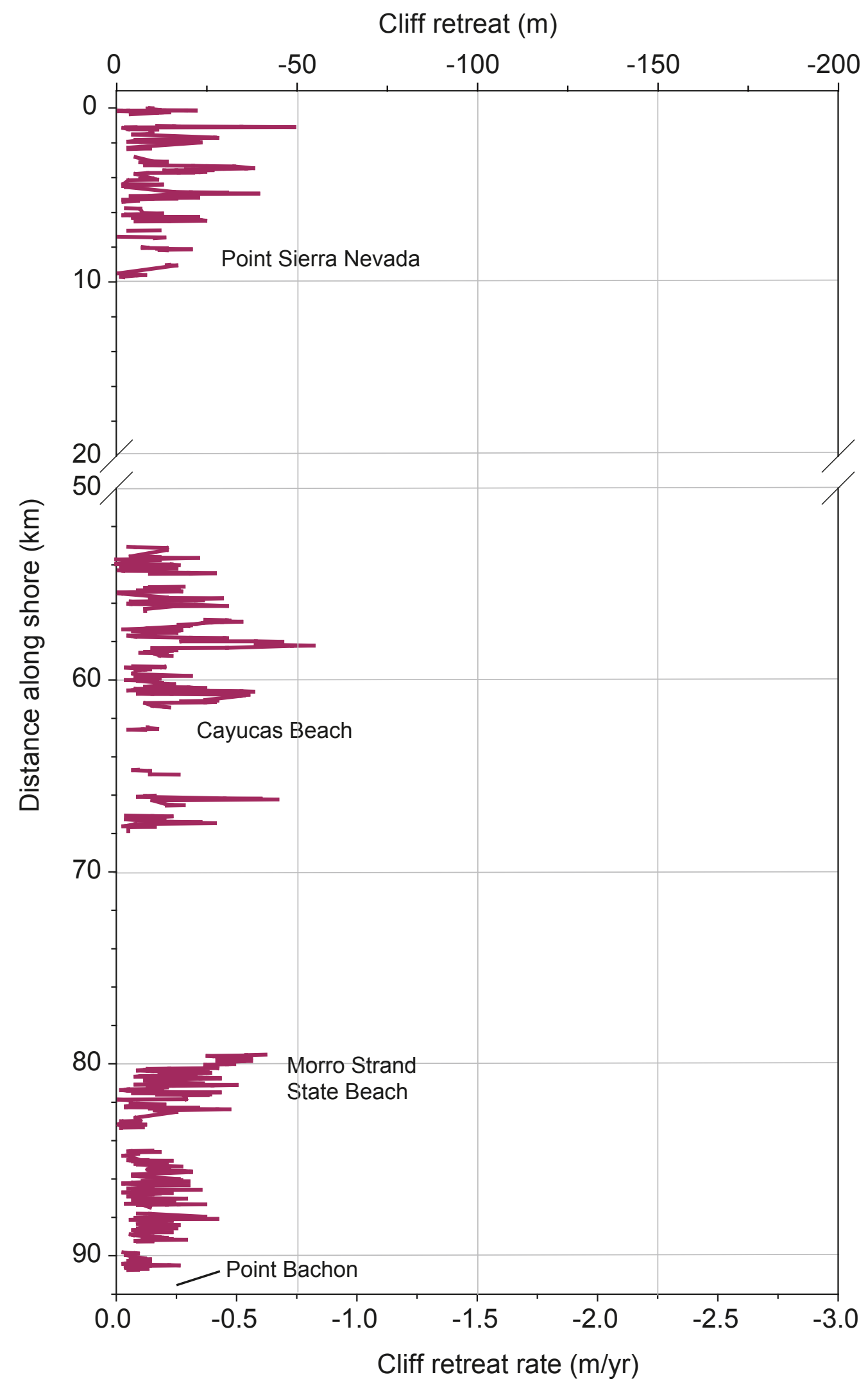

Figure 27. Cliff retreat rates and spatial distribution of rates for the Morro Bay region (see Figures 9 and $10 \mathrm{~B}$ for reference). 


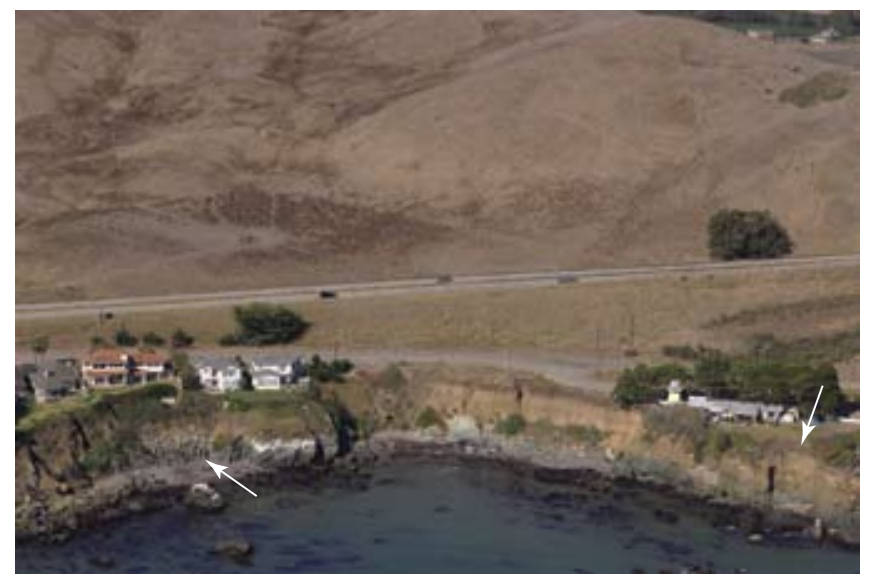

Figure 28. Retreat of the low coastal cliff threatens these homes near Cayucos Beach (see Figure 10B for reference). The cliff retreat at this location was $33 \mathrm{~m}$ over the 70 -year time period of this study. The left arrow points to riprap at the base of the bluff, and the right arrow points to a portion of actively eroding bluff. (Photo copyright (c) 2002-2007 Kenneth \& Gabrielle Adelman, California Coastal Records Project, www.californiacoastline. org).

San Diego region north of San Diego Harbor consists of rocky coast with small pocket beaches, low-relief linear beaches, and cliffs fronted by narrow beaches. The average amount of cliff retreat was $-13.3 \mathrm{~m}$, and the retreat rate for the $10 \mathrm{~km}$ measured in this region was $-0.2 \mathrm{~m} / \mathrm{yr}$.

The cliffs along Point Loma are steep and very tall, reaching over $90 \mathrm{~m}$ in some areas. The maximum retreat was almost $100 \mathrm{~m}$ over the 70-year analysis, and the highest rate of cliff retreat, $-1.6 \mathrm{~m} / \mathrm{yr}$ (table 5), was measured along a remote stretch of coast near the Point Loma Nazarine College (figure 40). In this area, there is little or no fronting beach and thus no basal protection from wave attack. The cliff at water level is composed of relatively resistant sedimentary strata (Flick, 2005) but is capped by soft, unconsolidated material that erodes via deep gully formation. In general, the rates measured for this region agree with those published by Moore et al. (1999) and Young and Ashford (2006).

\section{SUMMARY OF CLIFF RETREAT}

According to a recent study by the California Department of Boating and Waterways and the State Coastal Conservancy (2002) the state of California has $1,860 \mathrm{~km}$ of open ocean coastline. Of this, $1,340 \mathrm{~km}$ has some type of coastal cliff. The remaining sections of coast are generally coastal lowlands formed near the outlets of rivers and streams. In this report, long-term rates of coastal cliff retreat were provided for $353 \mathrm{~km}$ of the total length of cliffed coastline. For this analysis, gaps in either the lidar data or T-sheets, or the absence of a definable cliff edge in high-relief areas, resulted in a lack of two cliff edges over $74 \%$ of the coast characterized as cliffed or rocky. Therefore, in this report we present long-term cliff retreat rates for $19 \%$ of the total California coast, and $26 \%$ of California's cliffed coast.

The Eureka region in Northern California had the highest regionally-averaged retreat rate $(-0.7 \mathrm{~m} / \mathrm{yr})$ in the state, which translates to an average retreat amount of $53 \mathrm{~m}$ over the 70-year time period of this study. However, the rates were measured along a short length of coast $(3 \mathrm{~km})$ due to data gaps and may not be as representative as the other analysis regions. In general, the longer extents of continuous rates were measured in areas with well-developed and relatively continuous elevated marine terraces, such as the Santa Barbara North and Oceanside regions. Even in regions with lower average trends, there are clearly specific areas of coastline with high erosion rates, or "hotspots". In many locales, these hotspots present a high hazard to coastal development. Even in areas where the retreat rates are not exceptionally high, small amounts of cliff retreat may threaten homes and other community infrastructure.

The average 70-year cliff retreat rates for California were highest in the Santa Monica region in Southern California (-0.3 m/yr, or $18 \mathrm{~m}$ of retreat), the San Francisco North region in Central California $(-0.5 \mathrm{~m} / \mathrm{yr}$, or $36 \mathrm{~m}$ of retreat) and the Eureka region in Northern California (-0.7 $\mathrm{m} / \mathrm{yr}$, or $53 \mathrm{~m}$ of retreat). The maximum retreat in the state was $223 \mathrm{~m}$ of erosion in the Navarro region at the location of a large, deep-seated coastal landslide. The second highest amount of retreat, $210 \mathrm{~m}$, was on the north-facing side of a large coastal headland in the San Francisco South region.

Coastal cliff retreat rates are directly related to the geomorphology and geologic processing driving the retreat of the coast. As a result, the highest rates occurred along high-relief coastal slopes and were associated with large, deep-seated coastal landslide complexes. Thus, Northern California had the highest average retreat rates. In both the Santa Monica and San Pedro regions in Southern California, the highest rates were measured at specific sites of large landslides. For most other regions, the rates were highest where the cliff is composed of weaker geologic materials, such as Monterey Bay. Coastal protection structures likely influence the rates presented in this report. However, because most structures were emplaced in the time period covered by this analysis (1930s to 1998/2002), it is not possible to quantitatively evaluate the extent of their effect.

The geomorphic influences on the rates of cliff retreat are also evident in the relationship between promontories and headlands and high rates of retreat. In almost all of the analysis regions, the rates were consistently high in focused areas including Point Arena, Bodega Head, Point Reyes, Pillar Point, Point Sal and Point Loma. This relationship was more frequently true in Northern and Central California where the coastline is more crenulated, and thus has a higher density of headlands and embayments. The focusing of wave energy at headlands is likely driving these high rates, and underscores the importance of wave energy and water level on processes of coastal cliff retreat. 


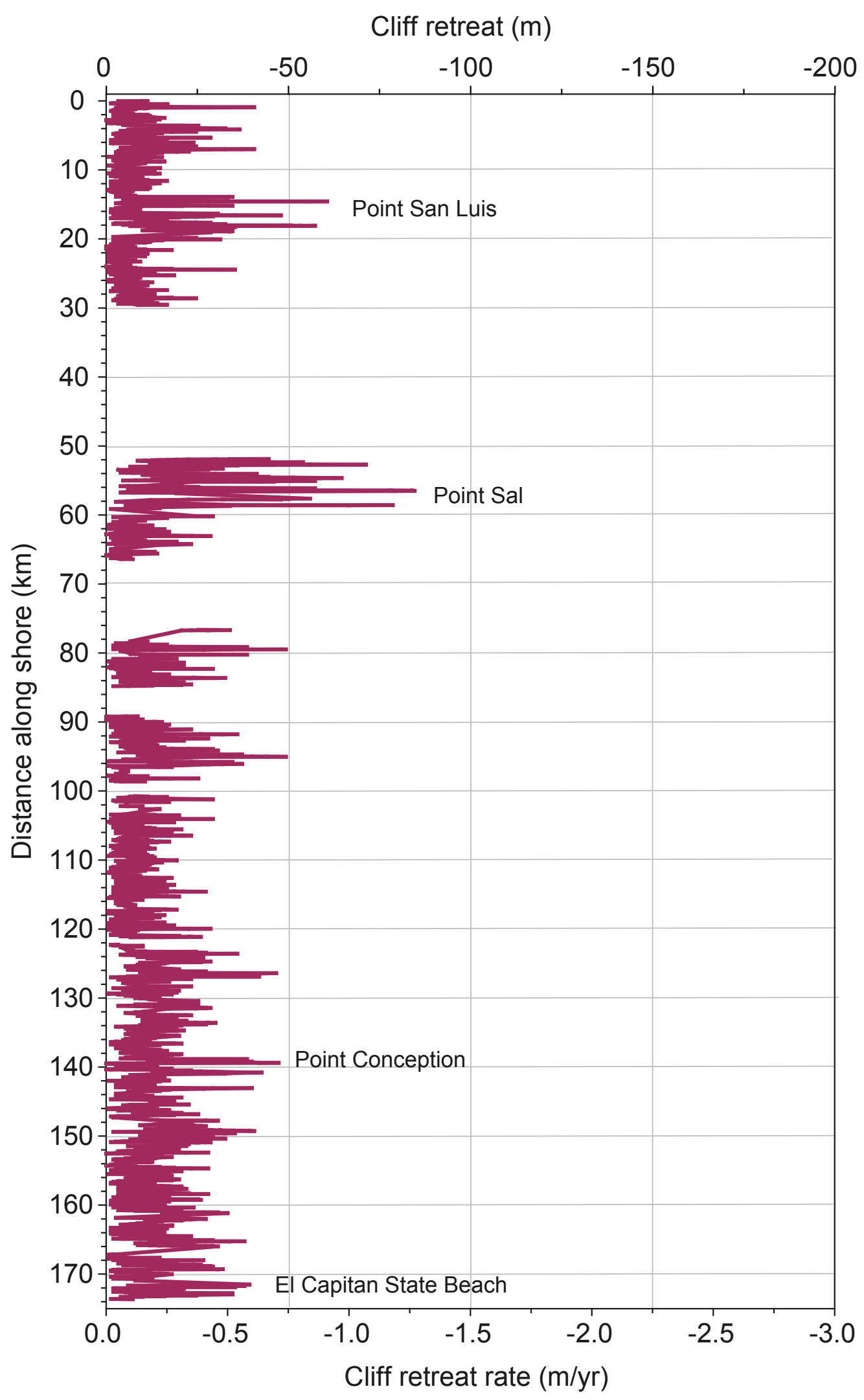

Figure 29. Cliff retreat rates and spatial distribution of rates for the Santa Barbara North region (see Figures 9 and 10B for reference). 


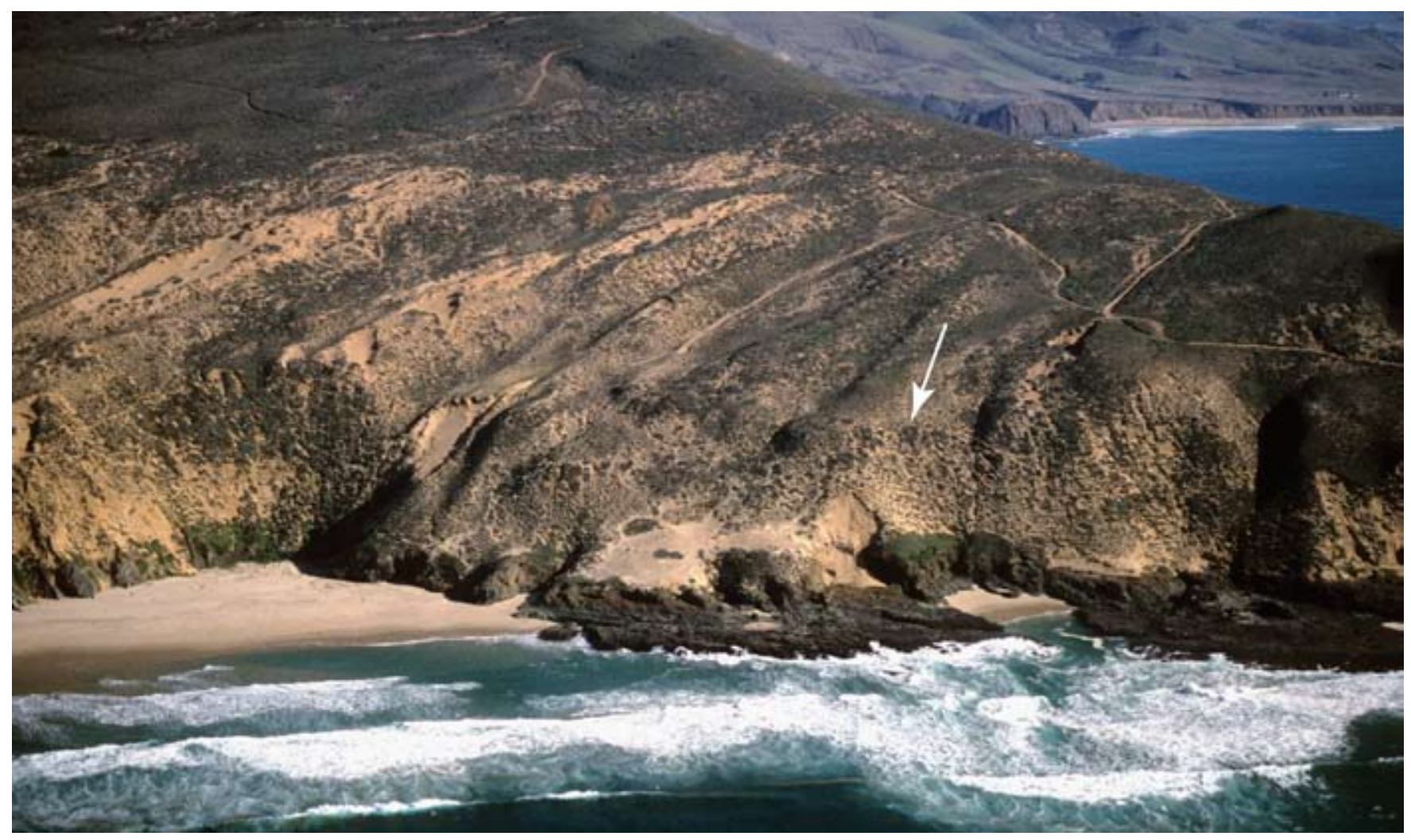

Figure 30. Bluffs formed in Quaternary sands at Point Sal (Figure 10B) had the highest retreat rates in the Santa Barbara North region, and the 70 -year retreat at this location was $-81.3 \mathrm{~m}$. The sands overlie basaltic bedrock (dark material at base of bluff). The vegetated cliff face in this 2005 photograph suggests that the erosion has slowed, at least in the seven years between the end of the study (1998) and the date of the photograph. The arrow point to the cliff edge. (Photo copyright (c) 2002-2007 Kenneth \& Gabrielle Adelman, California Coastal Records Project, www.californiacoastline.org). 


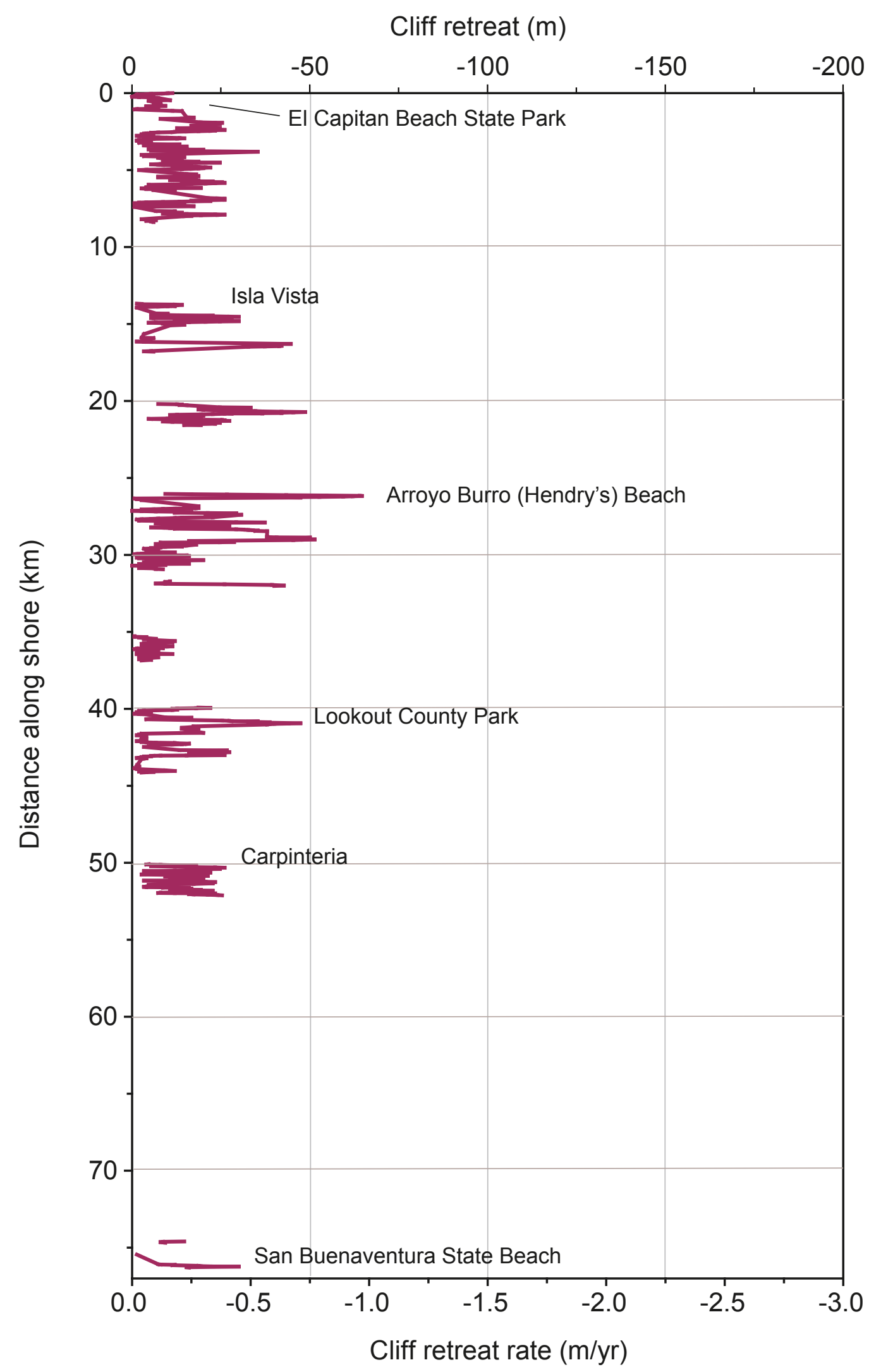

Figure 31. Cliff retreat rates and spatial distribution of rates for the Santa Barbara South region (see Figures 9 and $10 \mathrm{C}$ for reference). 

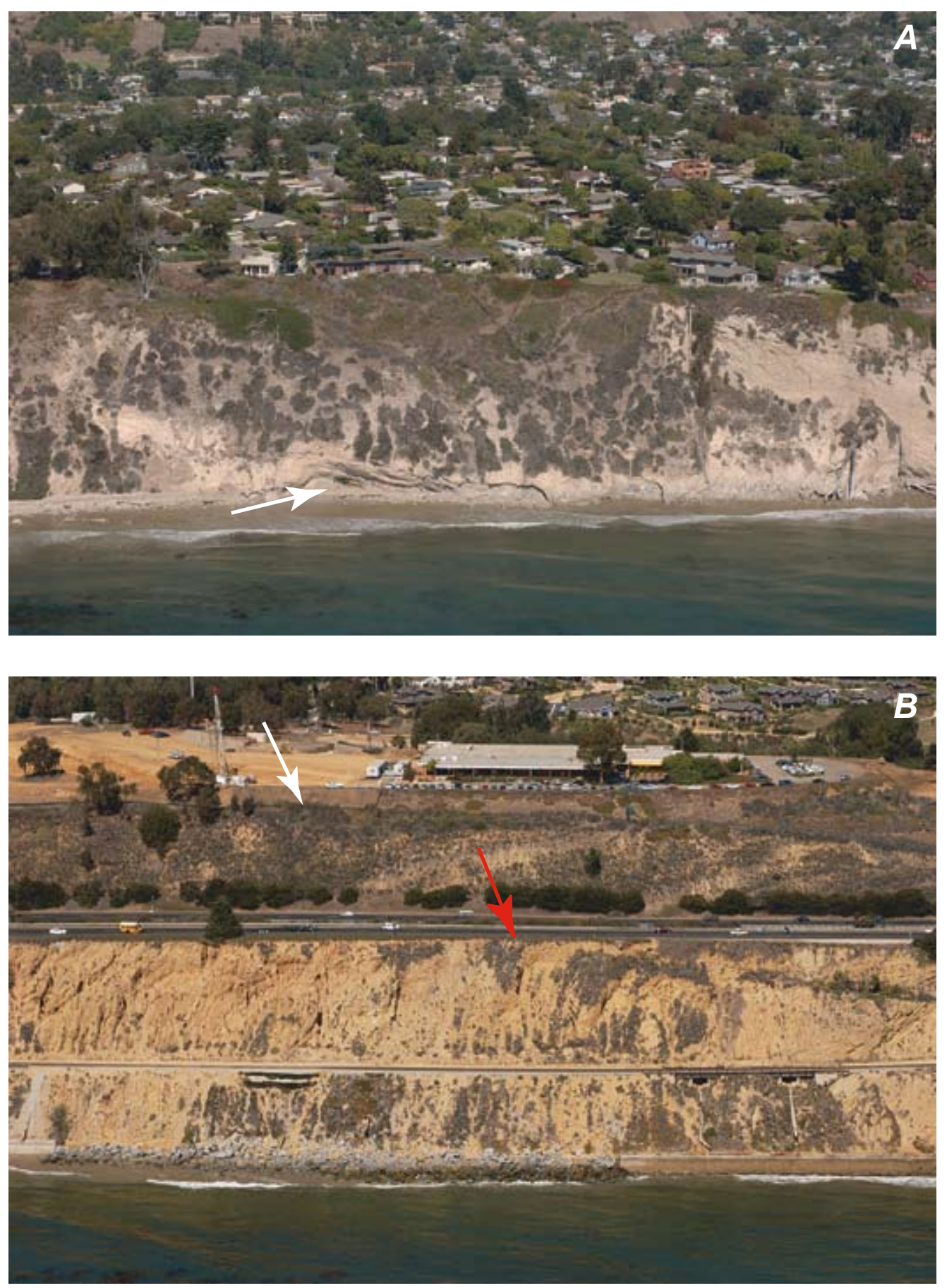

Figure 32. A) The cliffs at Arroyo Burro (Hendry's) Beach have the highest erosion rates in the Santa Barbara South region and the maximum amount of retreat of 70 years was $63 \mathrm{~m}$. Notching at the base of the bluffs is clearly visible in this photo and is indicated by the arrow; and B) rapidly eroding cliffs along Lookout County Beach are armored at the base with riprap to protect both a railroad grade and a road grade. The actual natural bluff edge is above the road grade (white arrow), but the active edge, which is the road grade in this case (red arrow), was used to measure retreat. The cliffs at this location have eroded nearly $50 \mathrm{~m}$ over the 70-year time period of this study. (Photos copyright (c) 2002-2007 Kenneth \& Gabrielle Adelman, California Coastal Records Project, www. californiacoastline.org). 


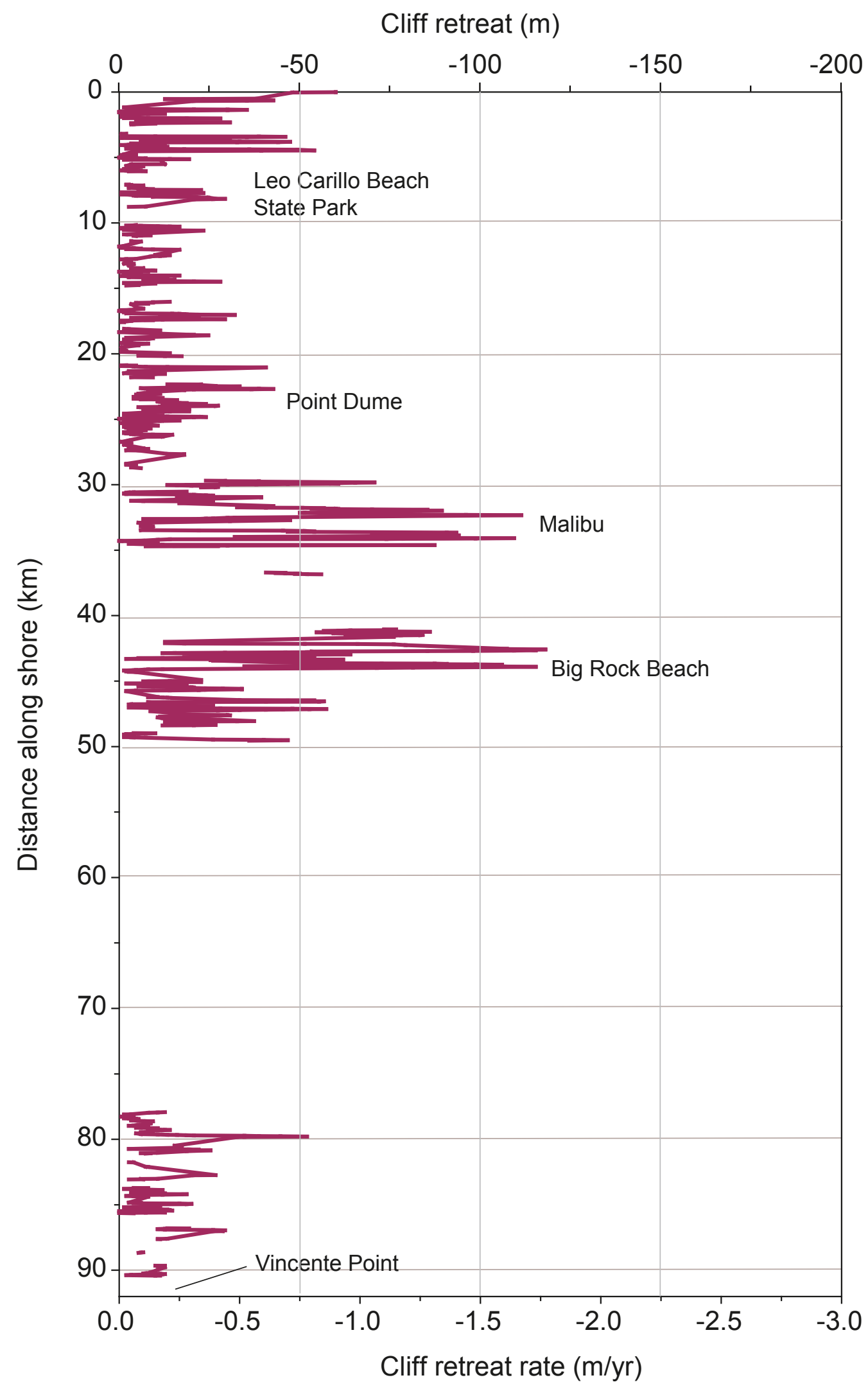

Figure 33. Cliff retreat rates and spatial distribution of rates for the Santa Monica region (see Figures 9 and $10 \mathrm{C}$ for reference). 


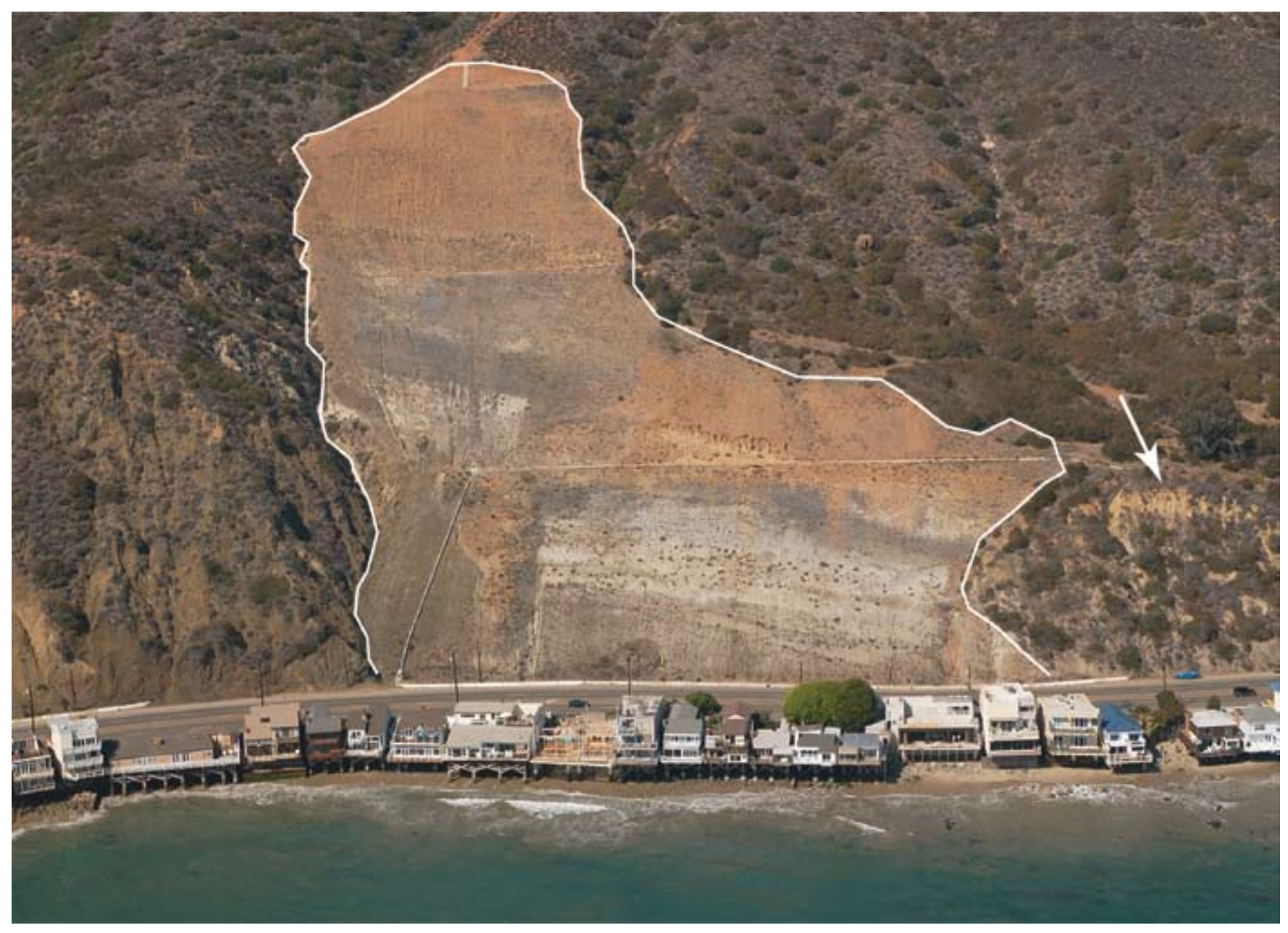

Figure 34. The highest cliff retreat in the Santa Monica region was $-115 \mathrm{~m}$, measured here at the measured at the site of the Big Rock landslide, which began moving rapidly in 1979. The white line demarcates the stabilized portion of the slope, and the arrow indicates the slope break used to measure cliff retreat (Photo copyright (c) 2002-2007 Kenneth \& Gabrielle Adelman, California Coastal Records Project, www.californiacoastline.org). 


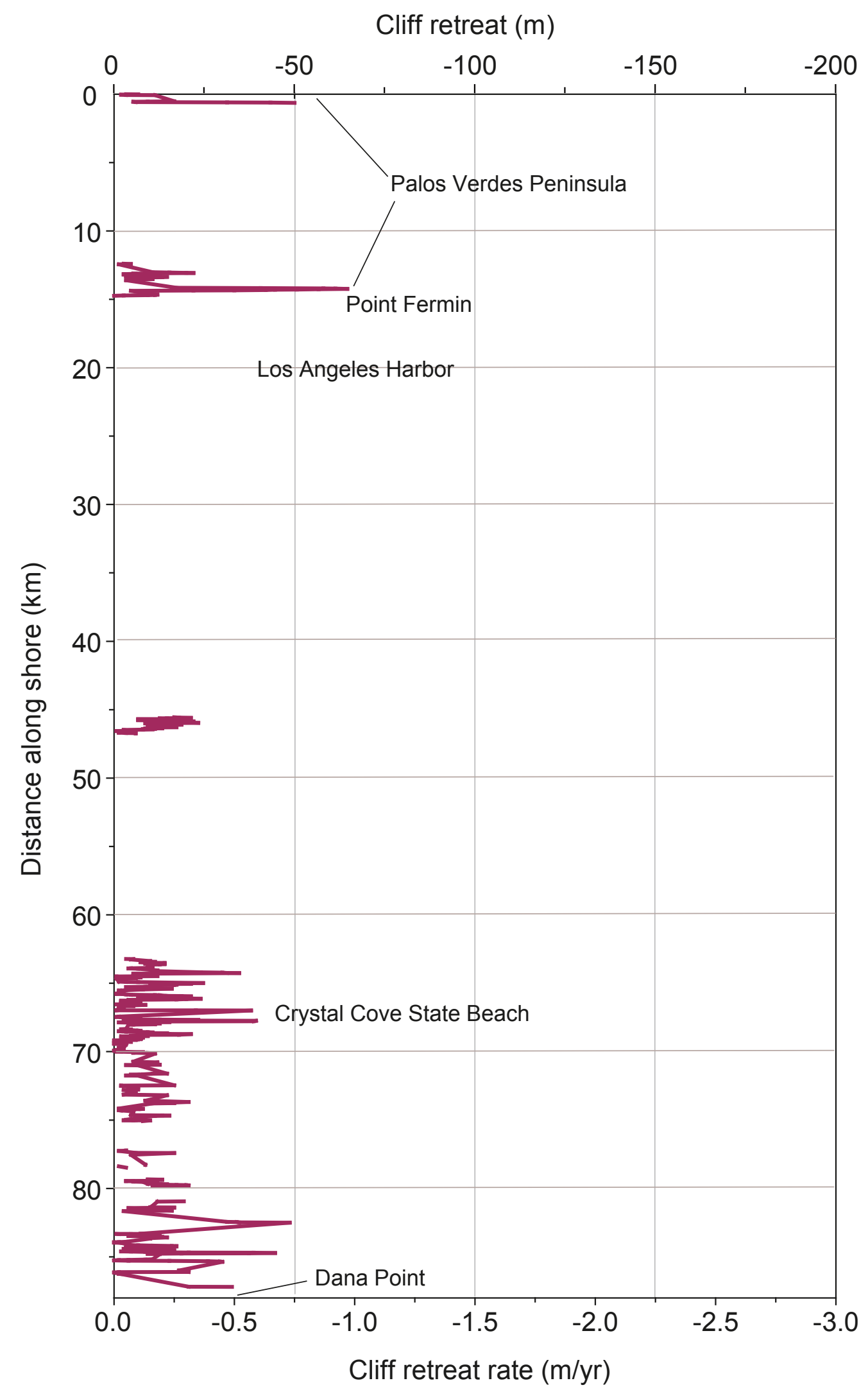

Figure 35. Cliff retreat rates and spatial distribution of rates for the San Pedro region (see Figures 9 and $10 \mathrm{C}$ for reference). 


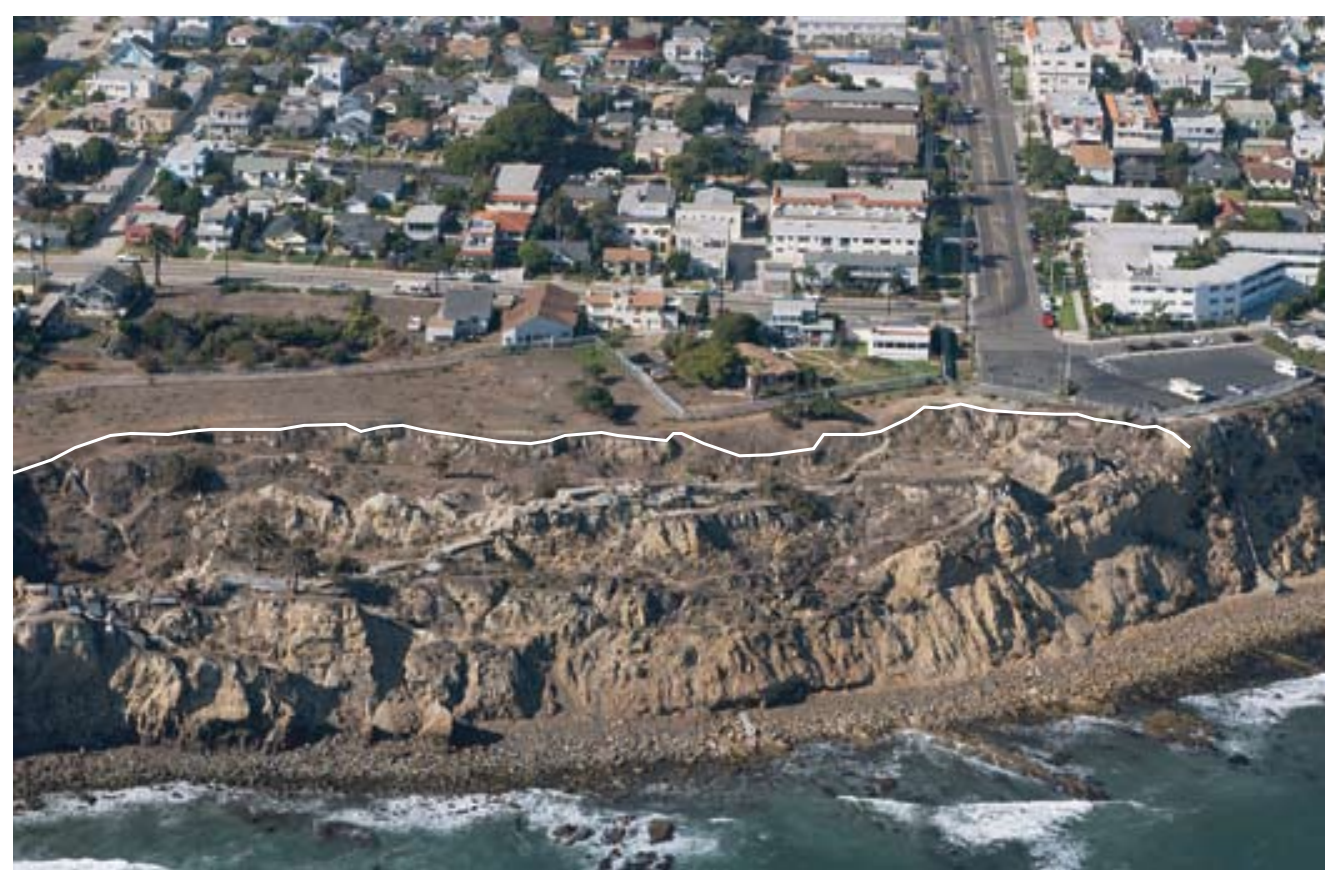

Figure 36. The highest retreat rates in the San Pedro region were measured at the site of the Sunken City landslide at Point Fermin, where the cliff edge has retreated $64 \mathrm{~m}$ in a 70 -year time period. The white line demarcates the approximate location of the head scarp of the landslide. (Photo copyright (c) 2002-2007 Kenneth \& Gabrielle Adelman, California Coastal Records Project, www.californiacoastline.org). 


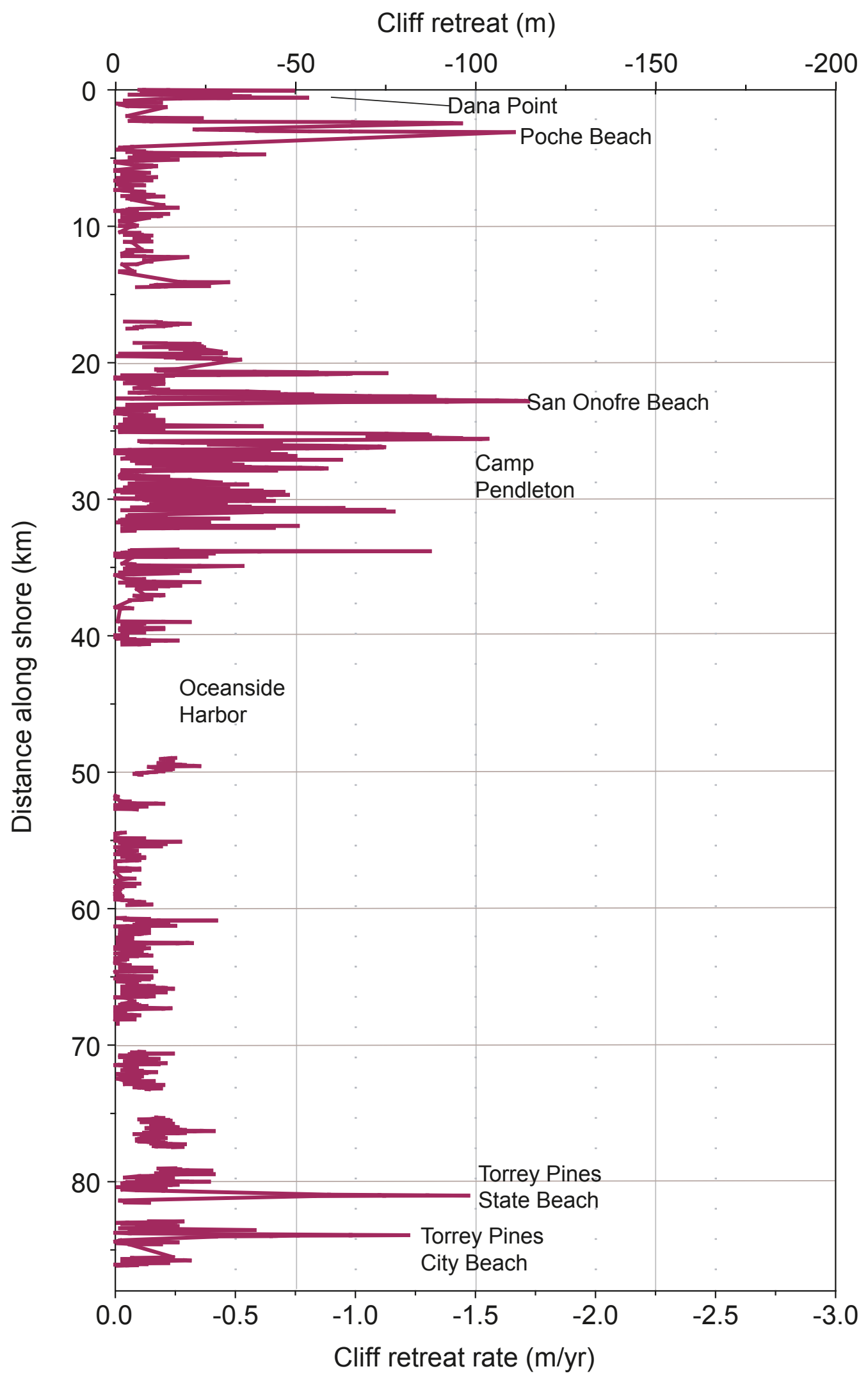

Figure 37. Cliff retreat rates and spatial distribution of rates for the 0 ceanside region (see Figures 9 and $10 \mathrm{C}$ for reference). 

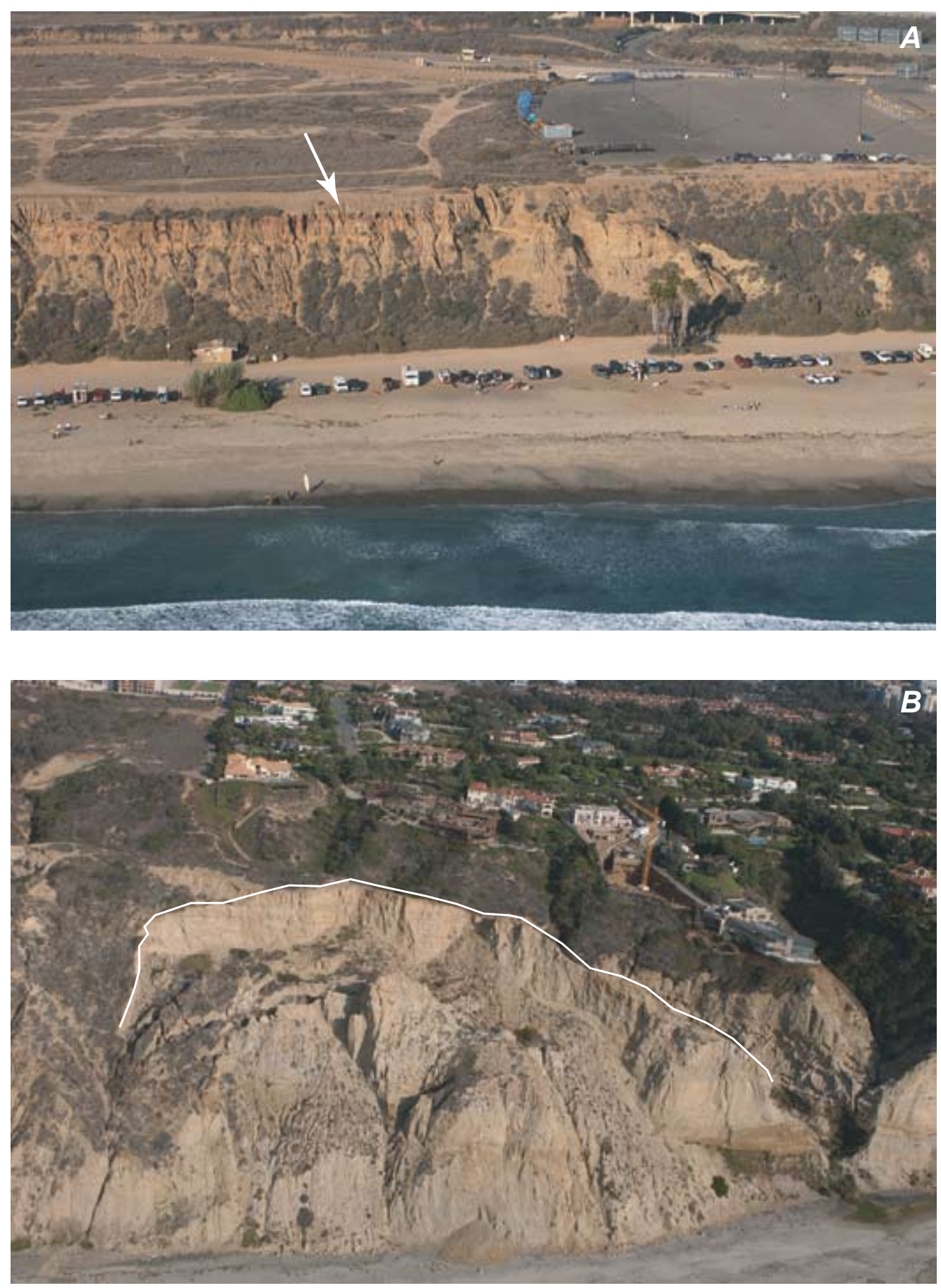

Figure 38. A) The cliffs at San Onofre Beach (locally known as Old Man's) have the highest erosion rates in the Oceanside region, and B) The cliffs at Torrey Pines City Beach have eroded nearly 100 $\mathrm{m}$ during the 70-year period of this study. The white line outlines the active scarp along which the cliffs are slumping at this location. (Photos copyright (c) 2002-2007 Kenneth \& Gabrielle Adelman, California Coastal Records Project, www.californiacoastline.org). 


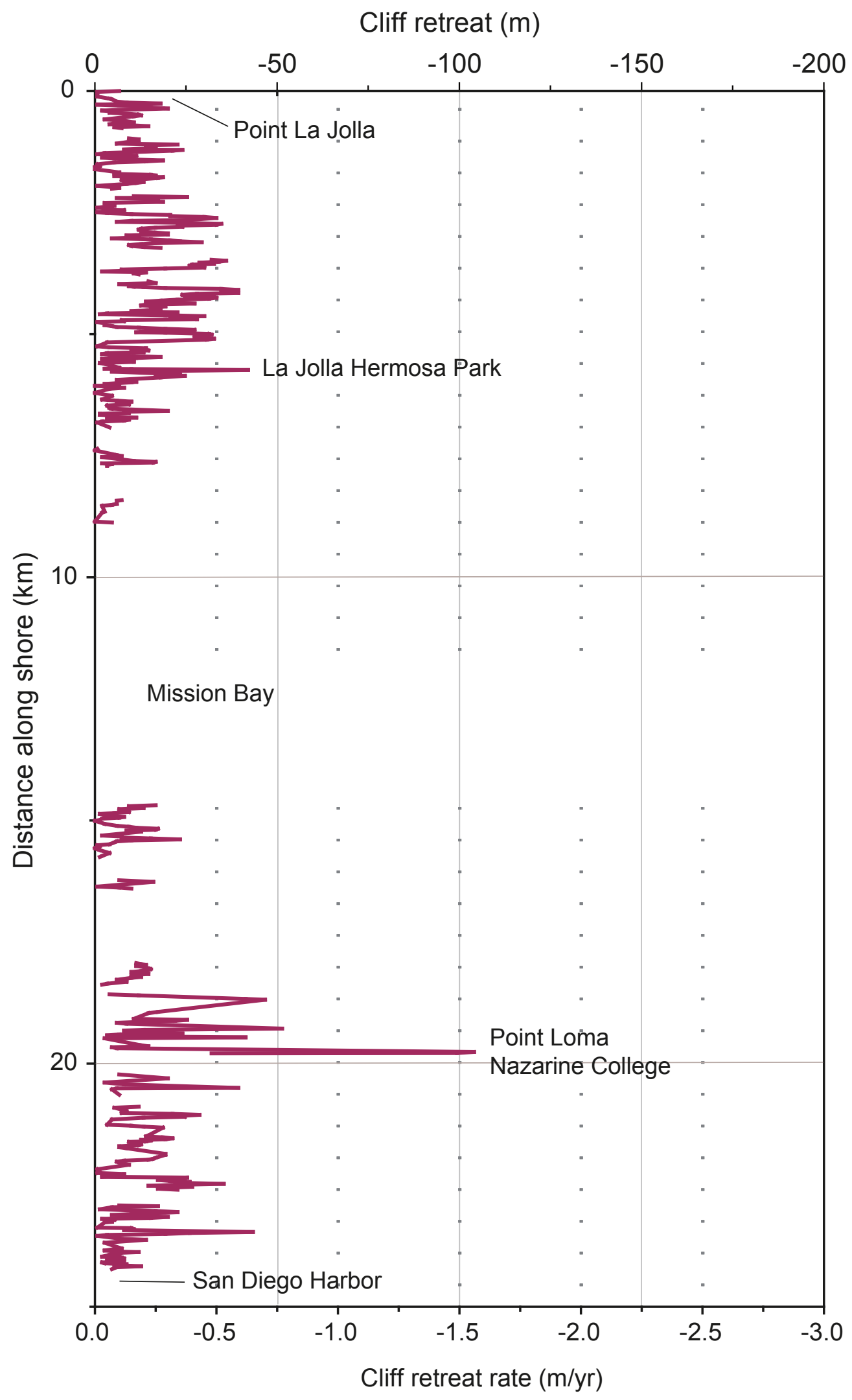

Figure 39. Cliff retreat rates and spatial distribution of rates for the San Diego region (see Figures 9 and $10 \mathrm{C}$ for reference). 


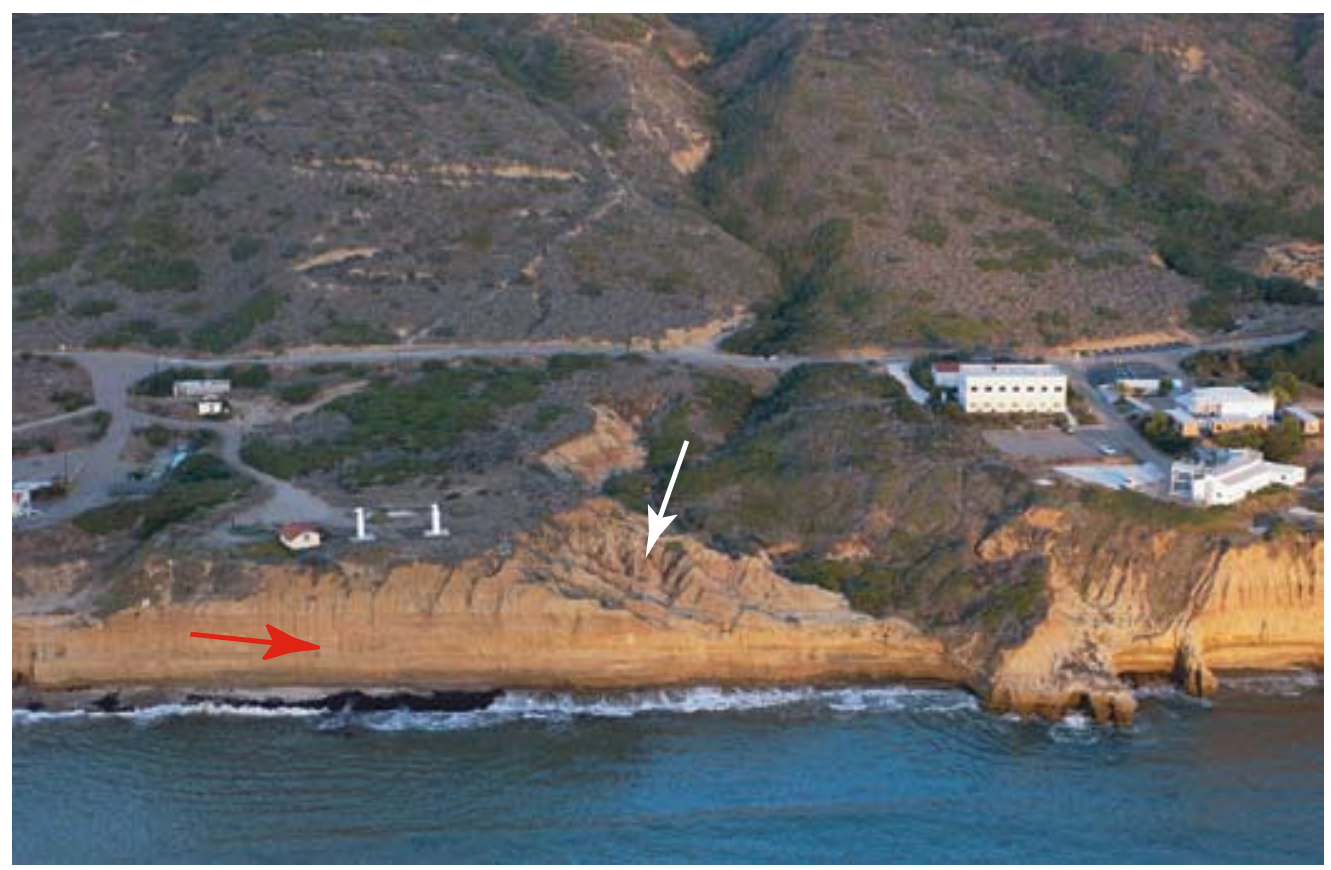

Figure 40. The maximum cliff retreat $(-100 \mathrm{~m})$ and the highest retreat rate $(-1.6 \mathrm{~m} / \mathrm{yr})$ in the San Diego region were measured at the site of the Point Loma Nazarine College. Along this section of coast, the rocks at the cliff base are more resistant to wave attack (red arrow) and the unlithified upper cliff materials are rapidly eroding through processes of gully and rill formation (whiter arrow). (Photo copyright (c) 2002-2007 Kenneth \& Gabrielle Adelman, California Coastal Records Project, www.californiacoastline.org). 


\section{REFERENCES}

Aalto, K.R., 1989, Geology of Patrick’s Point State Park, Humboldt County, California Geology, v. 42, p. 125-133.

Allen, J.C. and Komar, P.D., 2000, Long-term and climaterelated increases in storm wave heights in the North Pacific, EOS, v.81, no.47, p.561, 566-567.

Anders, F.J., and Byrnes, M.R., 1991, Accuracy of shoreline change rates as determined from maps and aerial photographs: Shore and Beach, v. 59, p. 17-26.

Benumof, B.T., Storlazzi, C.D., Seymour, R.J., and Griggs, G.B. 2000, The relationship between incident wave energy and seacliff erosion rates: San Diego County, California: Journal of Coastal Research, v. 16, n. 4, p. 1162-1178.

California Department of Boating and Waterways and State Coastal Conservancy, 2002, California Beach Restoration Study, 280 pp.

California Geological Survey, 2002, Generalized Geologic Map of California: CGS Note \#17, 4 pp.

Collins, B.D. and Sitar, N., 2004, Application of High Resolution 3D Laser Scanning to Slope Stability Studies: Proceedings of the 39th Symposium on Engineering Geology and Geotechnical Engineering, Butte, Montana, May 18-21, 2004, p. 79-92.

Crowell, M., Leatherman, S.P., and Buckley, M.K., 1991, Historical shoreline change; Error analysis and mapping accuracy: Journal of Coastal Research, v. 7, p. 839-852.

Dolan, R., Anders, F. and Kimball, S., 1985, Coastal erosion and accretion, In National Atlas of the United States of America, U.S. Geological Survey, Reston, VA.

Elko, N., A. Sallenger, K. Guy, H. Stockdon, and K. Morgan, 2002, Barrier island elevations relevant to potential storm impacts: 1. Techniques, USGS Open-File Report 2002-287, 1 sheet.

Emery, K.O. and Kuhn, G.G., 1982, Sea cliffs - their processes, profiles, and classification: Geological Society of America Bulletin, v. 93, p. 644-654.

Flick, R.E., 2005, Dana Point to the International Border, In Living with the Changing California Coast, G. Griggs and K. Patsch (eds.), University of California Press, Berkeley, p. 474-512.

Graham, N.E. and Diaz, H.F., 2001, Evidence for intensification of North Pacific winter cyclones since 1948: Bulletin of the American Meteorological Society, v.82, p.1869-1893.
Griggs, G.B. and Patsch, K., 2004, California's coastal cliffs and bluffs, In M.A. Hampton and G.B. Griggs (eds.), Formation, Evolution, and Stability of Coastal Cliffs - Status and Trends: U.S. Geological Survey Professional Paper 1693, p. 53-64.

Griggs G.B., Patsch, K., and Savoy, L., 2005, Understanding the shoreline: In Living with the Changing California Coast, G. Griggs and K. Patsch (eds.), University of California Press, Berkeley, 551 pp.

Griggs, G.B. and Savoy, L.E., 1985, Living With the California Coast: Duke University Press, Durham, North Carolina, 393 pp.

Griggs, G., Weber, J., Lajoie, K. and Mathieson, S., 2005b, San Francisco to Ano Nuevo: In Living with the Changing California Coast, G. Griggs and K. Patsch (eds.), University of California Press, Berkeley, $551 \mathrm{pp}$.

Hampton, Monty A., and Griggs, Gary B., 2004, Formation, evolution, and stability of coastal cliffs- status and trends: U.S. Geological Survey Professional Paper 1693, 123 p.

Hapke, C., 2004, The Measurement and Interpretation of Coastal Cliff and Bluff Retreat, In Hampton, M. and Griggs, G. (eds.), Formation, Evolution, and Stability of Coastal Cliffs - Status and Trends, U.S. Geological Survey Professional Paper 1693. p. 39-50.

Hapke, C.J., 2005, Estimated material yield from coastal landslides based on historical digital terrain modeling, Big Sur, California: Earth Surface Processes and Landforms, v. 30, p. 679-697.

Hapke, C.J. and Green, K.R., 2004, Map showing coastal cliff retreat rates along the Big Sur coast, Monterey and San Luis Obispo Counties, California: U.S. Geological Survey Scientific Investigations Map 2853.

Hapke, C.J. and Green, Krystal, 2006, Coastal Landslide Material Loss Rates Associated with Severe Climatic Events: Geology, v. 34, n. 12, p. 1077-1080.

Hapke, C.J. and Richmond, B.M., 2002, The impact of climatic and seismic events on the short-term evolution of seacliffs based on 3-D mapping -Northern Monterey Bay, California: Marine Geology, v.187, v.3-4, p. 259-278.

Hapke, C., Reid, D., Richmond, B., Ruggiero, P. and List, J., 2006, National Assessment of Shoreline Change Part 3: Historical Shoreline Change and Associated Land Loss Along Sandy Shorelines of the California Coast, U.S. Geological Survey Open-file Report 2006-1219.

Krabill, W., Wright, C., Swift, R., Frederick, E., Manizade, S., Yungel, J., Martin, C., Sontag, J., Duffy, M., Hulslander, W., and Brock, J., 2000. Airborne laser mapping of Assateague National Seashore Beach. Photogrammetric Engineering \& Remote Sensing, v. 66, p. 65-71. 
Moore, L.J., Benumof, B.T., and Griggs, G.B., 1999, Coastal Erosion Hazards in Santa Cruz and San Diego Counties, California: Journal of Coastal Research Special Issue \#28, p. 121-139.

Moore, L.J., 2000, Shoreline mapping techniques: Journal of Coastal Research, v. 16, p. 111-124.

Moore, L.J. and Griggs, G.B., 2002, Long-term cliff retreat and erosion hotspots along the central shores of the Monterey Bay National Marine Sanctuary: Marine Geology, v. 181 , no. $1-3$, p. $265-284$.

Morton, R.A., Miller T.L, and Moore, L.J., 2004, National Assessment of shoreline change: Part 1, Historical shoreline changes and associated coastal land loss along the U.S. Gulf of Mexico, U.S. Geological Survey Open File Report 2004-1043, 44 pp.

Morton, R.A., Miller, T.L., 2005, National Assessment of shoreline Change: Part 2: Historical shoreline change and associated land loss along the U.S. South East Atlantic Coast: U.S. Geological Survey Open-file Report 20051401.

Orme, A.R., 2005, Rincon Point to Santa Monica: In Living with the Changing California Coast, Griggs, Patsch, and Savoy (eds.), University of California Press, Berkeley, CA, p. 394-426.

Plant, N., and Griggs, G.B., 1990a, Coastal landslides caused by the October 17, 1989 earthquake: California Geology, p.75-84.

Plant, N., and Griggs, G.B., 1990b, Coastal landslides and the Loma Prieta earthquake: Earth Science, p.13-17.

Sallenger A.H., Krabill W., Brock J., Swift R., Manizade S., Stockdon H., 2002, Sea-cliff erosion as a function of beach changes and extreme wave runup during the 1997-1998 El Niño: Marine Geology, v. 187, no. 3, pp. 279-297.

Sallenger, A.H., Krabill, W., Swift, R., Brock, J., List, J., Hansen, M., Holman, R.A., Manizade, S., Sontag, J., Meredith, A., Morgan, K., Yunkel, J.K., Frederick, E. and Stockdon, H., 2003. Evaluation of airborne scanning lidar for coastal change applications: Journal of Coastal Research, v.19, p. 125-133.

Savoy, L., Merritts, D. Griggs, G., and Rust, D., 2005a, The Northern California Coast: The Oregon Border to Shelter Cove: In Living with the Changing California Coast, Griggs, Patsch and Savoy (eds.), University of California Press, Berkeley, CA, p. 163-203.

Savoy, L., Merritts, D., Grove, K., and Walker, R., 2005b, Point Arena to San Francisco: In Living with the Changing California Coast, Griggs, Patsch and Savoy (eds.), University of California Press, Berkeley, CA, p. 204-221.
Shalowitz, A.L., 1964, Shore and sea boundaries. Publication 10-1, U.S. Department of Commerce, Washington, DC, 749 pp.

Stockdon, H.F., Sallenger, A.H., List, J.H. and Holman, R.A., 2002, Estimation of shoreline position and change from airborne topographic lidar data. Journal of Coastal Research, v. 18, p. 502-513.

Thieler, E.R., and Danforth, W.W., 1994, Historical shoreline mapping (1). Improving techniques and reducing positioning errors: Journal of Coastal Research, v. 10, p. 549-563.

Thieler, E.R., Himmelstoss, E.A., Zichichi, J.L., and Miller, T.L., 2005, Digital Shoreline Analysis System (DSAS) version 3.0; An ArcGIS@ extension for calculating shoreline change: U.S. Geological Survey Open-File Report 2005-1304.

Thornton, E.B., Sallenger, A.H., Conforto Sesto, J., Egley, L. A., McGee, T., and. Parsons, A.R., 2006, Sand Mining Impacts on Long-Term Dune Erosion in Southern Monterey Bay, Marine Geology, v. 229, n. 1-2, p. 45-58.

U.S. Army Corps of Engineers (USACE), 1971, National Shoreline Study, California Regional Inventory, 106 pp.

Young, A.P. and Ashford, S.A., 2006, Application of Airborne LIDAR for Seacliff Volumetric Change and Beach-Sediment Budget Contributions: Journal of Coastal Research, v. 22, n. 2, p. 307-318. 